Portland State University

PDXScholar

\title{
Evidence for the Eutrophication of Selected Coastal Dunal Lakes: Historical Comparison of Indices for Nutrient Enrichment
}

Steven Gregory Dagget

Portland State University

Follow this and additional works at: https://pdxscholar.library.pdx.edu/open_access_etds

Part of the Biology Commons

Let us know how access to this document benefits you.

Recommended Citation

Dagget, Steven Gregory, "Evidence for the Eutrophication of Selected Coastal Dunal Lakes: Historical Comparison of Indices for Nutrient Enrichment" (1994). Dissertations and Theses. Paper 4723.

https://doi.org/10.15760/etd.6607

This Thesis is brought to you for free and open access. It has been accepted for inclusion in Dissertations and Theses by an authorized administrator of PDXScholar. Please contact us if we can make this document more accessible: pdxscholar@pdx.edu. 
The abstract and thesis of Steven Gregory Daggett for the Master of Science in Biology were presented April 26, 1994, and accepted by the thesis committee and the department. COMMITTEE APPROVALS:

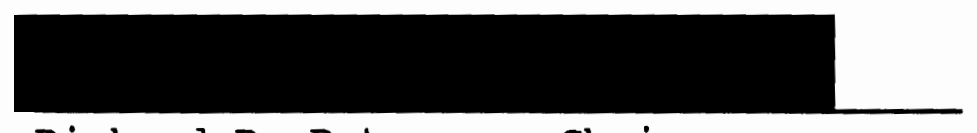

Richard R. Petersen, Chair
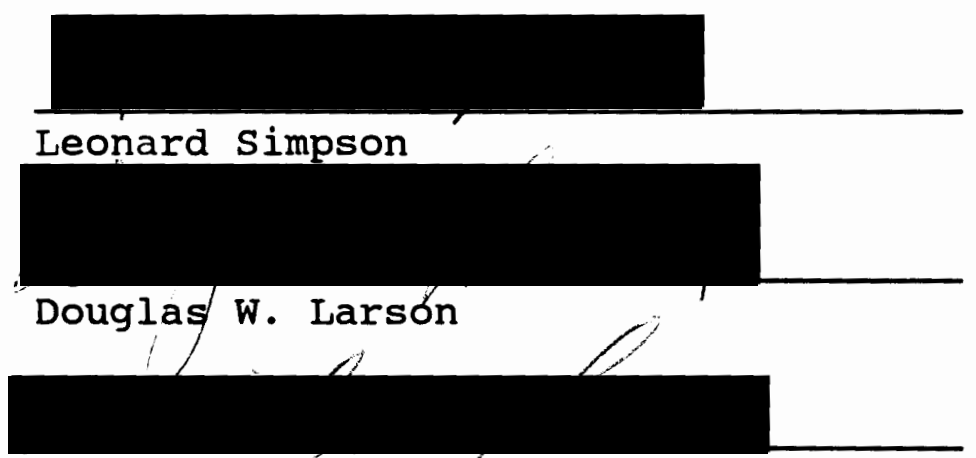

Daniel M. Johnson

Representative of the office of Graduate Studies

DEPARTMENTAL APPROVAL:

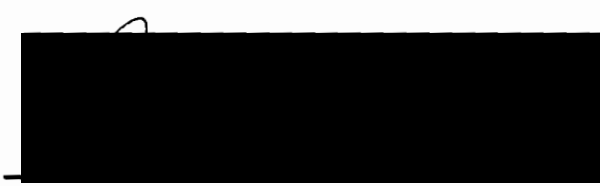

Robert Tinnin, Chair

Department of Biology

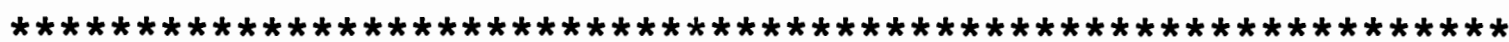

ACCEPTED FOR PORTLAND STATE UNIVERSITY BY THE LIBRARY

by

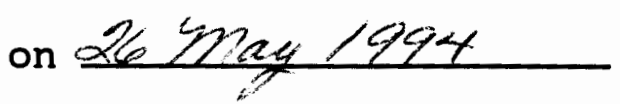


AN ABSTRACT OF THE THESIS OF steven Gregory Daggett for the Master of Science in Biology presented April 22, 1994.

Title: Evidence for the eutrophication of selected coastal dunal lakes: historical comparison of indices for nutrient enrichment.

Three coastal Oregon dunal lakes, Mercer Lake, Munsel Lake, and Woahink Lake, were studied in an effort to determine if eutrophication has occurred since initial studies were conducted in 1938 and to determine each lake's current trophic status. Data collected in 1991 and 1992 for phytoplankton primary productivity; chlorophyll a ; phytoplankton species, biovolumes, and densities; nutrients; optical characteristics; and dissolved oxygen were compared with historical data sets. Additional data for zooplankton, benthic invertebrates, and other relevant limnological data were used to more completely characterize each lake. Phytoplankton primary productivity measurements indicate that biological productivity has increased at each lake since 1969-1971. Chlorophyll a concentrations appear to have increased only at Mercer Lake. Other limnological data are insufficient to determine if and to what extent these lakes have eutrophicated. Based on data collected in 1991 and 1992, the current trophic state of each lake can be 
described as follows: Mercer Lake is mesotrophic to eutrophic but closer to mesotrophic, Munsel Lake is oligotrophic to mesotrophic but closer to mesotrophic, and Woahink Lake is oligotrophic to mesotrophic but closer to oligotrophic. 


\begin{abstract}
EVIDENCE FOR THE
EUTROPHICATION OF SELECTED COASTAL DUNAL LAKES:

HISTORICAL COMPARISON OF INDICES FOR NUTRIENT ENRICHMENT
\end{abstract}

by

STEVEN GREGORY DAGGETT

A thesis submitted in partial fulfillment of the requirements for the degree of

\author{
MASTER OF SCIENCE \\ in \\ BIOLOGY
}

Portland State University

1994 
This thesis is dedicated to my wife Amy Kent, my son William, and to the memory of my son Taylor. 


\section{ACKNOWLEDGEMENTS}

I would like to thank Dr. Richard Petersen for encouraging me to pursue a Masters Degree in Biology, introducing me to the mysteries of lakes, and arranging for the research assistantship which eventually brought me to the study of these three lakes.

Special thanks to thank Dr. Douglas Larson who encouraged me to undertake this specific study. Dr. Iarson has worked at these three lakes since 1970 and graciously supplied unpublished data and samples that he and John Salinas gathered during the summer and fall of 1991.

Allen Vogel and Jim Sweet freely shared their expertise with zooplankton and phytoplankton, respectively. Rick Hafele at the DEQ Lab helped me with the taxonomy of benthic invertebrates.

Thanks also to my field help: my friend Brad Robinson, Bob Anderson at Woahink Lake, and Al Burhans and Roy Fisher at Munsel Lake.

Amy Kent, the members of my committee, and Dr. Ed Lippert all provided valuable editing suggestions.

The Oregon Department of Environmental Quality, through the efforts of Andy Schaedel, provided funding for the analyses of the phytoplankton, zooplankton, and benthic invertebrate samples. 
TABLE OF CONTENTS

PAGE

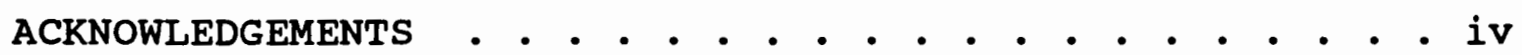

LIST OF TABLES • . . . . . . . . . . . . . . . . . . vii

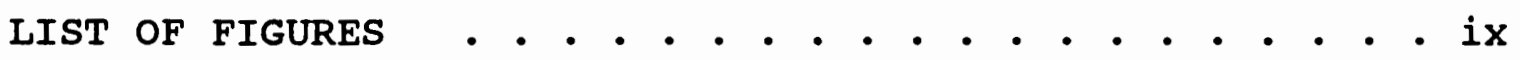

INTRODUCTION . . . . . . . . . . . . . . . . . . . . 1

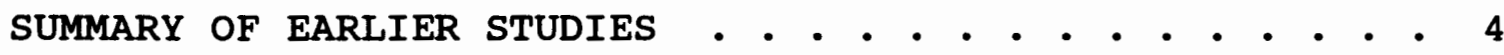

Physical setting . . . . . . . . . . . . . . 4

Geography

Geology

Hydrology

Climate

Vegetation

Limnological Background . . . . . . . . . . . 11

Physical Description

Summary of Earlier Limnological studies

MATERIALS AND METHODS . . . . . . . . . . . . . . . . 21

Larson and Salinas Methods . . . . . . . . . 21

Daggett and Petersen Methods . . . . . . . . . 23

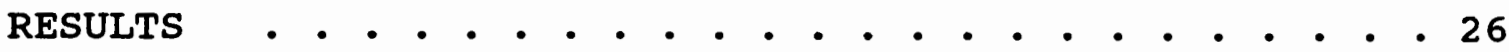

Temperature and Dissolved Oxygen . . . . . . . . 26

Optical Characteristics . . . . . . . . . . 30

Nutrients . . . . . . . . . . . . . . . . . 34

Primary Productivity . . . . . . . . . . . . 39

Chlorophyll a . . . . . . . . . . . . . . . 41 
Phytoplankton . . . . . . . . . . . . . 45

Mercer Lake Phytoplankton

Munsel Lake Phytoplankton

Woahink Lake Phytoplankton

Zooplankton . . . . . . . . . . . . 69

Mercer Lake Zooplankton

Munsel Lake Zooplankton

Woahink Lake Zooplankton

Benthic Invertebrates . . . . . . . . . . 80

Mercer Lake Benthic Invertebrates

Munsel Lake Benthic Invertebrates

Woahink Lake Benthic Invertebrates

SUMMARY AND DISCUSSION • • . . • . . . • • • 85

Current Trophic Status . . . . . . . . . 85

Evidence for Eutrophication . . . . . . . 87

Mercer Lake

Munsel Lake

Woahink Lake

REFERENCES

APPENDICES

A Methods for Analysis of Primary

Productivity, Chlorophyll a ,

Phytoplankton, and Zooplankton . . . . . . 99

B Optical Characteristics . . . . . . . . 107

c Nutrients . . . . . . . . . . . 113

D Phytoplankton Species List . . . . . . . 115

E Phytoplankton Biovolumes and Densities . . . 118

F Zooplankton . . . . . . . . . . . . 130

G Benthic Invertebrates . . . . . . . . 135

H Compilation of Data Collected

in 1991 and 1992 . . . . . . . . . . . 138 


\section{LIST OF TABLES}

TABLE

PAGE

I Physical Characteristics for Mercer Lake, Munsel Lake, and Woahink Lake . . . . . 13

II Selected Researchers and selected Water

Quality Variables Investigated at

Mercer, Munsel, and Woahink Lakes . . . 17

III Optical Characteristics compared

Between Study Lakes . . . . . . . . 33

IV Summary of Nitrogen and Phosphorus Data

for the Study Lakes . . . . . . . . 35

V Mercer Lake Primary Productivity . . . . . . 39

VI Munsel Lake Primary Productivity . . . . . . 40

VII Woahink Lake Primary Productivity . . . . . . 40

VIII Summary of Total Biovolume Data for

Phytoplankton Samples Collected

Since 1981 . . . . . . . . . . . . 49

IX Comparison of Woahink Lake Phytoplankton

Biovolume and Density Data for

Selected Dates and Depths . . . . . 67

X Summary of Zooplankton Data for

Samples Collected in 1991

at the study Lakes . . . . . . . . . 71 
viii

XI Trophic state Categories and water

Quality Parameters . . . . . . . 85

XII Trophic state Indicators for study

Lakes: Mean and Range of

Selected Variables . . . . . . . 86 


\section{LIST OF FIGURES}

FIGURE

PAGE

1. Map of Oregon Showing Location of

Study Area Near Florence . . . . . . 6

2. Map of Study Area Showing Location of

Study Lakes . . . . . . . . . . . 14

3. Bathymetric Map of Mercer Lake Showing

Location of Sampling stations . . . . . 14

4. Bathymetric Map of Munsel Lake Showing

Location of Sampling stations . . . . 15

5. Bathymetric Map of Woahink Lake Showing

Location of Sampling stations . . . . 16

6. Dissolved Oxygen and Temperature Profiles

Compared for Mercer Lake . . . . . . 28

7. Dissolved Oxygen and Temperature Profiles

Compared for Munsel Lake . . . . . . 29

8. Dissolved Oxygen and Temperature Profiles

Compared for Woahink Lake . . . . . . 30

9. Secchi Disk Depths Measured in

Mercer Lake 1948-1993 . . . . . . . . 31

10. Secchi Disk Depths Measured in

Munsel Lake 1967-1993 . . . . . . . 32

11. Secchi Disk Depths Measured in

Woahink Lake 1947-1993 . . . . . . . 32 
12. Comparison of Chlorophyll a concentrations for Similar Dates over Time at Mercer Lake. . . . . . . . . . 42

13. Comparison of Chlorophyll a Concentrations for Similar Dates over Time at Munsel Lake . . . . . . . . . . 43

14. Comparison of Chlorophyll a Concentrations for similar Dates over Time at Woahink Lake . . . . . . . . . 44

15. Total Biovolume and Total Density for all Phytoplankton Samples collected at Mercer Lake Since 1981 . . . . . 50

16. Biovolume of Mercer Lake Phytoplankton by Phylum • . . . . . . . . . . . 51

17. Trophic Indicator Species in Mercer Lake Phytoplankton Samples as a Percentage of Total Sample Biovolume . . 53

18. Diversity and Evenness Indices Based on Density and Biovolume for Mercer Lake Phytoplankton Samples . . . . . . . 54

19. Total Biovolume and Total Density for all Phytoplankton Samples collected at Munsel Lake Since 1981 . . . . . . 55 20. Biovolume of Munsel Lake Phytoplankton by Phylum • . • . • . . . . • • 56 
21. Trophic Indicator Species in Munsel Lake

Phytoplankton samples as a

Percentage of Total Sample Biovolume . . 59

22. Diversity and Evenness Indices Based on

Density and Biovolume for Munsel Lake

Phytoplankton samples . . . . . . 60

23. Total Biovolume and Total Density for all

Phytoplankton Samples Collected

at Woahink Lake Since 1981 . . . . . 61

24. Biovolume of Woahink Lake Phytoplankton

by Phylum .............. 63

25. Trophic Indicator Species in Woahink Lake

Phytoplankton Samples as a

Percentage of Total Sample Biovolume . . 64

26. Diversity and Evenness Indices Based on

Density and Biovolume for Woahink

Lake Phytoplankton Samples . . . . . 65

27. Total Biovolume by Species Versus Cell

Size for Selected Dates and Depths at Woahink Lake . . . . . . . . 68 


\section{INTRODUCTION}

Mercer Lake, Munsel Lake, and Woahink Lake are coastal sand-dunal lakes clustered around the city of Florence on oregon's central coastline. These lakes, and many others in the area, originated as the combined result of a postglacial rise in sea level and the subsequent impoundment of coastal river valleys by migrating sand dunes. These dunal lakes are thought to be unique in the northern hemisphere because of their range of sizes, large number, great variety, and close physical proximity (Larson 1991).

Limnologists and area residents are concerned that human activities are negatively impacting the water quality of these three lakes. This concern is based on the knowledge that a lake is the ultimate sink for nutrients, sediment, and pollutants generated by human activity in the watershed. The study lakes are situated in an area of unstable soils which are very susceptible to human impacts. In each watershed, activities such as clear-cut logging and public and private development have occurred and will continue to occur. These activities promote erosion by removing vegetation and disturbing soil. Additionally, household and garden activities add nutrients to the soil. The city of Florence and the surrounding area are undergoing rapid development. The development of prime lakefront and 
watershed properties will further disturb each watershed.

Although human activities have altered the lakes' watersheds; their impact on the lakes' water quality is unknown. While eutrophication may occur naturally, it is more often the result of human activities, including those just discussed.

There are two purposes for this current research: (1) determine if and to what extent the lakes are eutrophicating; and (2) provide additional limnological information for each lake. This study reviews historic data and analyzes data collected in 1991 and 1992. The entire data set is evaluated in an attempt to detect water quality changes over time at each lake. The recently collected data is used to estimate each lake's current trophic state. These determinations require a comparative analysis of various limnological properties, particularly those that are indicative of eutrophication. These include phytoplankton primary productivity, phytoplankton species composition and relative abundance, lakewater optical properties, nutrient chemistry, dissolved oxygen profiles, and other trophic indicators. Additionally, zooplankton and benthic invertebrate data are analyzed in an effort to more fully characterize each lake.

These lakes were chosen for the current study primarily because of the availability of data from 1938 through 1992 . The two most recent data sets were collected by Larson and 
Salinas (1991 unpublished) during the summer of 1991 and by this researcher (Daggett and Petersen 1993, 1994) from 1991 to 1993. However, the limnological database is not continuous, rather it is extremely spotty with clumps of data points separated by decades. This makes it impossible to assess water quality trends statistically and allows only speculation about changes based on visual inspection of graphs and tabular data. Additionally, the time periods during which data was collected may not be representative in terms of climate, watershed disturbance, and other factors affecting lake limnology. This inconsistent database underscores the need for long-term data collection to accurately assess eutrophication and its causes. 
SUMMARY OF EARLIER STUDIES

PHYSICAL SETTING

\section{Geography}

Mercer Lake, Munsel Lake, and Woahink Lake are located along the central coastline of oregon and are clustered around the city of Florence (Figure 1). Each lake lies

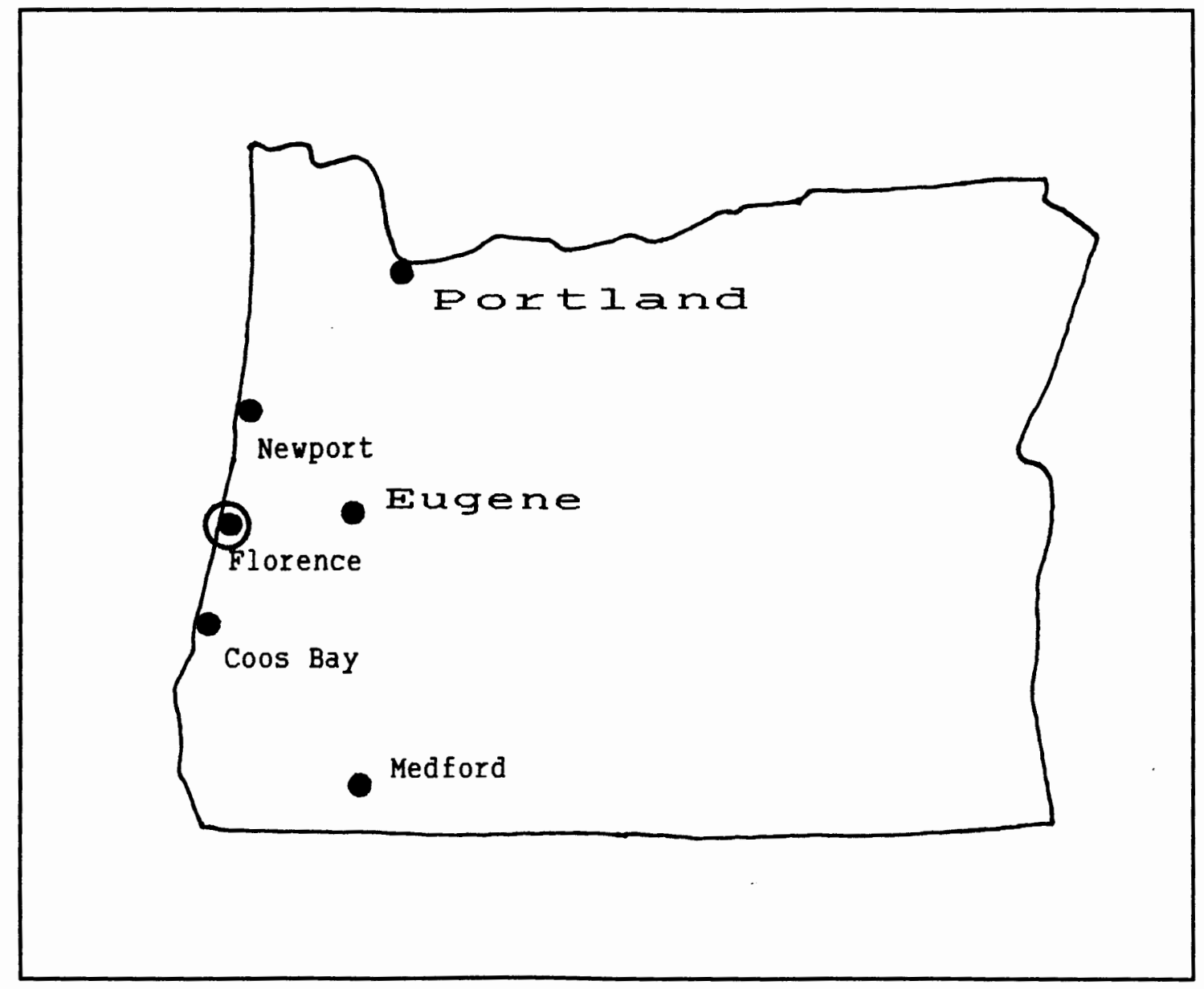

Figure 1. Map of Oregon showing location of study area near Florence. 
east of Highway 101 and within $4.0 \mathrm{~km}$ of the Pacific Ocean. Mercer Lake is located $5.6 \mathrm{~km}$ north of Florence, Munsel Lake is located $1.6 \mathrm{~km}$ north of Florence, and Woahink Lake is located $4.8 \mathrm{~km}$ south of Florence (Figure 2).

\section{Geology}

The study lakes lie near the northern edge of the coos Bay dunal sheet. The dunal sheet extends approximately 50 miles from north to south, bordered to the north by Heceta Head and to the south by Coos Bay, and ranges in width up to $4.8 \mathrm{~km}$. It is bordered to the west by the Pacific Ocean and to the east by the foothills of the Coast Mountain Range. The dunal sheet is approximately 30 to $60 \mathrm{~m}$ thick and has a generally flat topography with an elevation of approximately $24 \mathrm{~m}$ above sea level (Christensen 1982). The sheet represents accumulated wind-blown sand that has been deposited within the last 27,000 years on a section of ancient wave-cut terrace which was warped downward below sea level (Schlicker and Newcomb 1974). The wave cut terrace underlying the dunal sheet is composed of marine sandstones, siltstones, and mudstones of the Eocene Flournoy Formation (Baldwin 1976).

Although the dunal lakes generally share a common origin, they have slight variations in their formation histories. Mercer Lake and Woahink Lake both represent lake basins formed by the submergence of stream valleys during the rise in sea level following the Pleistocene ice age. 


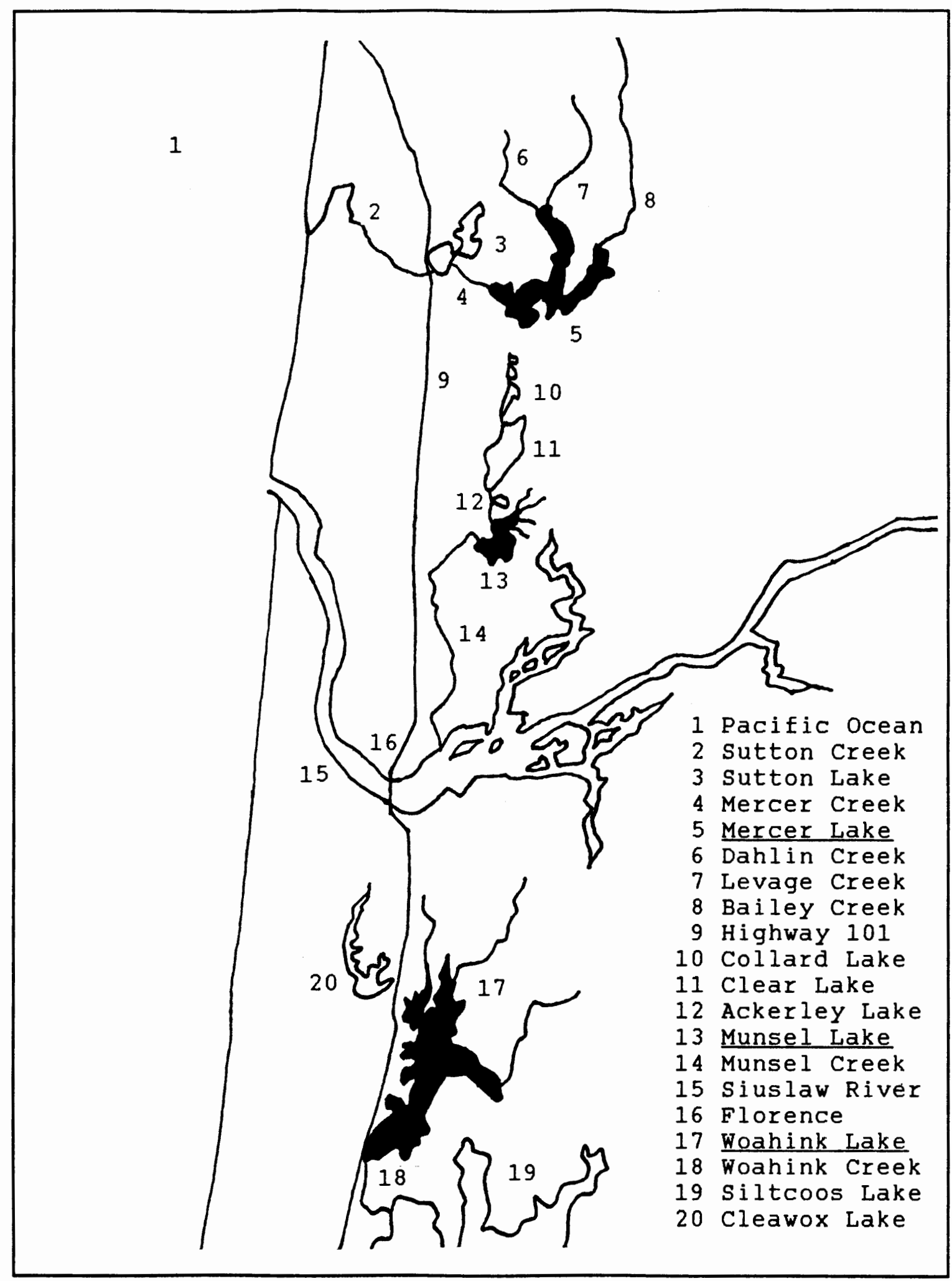

Fiqure 2. Map of study area showing location of study lakes. 
They display the dendritic shape common to lakes with this type of origin. The sand barriers at the mouth of the streams were formed by materials deposited by the stream, longshore ocean currents, wave action, and wind action (Baldwin 1976).

Munsel Lake, on the other hand, lies on the eastern edge of the dunal sheet and is essentially a depression between the eastward migrating sand dunes and the Flournoy bedrock. These types of depressions result from the wind's decreasing ability to carry sand as the migrating dunes approach the coast Range. Most of the sand is deposited on the west, or windward, side of the dune, leaving a trough or depression between the dune and the coast Range. The basin then filled with water brought by surface runoff and groundwater intrusion (Christensen 1982). The western edges of both Munsel Lake and Woahink Lake are partially bordered by migrating sand dunes. The remaining shoreline of those lakes, and the entire shoreline of Mercer Lake, is bordered by trees and shrubs.

\section{Hydrology}

In the Florence area, the largest body of freshwater is present in the form of groundwater contained in a sand aquifer. The shape of the water table approximates the surface topography. In some places the water table lies above the surface of the land, but generally, the depth to the top of the water table ranges between $2 \mathrm{~m}$ and $10 \mathrm{~m}$. The 
ground water is of good chemical quality except for generally low pH and slightly excess amounts of dissolved iron (Schlicker 1974). It has been estimated that about $75 \%$ of the mean annual precipitation reaches the ground water. Typically, the highest ground water storage occurs in February or March and the lowest occurs in september or october. Schlicker (1974) suggested that, in the case of Munsel Lake, groundwater recharge from the lake is insignificant. Groundwater turnover time, or replacement time, in the highly permeable portion of the aquifer is estimated at 30 years based on tritium age dating analysis (Christensen 1982).

The general direction of groundwater movement is downhill, toward the west. Therefore, only a minor amount moves toward the lakes on the east side of the dunal sheet. Schlicker (1974) proposed that any lowering of the water table might remove the groundwater containment of lakes north of the Siuslaw River, including Mercer Lake and Munsel Lake, but would have little effect on lakes south of the Siuslaw River, such as Woahink Lake and Siltcoos Lake, where impermeable material is responsible for lake containment.

All of the lakes are partially fed and drained by surface streams. Mercer Lake has three tributaries -Bailey Creek, Levage Creek, and Dahlin Creek -- which enter the lake from the north. The lake's outlet, Mercer creek, flows northwestward into sutton Lake which is connected to 
the ocean via sutton creek. Stream surveys conducted in 1959 showed that all of Mercer Lake's tributary streams supported spawning populations of anadromous fish (Oakley 1962a).

Munsel Lake is the southernmost lake in a series of four connected lakes. From north to south, the lakes are Collard Lake, Clear Lake, Ackerley Lake, and Munsel Lake. In addition to Ackerley Creek, Munsel Lake is fed from the east by four small unnamed tributaries. No spawning by anadromous fish was noted during stream surveys (Oakley 1962b). Munsel creek flows south out of the lake and enters the Siuslaw River east of Florence.

Woahink Lake is fed by three unnamed tributaries that enter the lake: two from the north and one from the east. stream surveys noted that the tributary stream entering from the east was the primary spawning area for coho salmon utilizing the lake (McGie and Breuser 1962). Woahink Creek flows out of the lake to the south and into siltcoos Lake which is connected to the ocean by the siltcoos River.

\section{Climate}

The study area lies in a mild and wet marine climate. The existence of seasonal contrasts for temperature and precipitation are caused by the study area's location near the 45th parallel. Mean summer temperatures, peaking in August, are higher than mean winter temperatures because of the long summer days and increased direct solar exposure. 
The temperature extremes of both seasons are moderated by the seasonal temperature lag of marine waters and the seasonal atmospheric circulation (Jackson 1985). The mean annual precipitation at Florence is 1.75 meters. of this total rainfall, $80 \%$ occurs between October and March as a result of cyclonic storms that originate over the Pacific Ocean and move onshore (Christensen 1982).

Atmospheric circulation is also responsible for the seasonal patterns of wind along the oregon coast. Summer windflows are generally from the northwest, being caused by the presence of areas of high pressure in the northeast Pacific. Winter winds blow predominantly from the southwest, paralleling the pressure gradients between subtropical areas of high pressure and low pressure systems in the north Pacific (Jackson 1985). Summer winds are generally moderate and steady while winter winds are generally strong and intermittent. The prevailing west winds drive the sand dunes in a generally easterly direction. On the far northern part of the dunal sheet, near Heceta Head, topography interrupts the windflow and causes the dunes to move toward the southeast. over the remainder of the dunal sheet, the dominant direction of dunal movement is toward the northeast in response to the predominant southwest winter winds (Christensen 1982).

\section{Vegetation}

As defined by vegetation zones, the study area lies in 
the Sitka Spruce Zone of the Forest Province. This zone is confined to the coast and is characterized by the dominance of sitka spruce (Picea sitchensis), western hemlock (Tsuga heterophylla), and Douglas fir (Pseudotsuga menziesii). Red alder (Alnus rubra) is present in disturbed and riparian areas and western redcedar (Thuja plicata) is found in swampy areas. In stabilized dune communities, shore pine (Pinus contorta) is the main successional species (Frenkel 1985) .

Vegetation on the dunal sheet is characterized by shore pine (Pinus contorta), rhododendron ( $R$. macrophyllum), salal (Gaultheria shallon), evergreen huckleberry (Vaccinium ovatum), showy scotch broom (Cyticus scoparius), blueberry, and other shrubs. European beach grass (Ammophila arenaria) has been planted on portions of the dunes in an attempt to stabilize them (Christensen 1982). In well-established dunal plant communities, the vegetation is represented by a mix of evergreen huckleberry, salal, shore pine, Douglas fir, sitka spruce, western hemlock, and western redcedar (McConnaughey 1980) .

\section{LIMNOLOGICAL BACKGROUND}

The literature indicates that each of the lakes has received periodic research attention since the first description of Woahink Lake by Evermann and Meek (1897). Studies conducted between 1938 and 1970 were primarily 
concerned with fisheries management but also included supporting limnological data. In contrast to current nationwide efforts to decrease nutrient inputs and reverse eutrophication, Griffiths and Yeoman (1938) suggested that some of the less productive coastal lakes, such as Woahink Lake, should be considered as candidates for nutrient enrichment to increase fish production. No deliberate enrichment activities have ever been undertaken on any of the three lakes and, since 1970, studies of the lakes have been primarily concerned with water quality or limnological research issues.

\section{Physical Description}

Generally, Mercer, Munsel, and Woahink Lakes can be described as warm monomictic lakes. This type of lake is common in temperate latitudes near the ocean and is characterized by water temperatures greater than $4^{\circ} \mathrm{C}$, free circulation of water during the winter, and summer stratification (Wetzel 1983).

The oregon Fish Commission studies in the early 1960's by Oakley (1962a, 1962b) and McGie and Breuser (1962) are the original sources of the morphometric data and bathymetric maps for Mercer, Munsel, and Woahink Lakes. Table I lists the physical characteristics for each of the lakes as presented in Johnson et al. (1985). Figures 3, 4, and 5 are bathymetric maps of Mercer Lake, Munsel Lake, and Woahink Lake, respectively. 
TABLE I

PHYSICAL CHARACTERISTICS FOR MERCER LAKE, MUNSEL LAKE, AND WOAHINK LAKE

\begin{tabular}{|c|c|c|c|}
\hline & Mercer L. & Munsel L. & Woahink L. \\
\hline Elevation & $9.8 \mathrm{~m}$ & $27.4 \mathrm{~m}$ & $11.6 \mathrm{~m}$ \\
\hline Area (hectares) & $145.3 \mathrm{ha}$ & $44.5 \mathrm{ha}$ & 331.9 ha \\
\hline Maximum Depth & $11.6 \mathrm{~m}$ & $21.6 \mathrm{~m}$ & $20.7 \mathrm{~m}$ \\
\hline Mean Depth & $7.1 \mathrm{~m}$ & $9.3 \mathrm{~m}$ & $9.9 \mathrm{~m}$ \\
\hline Mean/Maximum Depth & 0.61 & 0.43 & 0.48 \\
\hline Volume & $1.0 \times 10^{7} \mathrm{~m}^{3}$ & $4.2 \times 10^{6} \mathrm{~m}^{3}$ & $3.3 \times 10^{7} \mathrm{~m}^{3}$ \\
\hline Area $(<3.3 \mathrm{~m})$ & $13 \%$ & 248 & $17 \%$ \\
\hline Volume Development & 1.83 & 1.29 & 1.44 \\
\hline Shape Factor & 3.2 & 2.0 & 3.5 \\
\hline Shoreline Length & $13.8 \mathrm{~km}$ & $4.8 \mathrm{~km}$ & $22.9 \mathrm{~km}$ \\
\hline Watershed Area & $22.0 \mathrm{~km}^{2}$ & $4.4 \mathrm{~km}^{2}$ & $4.4 \mathrm{~km}^{2}$ \\
\hline Retention Time & $0.33 \mathrm{yr}$ & $1.0 \mathrm{yr}$ & $1.2 \mathrm{yr}$ \\
\hline
\end{tabular}

Summary of Earlier Limnological studies

Table II lists selected researchers and selected water quality variables investigated at the study lakes. Mercer Lake has been studied by Griffiths and Yeoman (1938), Saltzman (1961), Oakley (1962a), McGie (1964a), Skeesick (1969, 1970a), McHugh (1972 unpublished, 1979 unpublished), Kavanagh (1973), Larson (1974), Bryant (1979), Johnson et al. (1985), claska (1988), Sweet (1990a), Larson and Salinas (1991 unpublished), and Daggett and Petersen (1993, 1994). After the initial study by Griffiths and Yeoman (1938), Munsel Lake was studied by Oakley (1962b), Chapman and 


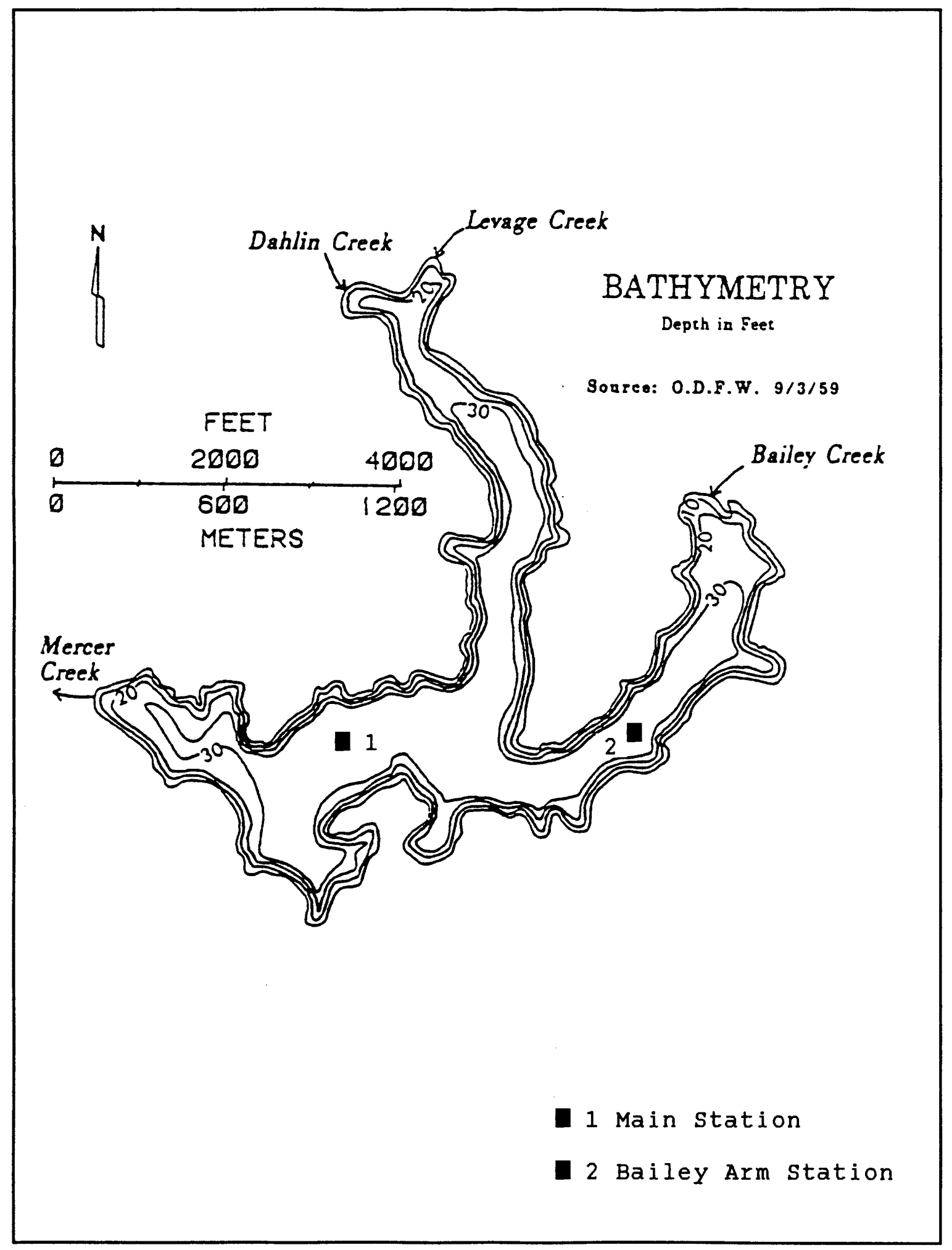

Fiqure 3. Bathymetric map of Mercer Lake showing location of sampling stations. (From Johnson et al. 1985.) 


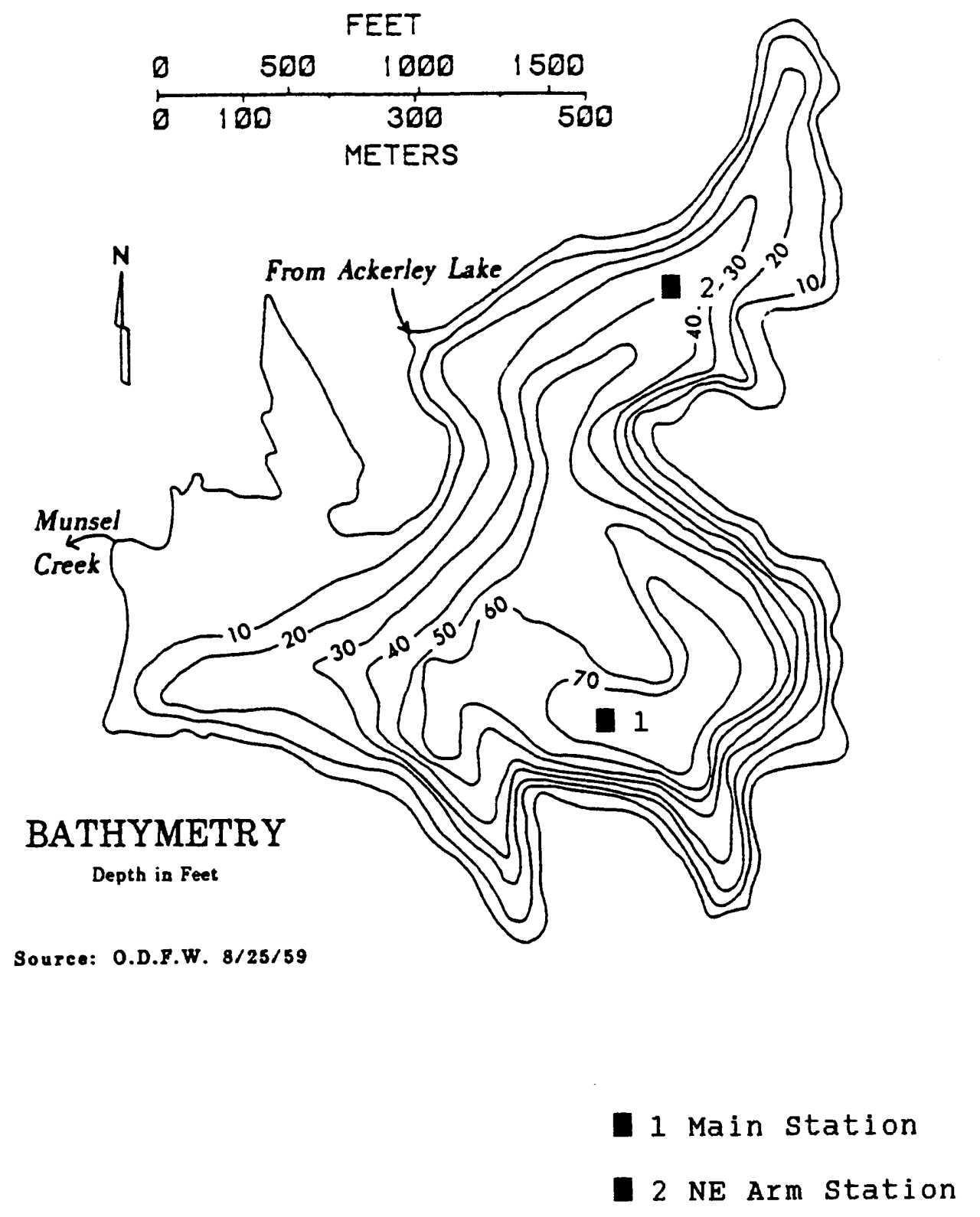

Fiqure 4. Bathymetric map of Munsel Lake showing location of sampling stations. (From Johnson et al. 1985.) 


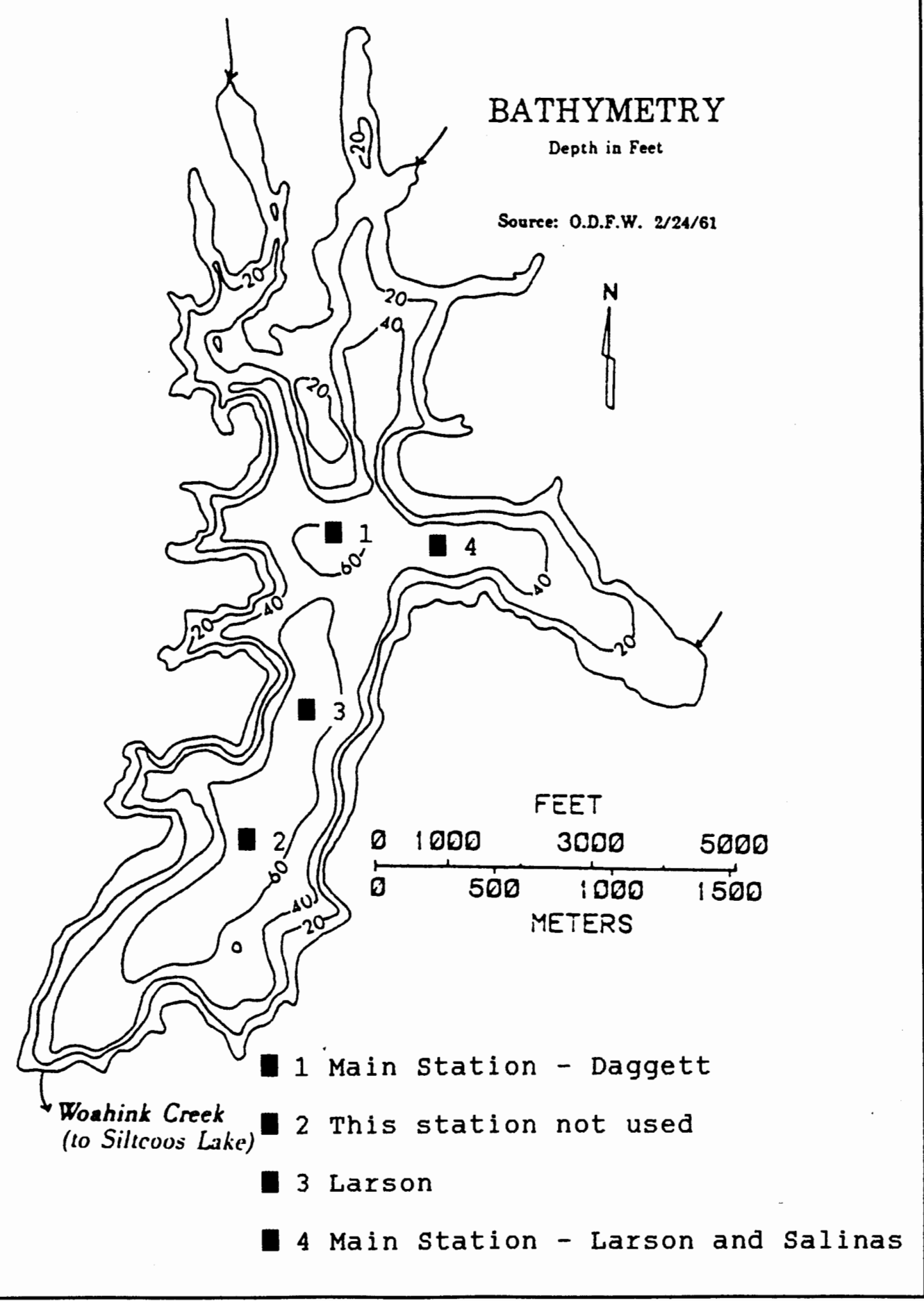

Fiqure 5. Bathymetric map of Woahink Lake showing location of sampling stations. (From Johnson et al. 1985.) 
TABLE II

\section{SELECTED RESEARCHERS AND SELECTED WATER QUALITY VARIABLES INVESTIGATED AT MERCER, MUNSEL, AND WOAHINK LAKES}

\begin{tabular}{|c|c|c|c|c|c|c|c|c|c|c|c|c|c|c|c|}
\hline Mercer Lake & Prod & Phyt & Chl a & Zoop & Bent & Temp & DO & Nutr & Alk & $\mathrm{pH}$ & Secc & Opt & Cond & lons & Red \\
\hline Grifitith and Yeoman (1938) & & & & & $x$ & $\mathrm{x}$ & $\mathrm{x}$ & & $\mathrm{X}$ & & & & & & \\
\hline Saltzman (1961) & & & & & $\bar{x}$ & $\bar{X}$ & $\bar{x}$ & & $\bar{X}$ & $\bar{x}$ & $\mathbf{x}$ & & & & \\
\hline Oakley (1962a) & & & & & $\bar{x}$ & $\bar{x}$ & $\bar{x}$ & & $\bar{x}$ & $\bar{x}$ & $\bar{x}$ & & & & \\
\hline McHugh (1972) & & $\bar{x}$ & & $\bar{x}$ & & & & & & & & & & & \\
\hline Kavanagh (1973) & $\bar{x}$ & & $\bar{x}$ & $\bar{x}$ & & $\bar{x}$ & $\bar{x}$ & $\mathbf{x}$ & & $\mathrm{X}$ & $\bar{x}$ & $\bar{x}$ & & & \\
\hline Larson (1974) & & & & & & $\bar{x}$ & $\bar{x}$ & $\bar{X}$ & $\bar{x}$ & $\bar{x}$ & $\bar{x}$ & & $\bar{X}$ & $\bar{X}$ & \\
\hline Bryant (1979) & & & $\bar{x}$ & & & $\bar{x}$ & $\bar{x}$ & $\bar{x}$ & $\bar{x}$ & $\bar{x}$ & $\bar{x}$ & & $\bar{x}$ & $\bar{x}$ & \\
\hline McHugh (1979) & & $\mathbf{x}$ & & $\bar{x}$ & & & & & & & & & & & \\
\hline Johnson et al (1985) & & $\bar{x}$ & $\bar{x}$ & & & $\bar{X}$ & $\overline{\mathbf{X}}$ & $\bar{x}$ & $\bar{x}$ & $\bar{x}$ & $\bar{x}$ & & $\bar{x}$ & $\bar{x}$ & \\
\hline Claska (1988) & & & & $\bar{x}$ & & & & & & & & & & & \\
\hline Swoet (1990a) & & $\bar{x}$ & $\bar{x}$ & & & $\bar{x}$ & $\bar{x}$ & $\bar{x}$ & $\bar{x}$ & $\bar{x}$ & $\bar{x}$ & & $\bar{x}$ & & \\
\hline Larson and Salinas (1991) & $\bar{x}$ & $\bar{x}$ & $\bar{x}$ & $\bar{x}$ & $\bar{x}$ & $x$ & $\bar{x}$ & & $\bar{x}$ & $x$ & $x$ & & $\bar{x}$ & & $\bar{x}$ \\
\hline Daggett and Petersen (1993) & & $\bar{x}$ & $\bar{x}$ & & & $\bar{x}$ & $\bar{X}$ & $\bar{X}$ & $\bar{x}$ & & $\bar{x}$ & $\mathbf{x}$ & $\bar{x}$ & & \\
\hline Daggett and Petersen (1994) & & & & & & & & & & & $\bar{x}$ & & & & \\
\hline Munsel Lake & Prod & Phyt & $\mathrm{Chl} \mathrm{a}$ & Zoop & Bent & Temp & DO & Nutr & Alk & $\mathrm{pH}$ & Socc & Opt & Cond & lons & Red \\
\hline Griffith and Yeoman (1938) & & & & & $\mathrm{x}$ & $\mathrm{x}$ & $\mathbf{X}$ & & $\mathbf{x}$ & & & & & & \\
\hline Oakley (1962b) & & & & & $\bar{x}$ & $\bar{X}$ & $\bar{x}$ & & $\bar{x}$ & $\bar{x}$ & $\mathbf{x}$ & & & & \\
\hline Chapman and Fortune (1963) & & & & $\bar{x}$ & & & & & & & & & & & \\
\hline Hansen (1963) & & & & & & & & $\bar{X}$ & & & & & & & \\
\hline Skeesick (1965) & & & & & & $\mathbf{x}$ & $\mathbf{x}$ & & & & & & & & \\
\hline Skeesick and Gaumer (1970) & & & & & & $\bar{x}$ & $\bar{x}$ & & $\bar{x}$ & & $\bar{x}$ & & & & \\
\hline Kavanagh (1973) & $\bar{x}$ & & $\bar{x}$ & $\bar{x}$ & & $\bar{x}$ & $\bar{x}$ & $\bar{x}$ & & $\bar{x}$ & $\bar{x}$ & $\bar{x}$ & & & \\
\hline McHugh (1973) & & $\bar{x}$ & & $\bar{x}$ & & & & & & & & & & & \\
\hline Larson (1974) & & & & & & $\bar{x}$ & $\bar{x}$ & $\bar{x}$ & $\bar{x}$ & $\bar{x}$ & $\bar{x}$ & & $\bar{x}$ & $\bar{x}$ & \\
\hline Bryant (1979) & & & $\bar{x}$ & & & $\bar{x}$ & $\bar{x}$ & $\bar{x}$ & $\bar{x}$ & $\bar{x}$ & $\bar{x}$ & & $\bar{x}$ & $\bar{X}$ & \\
\hline Johnson et al (1985) & & $\mathbf{X}$ & $\bar{x}$ & & & $\bar{x}$ & $\bar{X}$ & $\bar{x}$ & $\bar{x}$ & $\bar{x}$ & $\bar{x}$ & & $\bar{x}$ & $\bar{x}$ & \\
\hline Claska (1988) & & & & $\overline{\mathbf{X}}$ & & & & & & & & & & & \\
\hline Larson and Salinas (1991) & $\bar{x}$ & $\bar{x}$ & $\bar{x}$ & $\overline{\mathbf{X}}$ & $\bar{x}$ & $\bar{x}$ & $\bar{x}$ & & $\bar{x}$ & $\bar{x}$ & $\bar{x}$ & & $\bar{x}$ & & $\bar{x}$ \\
\hline Daggett and Petersen (1993) & & $\bar{x}$ & $\bar{x}$ & & & $\bar{x}$ & $\bar{x}$ & $\bar{x}$ & $\bar{x}$ & & $\bar{x}$ & $\mathbf{x}$ & $\bar{x}$ & & \\
\hline Daggett and Petersen (1994) & & & & & & & & & & & $\bar{x}$ & & & & \\
\hline Woahink Lake & Prod & Phyt & $\mathrm{Chla}$ & Zoop & Bent & Temp & DO & Nutr & Alk & $\mathrm{pH}$ & Sece & Opt & Cond & lons & Red \\
\hline Griffith and Yooman (1938) & & & & & $\bar{x}$ & $x$ & $\mathrm{x}$ & & $x$ & & & & & & \\
\hline Saltzman (1962) & & & & & $\bar{x}$ & $\bar{X}$ & $\bar{x}$ & & $\bar{x}$ & $\bar{x}$ & $\bar{x}$ & & & & \\
\hline McGie and Breuser (1962) & & & & & $\bar{x}$ & $\bar{x}$ & $\bar{x}$ & & $\bar{x}$ & $\bar{x}$ & $\bar{x}$ & & & & \\
\hline Chapman and Fortune (1963) & & & & $\overline{\mathbf{X}}$ & & & & & & & & & & & \\
\hline Larson (1970a) & $\overline{\mathbf{X}}$ & $\bar{X}$ & $\bar{x}$ & & & $\bar{X}$ & & & $\bar{X}$ & & $\bar{x}$ & $\bar{X}$ & $\bar{x}$ & & \\
\hline Malick (1970) & & & & $\bar{x}$ & & $\bar{X}$ & & & & & & & & & \\
\hline Maloney et al (1972) & & & & & & & & $\bar{x}$ & & $\bar{x}$ & & & & & \\
\hline McHugh (no date) & & $\bar{x}$ & & $\bar{x}$ & & & & & & & & & & & \\
\hline Larson (1974) & & & & & & $\bar{x}$ & $\bar{x}$ & $\bar{x}$ & $\bar{x}$ & $\bar{x}$ & $\bar{x}$ & & $\bar{x}$ & $\bar{x}$ & \\
\hline Bryant (1979) & & & $\bar{x}$ & & & $\bar{x}$ & $\bar{X}$ & $\bar{x}$ & $\bar{x}$ & $\bar{X}$ & $\bar{x}$ & & $\bar{x}$ & $\bar{x}$ & \\
\hline Johnson et al (1985) & & $\mathbf{x}$ & $x$ & & & $\bar{x}$ & $\bar{x}$ & $x$ & $\bar{x}$ & $\bar{x}$ & $\bar{x}$ & & $\bar{x}$ & $\mathbf{x}$ & \\
\hline Claska (1988) & & & & $\bar{x}$ & & & & & & & & & & & \\
\hline Swoet $(1990 b)$ & & $\bar{x}$ & $\bar{x}$ & & & $\bar{x}$ & $\bar{x}$ & $\bar{x}$ & $\bar{x}$ & $\overline{\mathbf{X}}$ & $\bar{x}$ & & $\bar{x}$ & $\bar{x}$ & \\
\hline Larson and Salinas (1991) & $\bar{x}$ & $\bar{x}$ & & $\bar{x}$ & $\overline{\mathbf{X}}$ & $\bar{x}$ & $\bar{x}$ & & $\bar{x}$ & $\bar{x}$ & $\bar{x}$ & & $\bar{x}$ & & $\bar{x}$ \\
\hline Daggett and Petersen (1993) & & $\bar{x}$ & $\bar{x}$ & & & $\bar{x}$ & $\bar{x}$ & $\bar{x}$ & $\bar{x}$ & & $\mathbf{X}$ & $\bar{x}$ & $\bar{x}$ & & \\
\hline Daggett and Petersen (1994) & & & & & & $\bar{x}$ & $\bar{X}$ & & & & $\bar{x}$ & & & & \\
\hline
\end{tabular}

Note: Prod=primary productivity, Phyt=phytoplankton, Ch a=chlorophyll a, Zoop=zooplankton, Bent=benthic invertebrates,

Temp=temperature, DO=dissolved oxygen, Nutr=nutrients, Alk=alkalinity, $\mathrm{pH}=\mathrm{pH}$, Secc=Secchi Depth,

Opt=optical characteristics, Cond=conductivity, lons=ion chemistry, Red=reduction/oxidation potential

Fortune (1963), Hansen (1963), Skeesick (1965, 1970b),

Skeesick and Gaumer (1969, 1970), McHugh (1972 unpublished, 1979 unpublished), Kavanagh (1973), Larson (1974), Bryant 
(1979), Johnson et al. (1985), Claska (1988), Larson and Salinas (1991 unpublished), and Daggett and Petersen (1993, 1994)

Data from Woahink Lake have been reported by Evermann and Meek (1897), Griffiths and Yeoman (1938), Phinney and McLachlan (1956), McGie and Breuser (1962), Saltzman (1962), Chapman and Fortune (1963), McGie (1964a, 1964b), Gahler (1969), Larson (1970a,b), Malick (1971), Maloney et al. (1972), Larson (1974), Miller et al. (1974), Bryant (1979), McHugh (no date unpublished), Johnson et al. (1985), Sweet (1990b), Larson and Salinas (1991 unpublished), and Daggett and Petersen (1993, 1994).

Griffiths and Yeoman (1938) gathered fisheries productivity data when these lakes were first studied. oxygen deficits were reported in the hypolimnion of each lake during summer stratification, indicating consumption of organic materials by bacteria. Based on the weight of benthic organisms per unit area, they ranked the productivity of their ten study lakes. Mercer Lake was ranked first, Munsel Lake second, and Woahink Lake tenth. Oakley $(1962 \mathrm{a}, \mathrm{b})$ and McGie and Breuser (1962) ranked the potential fisheries productivity of Mercer, Munsel, and Woahink Lakes, respectively, based on biological and chemical evidence collected during a coastal lakes study. Potential productivity was higher than average at Mercer Lake, low at Munsel Lake, and lower than average at Woahink 
Lake.

Larson (1970a, 1970b, 1972) characterized Woahink Lake as oligotrophic based on primary productivity measurements, chlorophyll a concentrations, water transparency, concentrations of dissolved minerals, basin morphometry, and climate. Larson suggested that the summer hypolimnetic oxygen deficit was a result of redox reactions occurring at the water-sediment interface. The oligotrophic characterization was reconciled with the characterization of the lake as mesotrophic based on Rodhe's (1969) trophic scale.

Kavanagh described Mercer and Munsel Lakes as eutrophic tending toward mesotrophic according to Rodhe's (1969) trophic scale based on primary production. Kavanagh stated that these trophic characterizations were supported by morphometric features, measurements of chlorophyll a , water transparency, and water chemistry.

Johnson et al. (1985) described the trophic status of 202 Oregon lakes based primarily on the application of Carlson's (1977) trophic state index to data for total phosphorus, chlorophyll a, and Secchi Disk transparency. The lakes were described as follows: Mercer Lake, mesotrophic but nearly eutrophic; Munsel Lake, mesotrophic tending toward oligotrophic; and Woahink Lake, oligotrophic. Sweet $(1990 a, b)$ described the trophic status of Mercer Lake and Woahink Lake based on the application of Carlson's 
(1977) trophic state index to total phosphorus, chlorophyll a, and transparency data. Additionally, sweet estimated trophic status based on biovolume (Sweet 1986). Mercer Lake was described as eutrophic and Woahink was described as oligotrophic tending toward mesotrophic. 


\section{MATERIALS AND METHODS}

Materials and methods are summarized below for data collected by Larson and Salinas (1991 unpublished) and Daggett and Petersen (1993). Appendix A contains the details of the materials and methods for the phytoplankton primary productivity measurements, chlorophyll a analysis, phytoplankton identification and enumeration, and zooplankton identification and enumeration.

\section{LARSON AND SALINAS METHODS}

The phytoplankton primary productivity was measured in situ using ${ }^{14} \mathrm{C}$. Water samples for identification and enumeration of phytoplankton and for analysis of chlorophyll a concentration were collected at various depths with a Van Dorn bottle. Phytoplankton samples were stored in $250 \mathrm{~mL}$ Nalgene bottles and preserved with Lugol's solution (1\% of sample volume). Phytoplankton samples collected by Larson and Salinas (1991 unpublished) and by Daggett and Petersen (1993) were analyzed by Jim Sweet of Aquatic Analysts, Inc.

John Salinas carried out all collection and analysis of water samples for chlorophyll a. Water samples were stored in $250 \mathrm{~mL}$ amber HDPE bottles which were placed on ice immediately after being filled. An appropriate volume of 
sample, less than $50 \mathrm{~mL}$, was filtered within twenty-four hours through a .45 $\mu \mathrm{m}$ pore size Kimax membrane filter. The filters were wrapped in foil and placed on ice until they could be frozen in the laboratory. Filtered samples were stored frozen for up to one month before analysis. The filters were ground with aqueous acetone and analyzed fluorometrically using a Turner systems fluorometer (model 10-R). Chlorophyll a values were not corrected for pheophytin a.

Benthic samples were collected with a 6-inch-square Eckman dredge and sieved through a screened box. Collected material, including benthic organisms, were washed into a plastic bottle and preserved with $5 \%$ formalin. The samples were analyzed by Dr. Judith $\mathrm{Li}$ at Oregon State University. Samples were processed by subsampling to the smallest degree possible; that is, Dr. Li tried to count as much of the original sample as possible. Benthic invertebrates were sorted, identified to species, and enumerated.

Samples for identification and enumeration of zooplankton were collected from vertical tows with a zooplankton net. The net had a pore-mesh size of $64 \mu \mathrm{m}$ and a 12-inch mouth. The net efficiency was approximately $90 \%$. Samples were stored in $500 \mathrm{~mL}$ Nalgene bottles and preserved with 5\% formalin. Identification and enumeration of the samples was performed by Allan Vogel of $\mathrm{ZP}^{\prime} \mathrm{s}$ Taxonomic Service. 
Temperature, dissolved oxygen, $\mathrm{pH}$, conductivity, turbidity, and oxidation-reduction potential were measured in situ from lake surface to bottom with a multiple-probe instrument (Hydrolab model 8000 ). The reported conductivity values are not corrected to standard temperature $\left(25^{\circ} \mathrm{C}\right)$.

Water samples were collected at various depths with a Van Dorn bottle and analyzed for turbidity, dissolved oxygen, $\mathrm{pH}$, and alkalinity. Turbidity was measured nephelometrically with a Hach 2100-A turbidimeter, dissolved oxygen was measured by the Winkler method, alkalinity was determined by potentiometric titration with $.05 \mathrm{M} \mathrm{H}_{2} \mathrm{SO}_{4}$, and $\mathrm{pH}$ was measured with a Hachone $\mathrm{pH}$ meter utilizing an electrode with a free-flow junction.

Lakewater transparency was measured routinely with a 20 cm diameter Secchi Disk.

\section{DAGGETT AND PETERSEN METHODS}

Dissolved oxygen and temperature profiles were measured at one meter intervals in the water column with a YSI (Yellow Springs Instrument Co.) dissolved oxygen and temperature meter (model 158). In the field, the meter was calibrated against atmospheric oxygen with a correction for atmospheric pressure as indicated by the manufacturer's instructions. Dissolved oxygen measurements were also obtained at selected depths using the winkler Method with PAO as the titrant. All water samples were obtained using a 
Van Dorn type bottle (Scott Instruments, Seattle, Wa.).

Subsurface light attenuation was measured at one meter intervals with two different light meters. During June 1992, a Montedoro-Whitney underwater photometer (model LMA8A) was used to measure light as a percentage of surface light intensity. The meter was inadvertently calibrated above the water surface so the values recorded at $0 \mathrm{~m}$, just under the surface, are not $100 \%$ as they should be. The light values are accurate relative to each other and can be used to calculate a light extinction coefficient. During July 1992, a spherical Licor light sensor (model LI 185-B) connected to a Licor-1000 Data Logger was used to measure photosynthetically active radiation (PAR) as $\mu$ Einsteins $\mathrm{m}^{-2} \mathrm{~s}^{-1}$. Water transparency was measured with a $20 \mathrm{~cm}$ diameter secchi Disk.

Conductivity was measured with a YSI meter (model 33 SCT) and reported in units of $\mu$ mhos $\mathrm{cm}^{-1}$. Data were corrected to standard temperature $\left(25^{\circ} \mathrm{C}\right)$.

Water samples for chlorophyll a analysis were collected at $.5 \mathrm{~m}$, in the metalimnion, and in the upper hypolimnion. Specific sampling depths were selected based on the temperature profile. During June 1992, triplicate samples were taken at each depth and stored using three different methods in an effort to determine the most effective method for chlorophyll sample preservation. During July 1992, all filtered samples were stored in screw-top test tubes 
containing aqueous acetone. In the laboratory, chlorophyll a concentrations were determined fluorometrically and corrected for the presence of pheophytin $\underline{a}$, the primary degradation product of chlorophyll a.

Water samples for the analysis of total phosphorus, $P_{T}$, were collected at $0.5 \mathrm{~m}$. The samples were transferred to $500 \mathrm{~mL}$ acid-washed plastic bottles provided by the DEQ Laboratory. Each sample was acidified with 12 drops of concentrated $\mathrm{H}_{2} \mathrm{SO}_{4}$ and stored on ice for a maximum of five days. The samples were analyzed by the DEQ Laboratory using Standard Method 4500-PE (APHA 1992).

Samples for phytoplankton analysis were collected at .5 $m$ and from the upper hypolimnion. The samples were stored in $250 \mathrm{~mL}$ plastic bottles and preserved with $2.5 \mathrm{~mL}$ of Lugol's solution.

Supplementary limnological data were collected by volunteers with the Oregon Citizen Lake Watch program. These data included secchi depth $(20 \mathrm{~cm}$ diameter disk) and dissolved oxygen (measured at Woahink Lake only, using a LaMotte Co. dissolved oxygen test kit no. 7414). Water samples for dissolved oxygen analyses were collected with a Van Dorn type bottle. 


\section{RESULTS}

\section{TEMPERATURE AND DISSOLVED OXYGEN}

Second to water, oxygen is the most basic facet of lake biology; all aerobic organisms require oxygen and changes in nutrient availability are controlled by seasonal changes from aerobic to anaerobic environments (Wetzel 1983). The rate and total amount of hypolimnetic oxygen reduction is relative to the amount of organic material present in the lake.

Dissolved oxygen and temperature profiles were measured in each of the lakes by Griffiths and Yeoman (1938) and have been measured by most subsequent researchers. As mentioned previously, all of the lakes can be described as warm monomictic types. This lake type is common in temperate latitudes near the ocean and is characterized by water temperatures greater than $4^{\circ} \mathrm{C}$, free circulation during the winter, and summer stratification (Wetzel 1983). In the subsequent discussion, the thermocline is defined as the plane of maximum decrease of temperature with respect to depth (Wetzel 1983).

The study lakes were thermally stratified in early June and remained so until late september. Occasionally, the period of stratification extended from early May through 
mid-November (Kavanagh 1973). Griffith and Yeoman's (1938) data showed that each lake developed a clinograde oxygen curve. In 1938, anoxia developed in the hypolimnion of Mercer and Munsel Lakes and near anoxia occurred in Woahink Lake.

In Mercer Lake, the thermocline typically deepened from $6 \mathrm{~m}$ to $8 \mathrm{~m}$ over the course of the summer. Based on an estimated depth-volume curve the hypolimnion volume decreased from approximately $50 \%$ to $25 \%$ of the total lake volume as the thermocline deepened seasonally. On the three sampling dates in 1991 and 1992, the entire hypolimnion was anoxic (Larson and Salinas 1991 unpublished, Daggett and Petersen 1993). Figure 6 compares the september 1991 dissolved oxygen and temperature profiles with an October 1938 dissolved oxygen profile.

In 1991 and 1992, water samples drawn from Mercer Lake's hypolimnion smelled strongly of hydrogen sulfide (Larson and Salinas 1991 unpublished, Daggett 1992 unpublished) . Under anaerobic conditions, bacterial decomposition of organic material may mediate the reduction of sulfate $\left(\mathrm{SO}_{4}{ }^{2-}\right)$ to sulfide $\left(\mathrm{H}_{2} \mathrm{~S}\right.$ and $\left.\mathrm{HS}^{-}\right)$. The reduction of sulfate to sulfide occurs as the redox potential falls below $100 \mathrm{mv}$ (Wetzel 1983). The hypolimnetic redox potential (not corrected for $\mathrm{pH}$ ) ranged from $100 \mathrm{mv}$ to $-250 \mathrm{mv}$ (Larson and Salinas 1991 unpublished). The reduction of sulfate and the oxidation of hydrogen sulfide play a significant role in the 


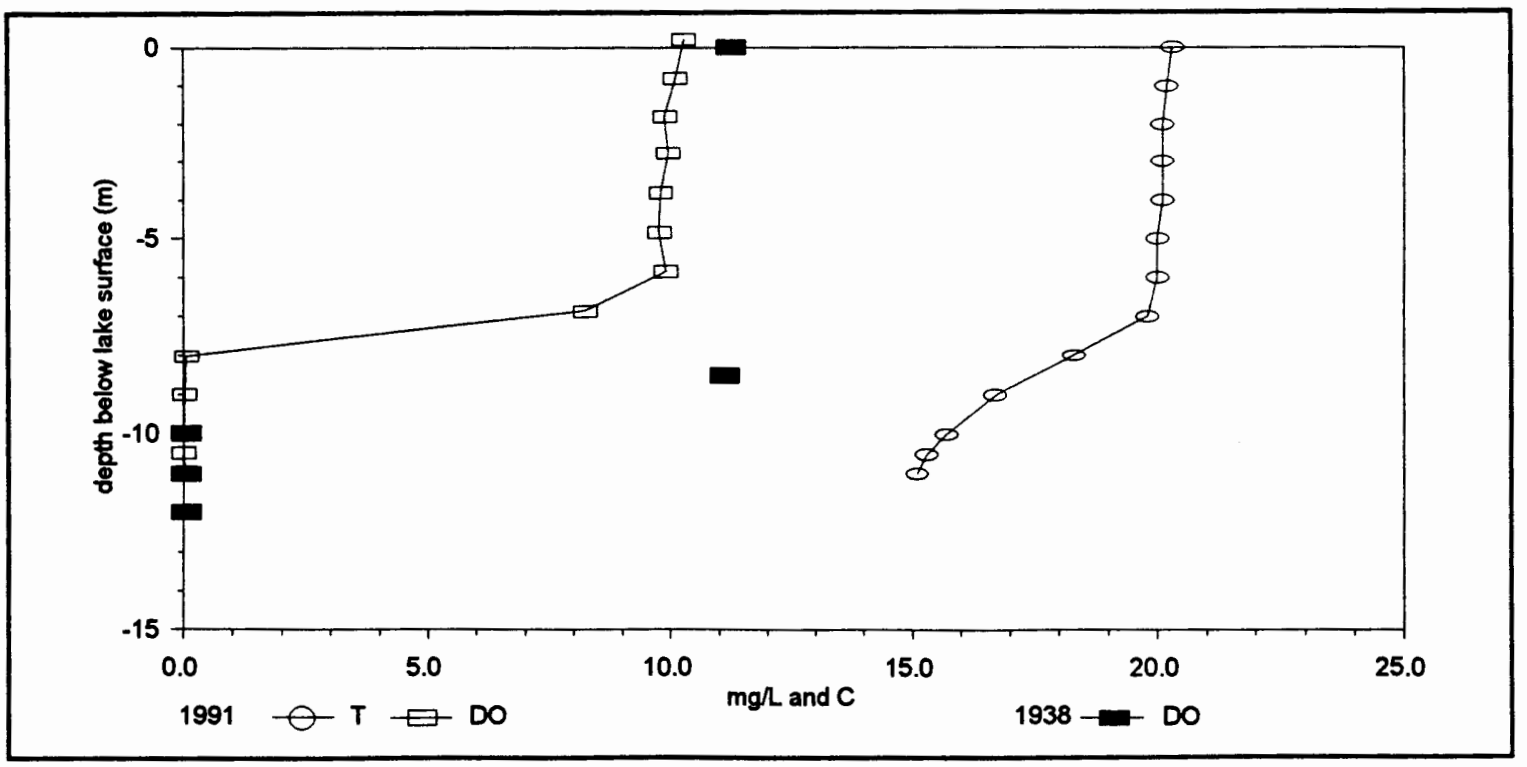

Fiqure 6. Dissolved oxygen and temperature profiles compared for Mercer Lake: October 11, 1938 and September 13, 1991.

mobilization of phosphorus and other nutrients (Wetzel 1983).

In Munsel Lake, the thermocline typically developed at $6 \mathrm{~m}$ and deepened to $10 \mathrm{~m}$ over the course of the summer. Hypolimnetic temperatures were maintained at $7-9{ }^{\circ} \mathrm{C}$. Of the three lakes, Munsel typically developed the steepest thermocline, maintained the most stable stratification, and possessed the thickest hypolimnion. Based on a depth-volume curve produced by Skeesick and Gaumer (1970) the hypolimnion represented approximately $65 \%$ of the lake volume.

of the study lakes, Munsel Lake possessed the most unusual oxygen profile. There was a pronounced metalimnetic oxygen maximum that appeared in a number of data sets and resulted in a positive heterograde dissolved oxygen curve. 
Figure 7 compares the June 1992 dissolved oxygen and temperature profiles with an october 1938 dissolved oxygen profile. This maximum was likely the result of oxygen produced by algal populations that developed in the metalimnion. Based on the two sampling dates in 1992, it appeared that by late July dissolved oxygen was nearly consumed below $15 \mathrm{~m}$.

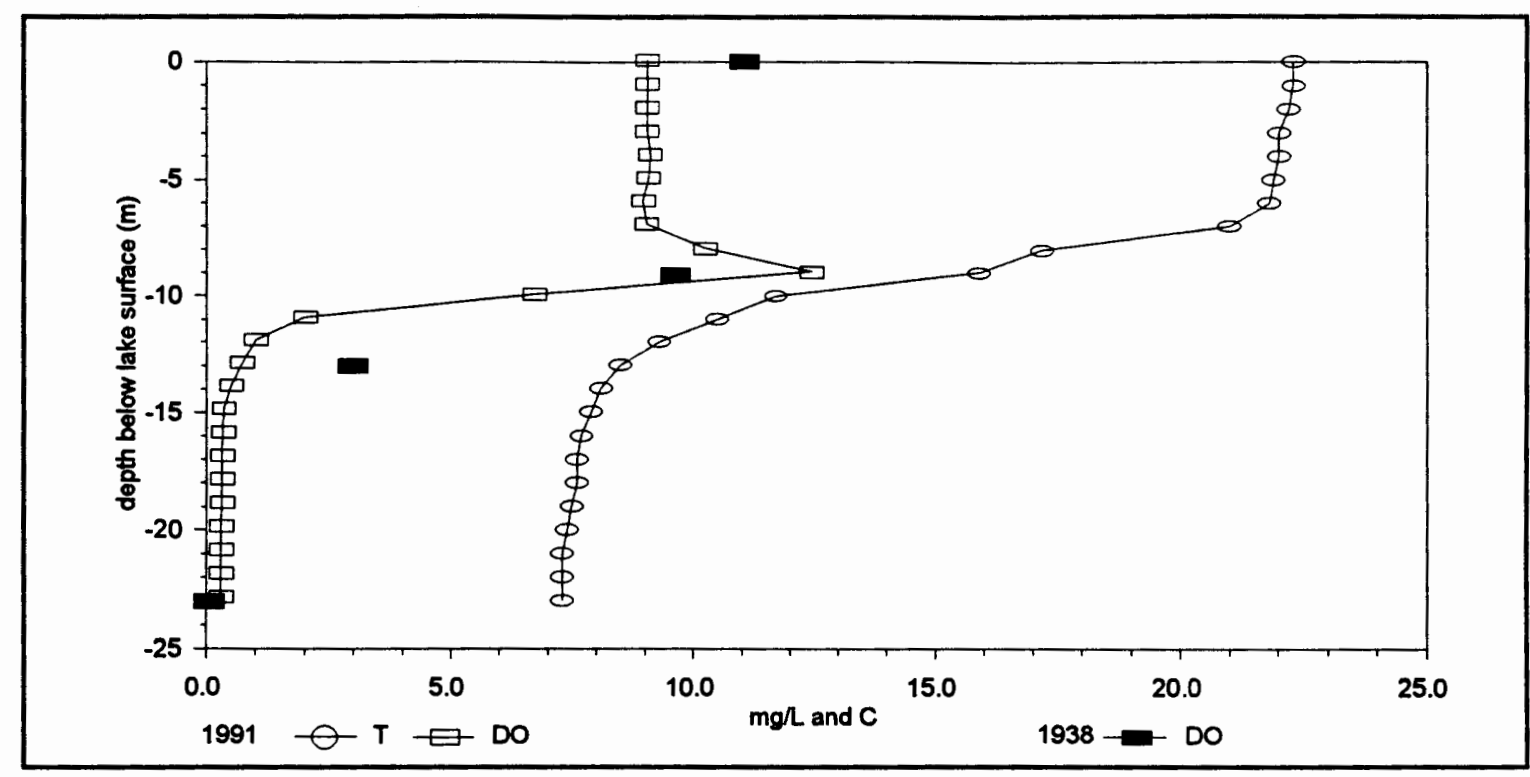

Figure 7. Dissolved oxygen and temperature profiles compared for Munsel Lake: October 20, 1938 and July 28, 1992.

In Woahink Lake, the thermocline typically deepened from $8 \mathrm{~m}$ to $16 \mathrm{~m}$ over the course of the summer. Based on an estimated depth-volume curve the hypolimnion volume decreased from approximately $35 \%$ to $10 \%$ of the total lake volume as the thermocline deepened seasonally. On the three sampling dates in 1991 and 1992, the entire hypolimnion contained reduced levels of dissolved oxygen. Figure 8 
compares the september 1991 dissolved oxygen and temperature profiles with a september 1938 dissolved oxygen profile. It appears that anoxic or near anoxic conditions occurred only near the sediment-water interface in the very deepest portion of the lake.

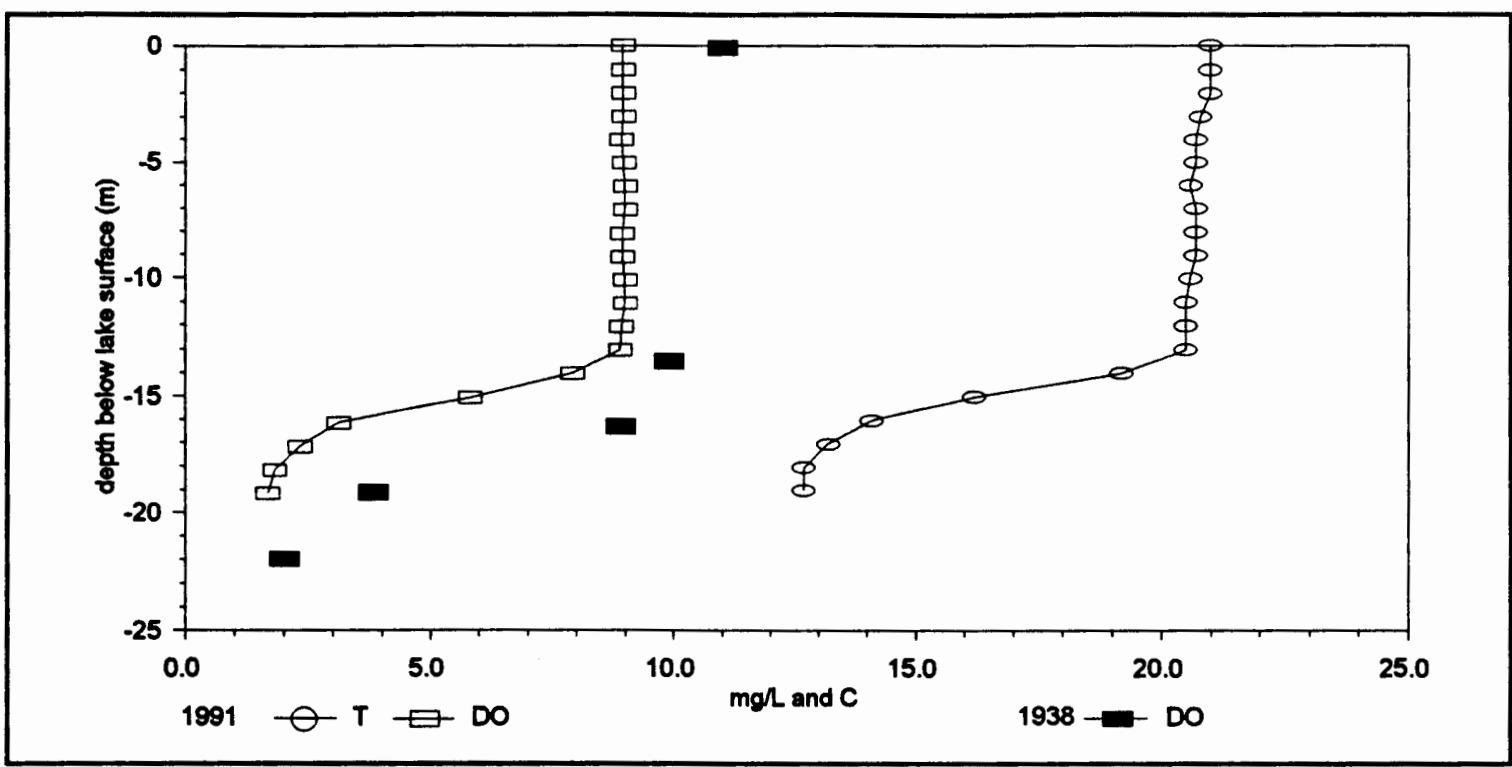

Figure 8. Dissolved oxygen and temperature profiles compared for Woahink Lake: September 3, 1938 and September 13, 1991.

\section{OPTICAL CHARACTERISTICS}

Secchi Disk depth has been measured since the early 1960's at each of the lakes (see Table II). These measurements represent the largest set of data for each lake. These data are summarized in Figures 9,10 , and 11 for Mercer, Munsel, and Woahink Lakes, respectively. The Secchi depth data are compiled in Appendix B. Since 1989, most secchi depth measurements have been made by volunteers of the Oregon Citizen Lake Watch Program (Daggett and 
Petersen 1993, 1994). At each of the lakes, the mean for all Secchi Disk depths is heavily influenced by the large number of measurements made by volunteers between 1989 and 1993.

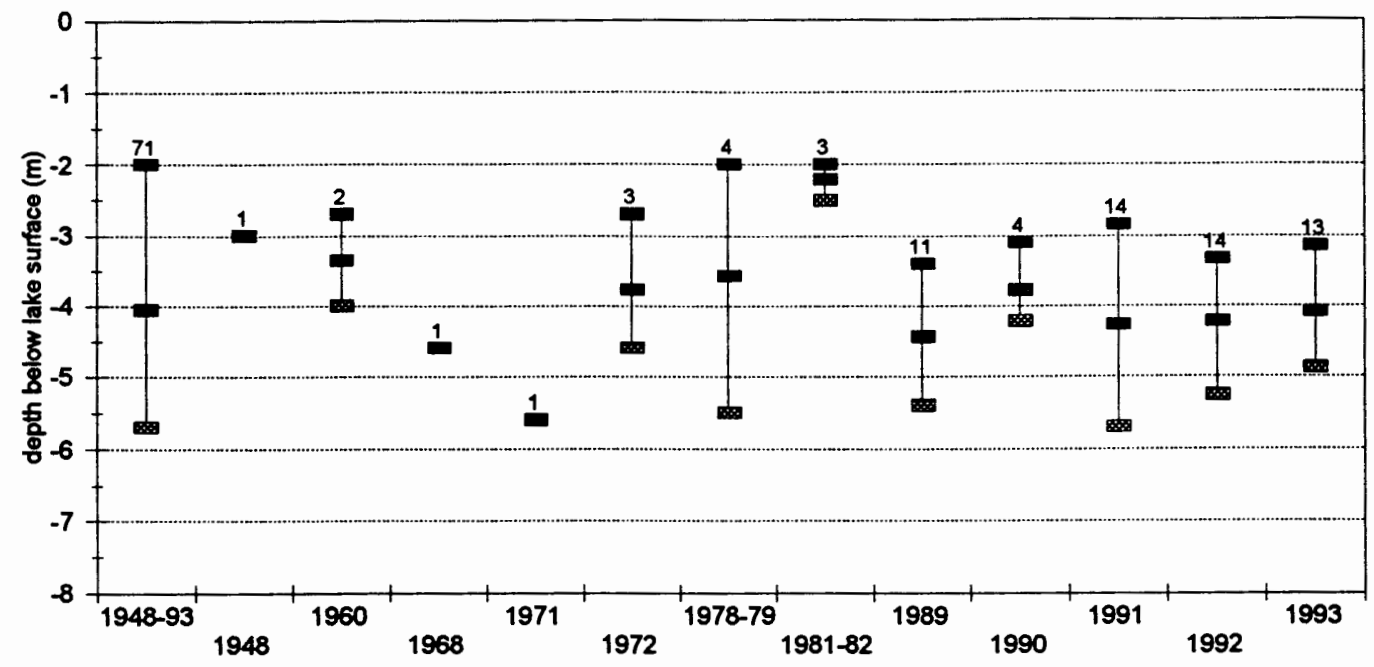

Figure 9. Secchi Disk depths measured in Mercer Lake 1948-1993: maximum, minimum, and mean. Number of measurements above bar.

At Mercer Lake, Secchi Disk depths ranged between $2.0 \mathrm{~m}$ and $5.7 \mathrm{~m}$ with a mean of $4.1 \mathrm{~m}$. By year, the mean Secchi depth has generally fallen within a $1 \mathrm{~m}$ range. From 1991 to 1993, the maximum secchi depth has decreased by $1 \mathrm{~m}$.

At Munsel Lake, Secchi depths have ranged from $3.6 \mathrm{~m}$ to $9.7 \mathrm{~m}$ with a mean of $5.7 \mathrm{~m}$. The deepest Secchi depths were recorded in 1979, 1992, and 1993. The shallowest secchi depth was recorded in May 1968.

At Woahink Lake, Secchi Disk depths ranged from $3.6 \mathrm{~m}$ to $9.7 \mathrm{~m}$ with a mean of $5.7 \mathrm{~m}$. Since 1990, Secchi Disk 


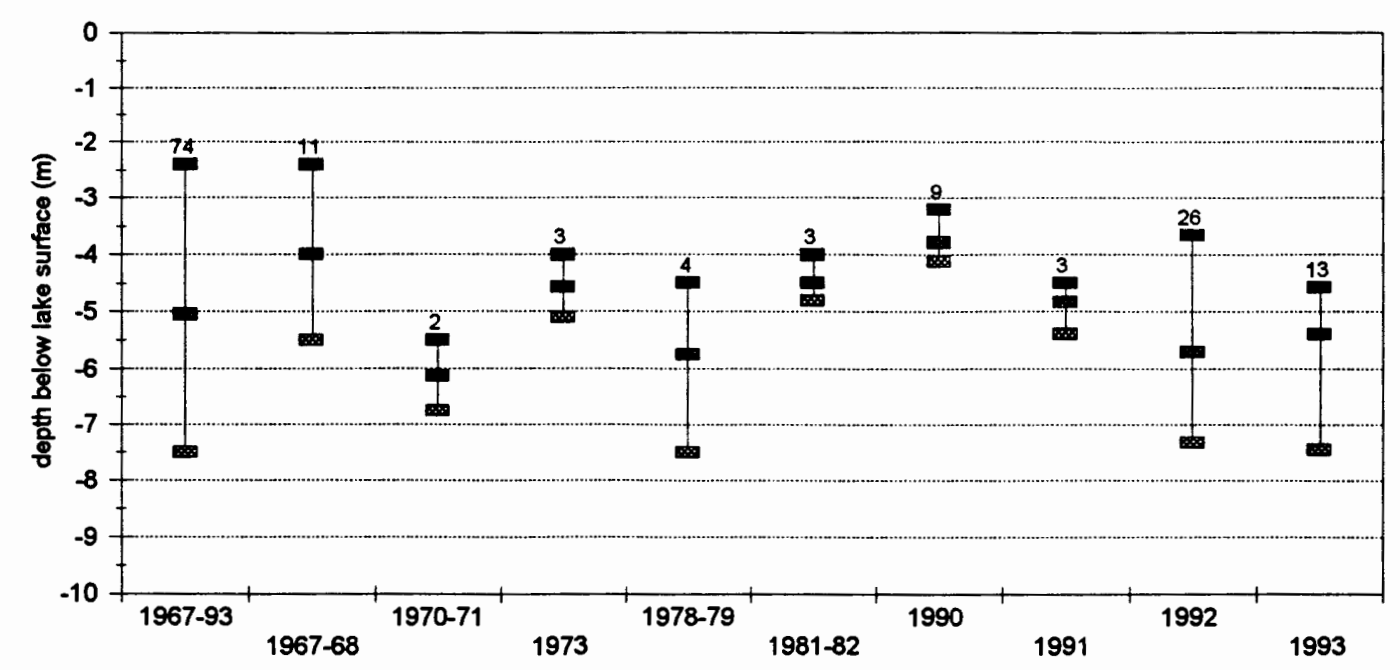

Figure 10. Secchi Disk depths measured in Munsel Lake 1967-1993: maximum, minimum, and mean. Number of measurements above bar.

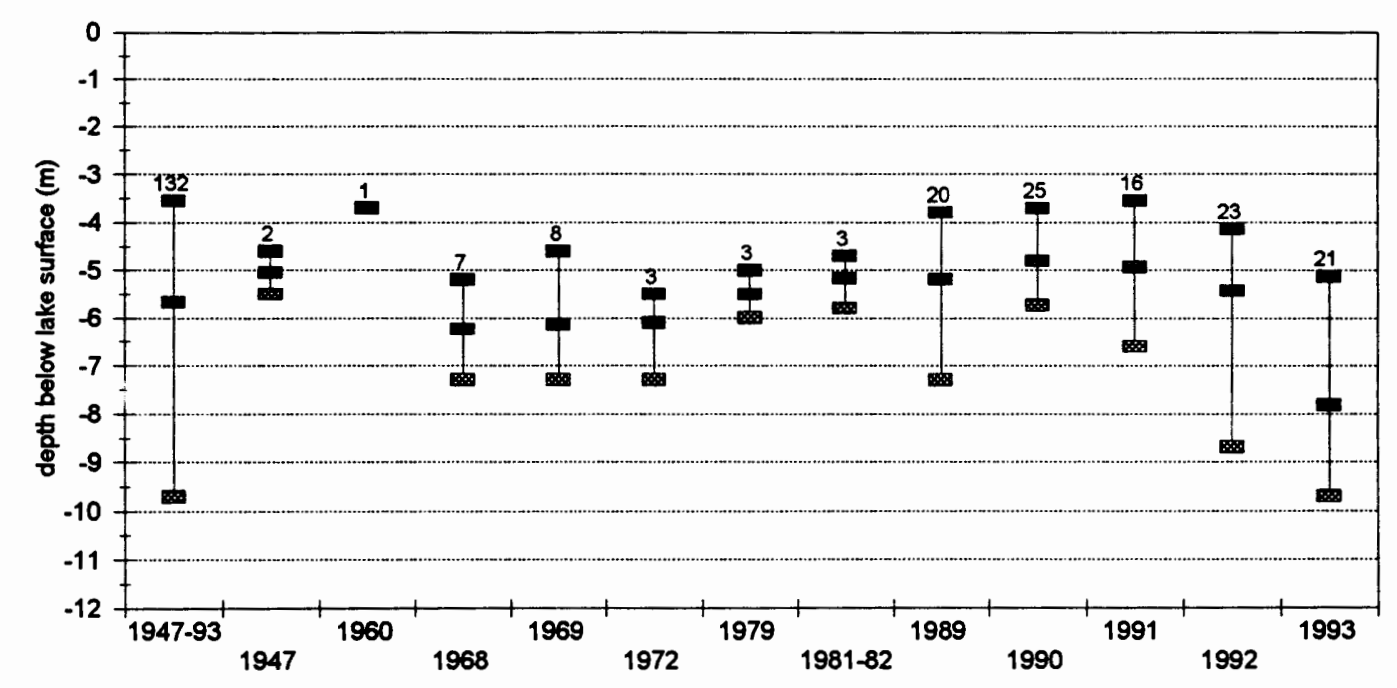

Fiqure 11. Secchi Disk depths measured in Woahink Lake 1947-1993: maximum, minimum, and mean. Number of measurements above bar.

transparency has steadily increased. The deepest secchi depth, $9.7 \mathrm{~m}$, was recorded in June 1993. The 1993 mean Secchi depth was at least $2.5 \mathrm{~m}$ greater than the mean for 
each of the previous four years.

Light transmission through the water column was measured at each of the lakes in 1969-1970 and in 1992 . These data are summarized in Table II and the complete data are listed in Appendix A. Extinction coefficients were always smallest in Woahink Lake and largest in Mercer Lake.

TABLE III

OPTICAL CHARACTERISTICS COMPARED BETWEEN STUDY LAKES

\begin{tabular}{||c|c|c|c|c|}
\hline Lake & Date & $\begin{array}{c}18 \text { Light } \\
\text { depth (m) }\end{array}$ & $\begin{array}{c}\text { Secchi } \\
\text { depth (m) }\end{array}$ & $\begin{array}{c}\text { Extinction } \\
\text { coefficient } \\
\left(\mathrm{m}^{-1}\right)\end{array}$ \\
\hline Mercer & $7-$ Sep-71 & 8.5 & 5.6 & .54 \\
\hline & $24-J u n-92$ & 7.5 & 4.1 & .64 \\
\hline & $29-J u l-92$ & 7.5 & 4.9 & $.50^{(1)}$ \\
\hline Munsel & 6-Sep-71 & 12 & 6.8 & .39 \\
\hline & $23-J u n-92$ & 10.5 & 6.3 & .46 \\
\hline Woahink & $28-J u l-92$ & $14^{(2)}$ & 5.1 & .33 \\
\hline & $24-J u 1-69$ & 14 & 6.6 & .28 \\
\hline & $29-J u 1-92$ & $16.5^{(2)}$ & 5.8 & .27 \\
\hline
\end{tabular}

Note:(1) Extinction changed with depth (see text).

(2) Value extrapolated from measured data.

At Mercer Lake on July 29, 1992, the extinction coefficient in the hypolimnion doubled from $.50 \mathrm{~m}^{-1}(0-6 \mathrm{~m})$ to $1.09 \mathrm{~m}^{-1}$ $(6-9 \mathrm{~m})$.

Wetzel's (1983) equation for estimating the extinction coefficient $(\epsilon)$ from the Secchi depth (SD), $\epsilon=1.7 / \mathrm{SD}$, underestimated the extinction coefficient in seven of the 
nine cases. Based on these nine cases, more accurate values for the numerator would be 2.7 for Mercer Lake, 2.4 for Munsel Lake, and 1.8 for Woahink Lake.

\section{NUTRIENTS}

Various nitrogen and phosphorus data have been collected for the study lakes since the early 1970's (see Table II). The majority of the nutrient data for the study lakes are summarized in Table IV and compiled in Appendix $c$. Missing from the table and the Appendix are Kavanagh's (1973) nitrogen data which were presented in the form of an isopleth graph. It was not possible to transform this graph into sampling depths and corresponding nitrogen concentrations.

Following Wetzel and Likens (1991), the following nomenclature and abbreviations are used to describe the concentrations of nutrients in their various forms: total phosphorus, $\left[\mathrm{P}_{\mathrm{T}}\right]$; soluble reactive phosphate-phosphorus or SRP, $\left[\mathrm{PO}_{4}-\mathrm{P}\right]$; total nitrogen (usually total Kjeldahl nitrogen or $\mathrm{TKN}),\left[\mathrm{N}_{\mathrm{T}}\right]$; ammonium nitrogen, $\left[\mathrm{NH}_{4}-\mathrm{N}\right]$; and nitrate nitrogen, $\left[\mathrm{NO}_{3}-\mathrm{N}\right]$.

At each of the lakes, different types of nutrient samples have been collected sporadically. This patchwork of values makes it difficult to make many comparisons over time. Also, Johnson et al. (1985) warn readers to use the 
TABLE IV

SUMMARY OF NITROGEN AND PHOSPHORUS DATA FOR THE STUDY LAKES (units of $\mathrm{mg} / \mathrm{L}$ )

\begin{tabular}{||l|l|c|c|c|c|c||}
\hline \multicolumn{2}{|c|}{} & $\mathrm{NH}_{4}-\mathrm{N}$ & $\mathrm{NO}_{3}-\mathrm{N}$ & $\mathrm{N}_{\mathrm{T}}$ & $\mathrm{P}_{\mathrm{T}}$ & $\mathrm{PO}_{4}-\mathrm{P}$ \\
\hline & Count & 5 & 12 & 2 & 20 & 5 \\
\hline & Min & $<.01$ & $<.03$ & .29 & .004 & $<.003$ \\
\hline & Max & .19 & 1.40 & .40 & .355 & .02 \\
\hline Munsel & Mean & .07 & .44 & .35 & .06 & .02 \\
\hline & Min & $<.01$ & $<.01$ & $<.1$ & $<.01$ & $<.001$ \\
\hline & Max & .15 & .22 & .3 & .2 & .16 \\
\hline & Mean & .07 & .07 & .25 & .06 & .05 \\
\hline Woahink & Count & 6 & 12 & 3 & 8 & 12 \\
\hline & Min & $<.01$ & .02 & .2 & .002 & .001 \\
\hline & Max & .14 & .21 & .43 & .037 & .10 \\
\hline & Mean & .06 & .08 & .34 & .01 & .03 \\
\hline
\end{tabular}

nutrient data with caution because of excessive holding times for samples. Larson (personal communication) also made this warning in regard to data reported by Bryant (1979) and Larson (1974). Data collected by Larson (1974) and Bryant (1979) make up the majority of data at each of the lakes and most of the maxima and minima for specific nutrients are contained within those data sets. There does not appear to be any trend in the data over time.

Data on total phosphorus concentration, $\left[\mathbf{P}_{\mathrm{T}}\right]$, are available for all of the lakes, however, Mercer Lake 
contains the most complete set of $\left[\mathrm{P}_{\mathrm{T}}\right]$ data. Kavanagh (1973) recorded the lowest concentration, $.004 \mathrm{mg} / \mathrm{L}$, in June 1971 and Bryant (1979) recorded the highest concentration, $.355 \mathrm{mg} / \mathrm{L}$, in september 1978. The two $1992\left[\mathrm{P}_{\mathrm{T}}\right]$ values of $.02 \mathrm{mg} / \mathrm{L}$ are below the mean of $.035 \mathrm{mg} / \mathrm{L}$ for summer surface samples. The $1992\left[\mathrm{P}_{\mathrm{T}}\right]$ values at Munsel Lake, $.01 \mathrm{mg} / \mathrm{L}$ and $<.01 \mathrm{mg} / \mathrm{L}$, are higher than values obtained by Kavanagh (1973) for similar dates but are less than the mean of .023 mg/L for all summer surface samples. For Woahink Lake, there are no historic summer $\left[P_{T}\right]$ values with which to compare the two 1992 values of $<.01 \mathrm{mg} / \mathrm{L}$.

In Mercer Lake, data collected since 1938 strongly suggest that nutrients were being released from the sediment during the period of thermal stratification. All historic data showed that hypolimnetic anoxia occurred during summer stratification. Additionally, Griffith and Yeoman's (1938) data showed that anoxic conditions occurred simultaneously with greatly increased alkalinity. Kavanagh's (1973) data showed that the hypolimnetic $\left[\mathrm{NO}_{3}{ }^{-}\right]$decreased to $0.0 \mathrm{mg} / \mathrm{L}$ during stratification in 1971. Bryant's (1979) data showed that hypolimnetic $\left[P_{T}\right]$ were two to seven times higher than surface $\left[P_{T}\right]$ during the summer of 1978 . In 1991, the following conditions were observed in the hypolimnion: anoxia, the odor of $\mathrm{H}_{2}$ S from water samples, an increase in redox potential from $63 \mathrm{mv}$ to $-171 \mathrm{mv}$ with increasing depth, an increase in conductivity from $84 \mu$ mhos $\mathrm{cm}^{-1}$ to $150 \mu \mathrm{mhos}$ 
$\mathrm{cm}^{-1}$ with increasing depth, and a doubling of the alkalinity concentration compared to the epilimnion. All of these data are indicative of strong reducing conditions, confirmed by the 1991 redox data, where nutrients and ions can be mobilized. Under these conditions, $\mathrm{NO}_{3}^{-}$is reduced to $\mathrm{NH}_{4}^{+}$, adsorbed phosphate is released from the sediment, and, if sufficient amounts of Fes are precipitated, the accumulated hypolimnetic phosphate may remain in solution during fall turnover (Wetzel 1983).

In 1991, conditions similar to those listed above were also observed in Munsel Lake. Griffith and Yeoman's (1938) data documented hypolimnetic anoxia and the simultaneous occurrence of increased alkalinity. Kavanagh's (1973) data showed that $\left[\mathrm{NO}_{3}{ }^{-}\right]$in the epilimnion decreased to $0.0 \mathrm{mg} / \mathrm{L}$ from July through November 1971. Larson's (1974) data showed that hypolimnetic $\left[\mathrm{NO}_{3}{ }^{-}\right]$and $\left[\mathrm{NH}_{4}{ }^{+}\right]$were one to seven times greater than epilimnetic concentrations, and that hypolimnetic $\left[\mathrm{NO}_{3}^{-}\right]$decreased as the summer progressed. However, Larson's (1974) $\left[\mathrm{P}_{\mathrm{T}}\right]$ did not change with depth. Although not confirmed by Larson's (1974) data, these data suggest that nutrients and ions were also mobilized from the sediment of Munsel Lake.

Using the available data, the following ratios were calculated, $\left[\mathrm{N}_{\mathrm{T}}\right]:\left[\mathrm{P}_{\mathrm{T}}\right]$ and $\left[\mathrm{NH}_{4}-\mathrm{N}\right]+\left[\mathrm{NO}_{3}-\mathrm{N}\right]:\left[\mathrm{PO}_{4}-\mathrm{P}\right]$. These ratios may give some indication of phosphorus or nitrogen limitation for algal growth (Dr. Richard Petersen personal 
communication). The rationale for calculating these ratios is based on the widely quoted stoichiometry for the major elements, by atoms, in rapidly growing phytoplankton. Phytoplankton take up macronutrients in the following ratio 106C: 16N: 1P (Harris 1986). Conversion of these atom ratios to weight ratios gives $7 \mathrm{~N}$ : 1P. Ratios less than 7 indicate surplus phosphorus while ratios greater than 7 indicate surplus nitrogen. of all the major nutrients necessary for biological growth, phosphorus is the least plentiful in the environment and most often limits biological productivity in lakes (Wetzel 1983).

simultaneously collected data for calculation of $\left[\mathrm{N}_{\mathrm{T}}\right]$ : $\left[\mathrm{P}_{\mathrm{T}}\right]$ and $\left[\mathrm{NH}_{4}-\mathrm{N}\right]+\left[\mathrm{NO}_{3}-\mathrm{N}\right]:\left[\mathrm{PO}_{4}-\mathrm{P}\right]$ ratios were limited and the results were contradictory. At Mercer and Woahink Lakes, the few results of $\left[\mathrm{N}_{\mathrm{T}}\right]:\left[\mathrm{P}_{\mathrm{T}}\right]$ ratios suggested nitrogen or phosphorus limitation on different dates. At Munsel Lake, five of the $\operatorname{six}\left[\mathrm{N}_{\mathrm{T}}\right]:\left[\mathrm{P}_{\mathrm{T}}\right]$ calculations showed surplus $\left[\mathrm{P}_{\mathrm{T}}\right]$. These results are supported by Kavanagh's (1973) data for Munsel Lake which showed that epilimnetic $\left[\mathrm{NO}_{3}-\mathrm{N}\right]$ was 0.0 $\mathrm{mg} / \mathrm{L}$ from July through November 1971. However, calculations of $\left[\mathrm{NH}_{4}-\mathrm{N}\right]+\left[\mathrm{NO}_{3}-\mathrm{N}\right]:\left[\mathrm{PO}_{4}-\mathrm{P}\right]$ ratios consistently showed surplus $\left[\mathrm{N}_{\mathrm{T}}\right]$ in all three lakes.

True bioassays have only been completed at Woahink Lake (Maloney et al. 1972). Laboratory experiments indicated that while phosphorus was initially limiting for algal growth, carbon and nitrogen became limiting when sufficient 
phosphorus was present. Seven of my nine calculations for $\left[\mathrm{N}_{\mathrm{T}}\right]:\left[\mathrm{P}_{\mathrm{T}}\right]$ or $\left[\mathrm{NH}_{4}-\mathrm{N}\right]+\left[\mathrm{NO}_{3}-\mathrm{N}\right]:\left[\mathrm{PO}_{4}-\mathrm{P}\right]$ ratios support those results.

\section{PRIMARY PRODUCTIVITY}

Larson and Salinas (1991 unpublished) measured phytoplankton primary productivity at the study lakes during the summer and fall of 1991. Estimates of the rate of primary productivity as reported by Kavanagh (1973) for Mercer and Munsel Lakes and by Larson (1970a) for Woahink Lake are summarized and compared with data from Larson and Salinas (1991 unpublished) in Tables V, VI, and VII. As previously noted, the primary productivity methods used by Larson and Salinas (1991 unpublished) are the same as the methods used from 1968 to 1972 by Larson (1970a) and by

\section{TABLE V}

MERCER LAKE: PRIMARY PRODUCTIVITY (mg $\left.C \mathrm{~m}^{-2} \mathrm{~h}^{-1}\right)$

\begin{tabular}{||l|c|c|c|}
\hline & $\begin{array}{c}\text { Jul.-Sep. } \\
1970\end{array}$ & $\begin{array}{c}\text { Feb.-Jan. } \\
1971-1972\end{array}$ & $\begin{array}{c}\text { Sep. } \\
1991\end{array}$ \\
\hline Count & 2 & 11 & 1 \\
\hline Minimum & 39.0 & 4.0 & \\
\hline Maximum & 87.0 & 47.0 & $146.1^{(1)}$ \\
\hline Mean & 63.0 & 28.1 & \\
\hline
\end{tabular}

Note: "September 13, 1991 
TABLE VI

MUNSEL LAKE: PRIMARY PRODUCTIVITY (mg C m $\left.\mathrm{m}^{-2} \mathrm{~h}^{-1}\right)$

\begin{tabular}{|l|c|c|c|}
\hline & $\begin{array}{c}\text { Jul.-Sep. } \\
1970\end{array}$ & $\begin{array}{c}\text { Feb.-Jan. } \\
1971-1972\end{array}$ & $\begin{array}{c}\text { Aug.-Sep. } \\
1991\end{array}$ \\
\hline Count & 2 & 11 & 2 \\
\hline Minimum & 32.0 & 8.0 & $63.5^{(1)}$ \\
\hline Maximum & 40.0 & 45.0 & $97.4^{(2)}$ \\
\hline Mean & 36.0 & 28.0 & 80.5 \\
\hline
\end{tabular}

Note: "August 7, 1991; (2) September 3, 1991

TABLE VII

WOAHINK LAKE: PRIMARY PRODUCTIVITY (mg $c \mathrm{~m}^{-2} \mathrm{~h}^{-1}$ )

\begin{tabular}{|l|c|c|c||}
\hline & $\begin{array}{c}\text { Jun.-Dec. } \\
1968\end{array}$ & $\begin{array}{c}\text { Feb.-Sep. } \\
1969\end{array}$ & $\begin{array}{c}\text { Aug.-Sep. } \\
1991\end{array}$ \\
\hline Count & 8 & 9 & 2 \\
\hline Minimum & 1.98 & 2.50 & $48.80^{(1)}$ \\
\hline Maximum & 37.05 & 45.96 & $81.97^{(2)}$ \\
\hline Mean & 19.91 & 21.01 & 65.39 \\
\hline
\end{tabular}

Note: (1) August 5, 1991; (2) September 4, 1991

Kavanagh (1973). It is difficult to make broad comparisons between years because of the small number of measurements from 1991. However, it is noteworthy that, at each lake, the maximum rate of primary productivity measured in 1991 is significantly higher than any previous measurement.

\section{CHLOROPHYLL $\underline{\text { a }}$}

Chlorophyll a samples have been analyzed since 1969 at Woahink Lake (Larson 1970a) and since 1971 at Mercer and 
Munsel Lakes (Kavanagh 1973). Those two researchers gathered the most comprehensive sets of chlorophyll a data to date by sampling monthly over the course of a year at numerous depths.

It is difficult to compare chlorophyll a values over time for a number of reasons. There may be great variations in the vertical and temporal distribution of phytoplanktonic biomass from season to season with shifts in species composition (Wetzel 1983). Temperature, turbulence, light climate, nutrients, and other variables also affect the distribution of phytoplankton. Samples collected during 1969-1971, 1978-1979, 1991, and 1992 were collected at discrete depths while samples collected in the 1980's were integrated. Both Larson (1970a) and Kavanagh (1973) analyzed chlorophyll a samples spectrophometrically while all subsequent samples were analyzed fluorometrically. Some of the fluorometric values were corrected for the presence pheophytin a, a chlorophyll degradation product, while others were not corrected.

Figure 12 shows a comparison of chlorophyll a concentrations for selected dates and comparable depths at Mercer Lake. Kavanagh (1973) measured chlorophyll a concentrations at five or more depths on eleven dates between February 14, 1971 and January 5, 1972 . Concentrations of chlorophyll a ranged approximately from 0 $\mu \mathrm{g} / \mathrm{L}$ to an all-time high of $55.5 \mu \mathrm{g} / \mathrm{L}$ at $6 \mathrm{~m}$ on June 9, 


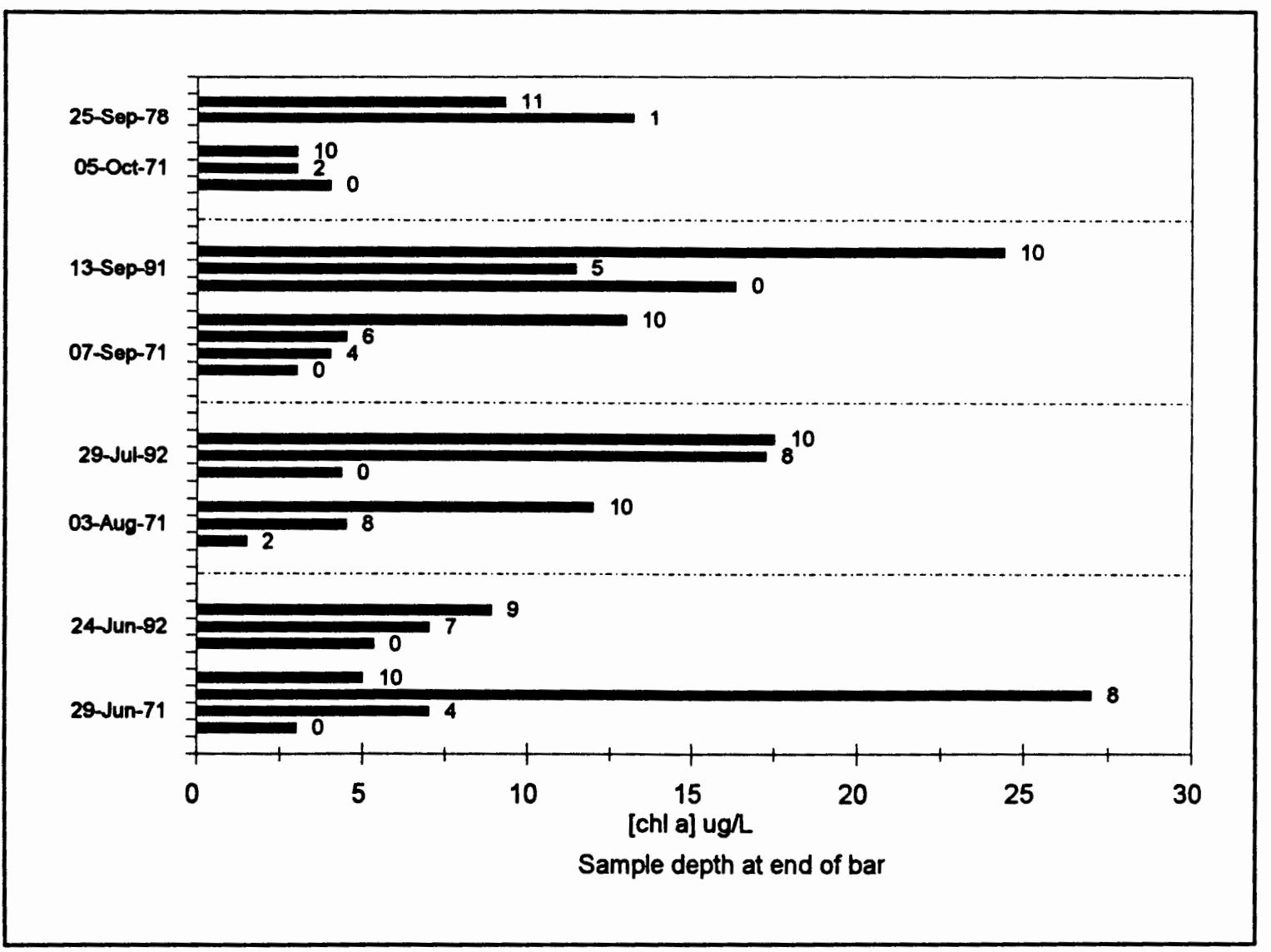

Figure 12. Comparison of chlorophyll a concentrations for similar dates over time at Mercer Lake. Sample depth at end of bar.

1971. In 1971, the chlorophyll maximum developed between 4 $\mathrm{m}$ and $6 \mathrm{~m}$ during June and between $8 \mathrm{~m}$ and $10 \mathrm{~m}$ during July to september. From June through september 1971 for all depths, the mean chlorophyll a concentration was approximately $7 \mu \mathrm{g} / \mathrm{L}$. Chlorophyll concentrations for 1991 and 1992 are two to five times greater than concentrations for comparable dates and depths from earlier years.

Figure 13 shows a comparison of chlorophyll a concentrations for selected dates and comparable depths at Munsel Lake. Kavanagh (1973) measured chlorophyll a 


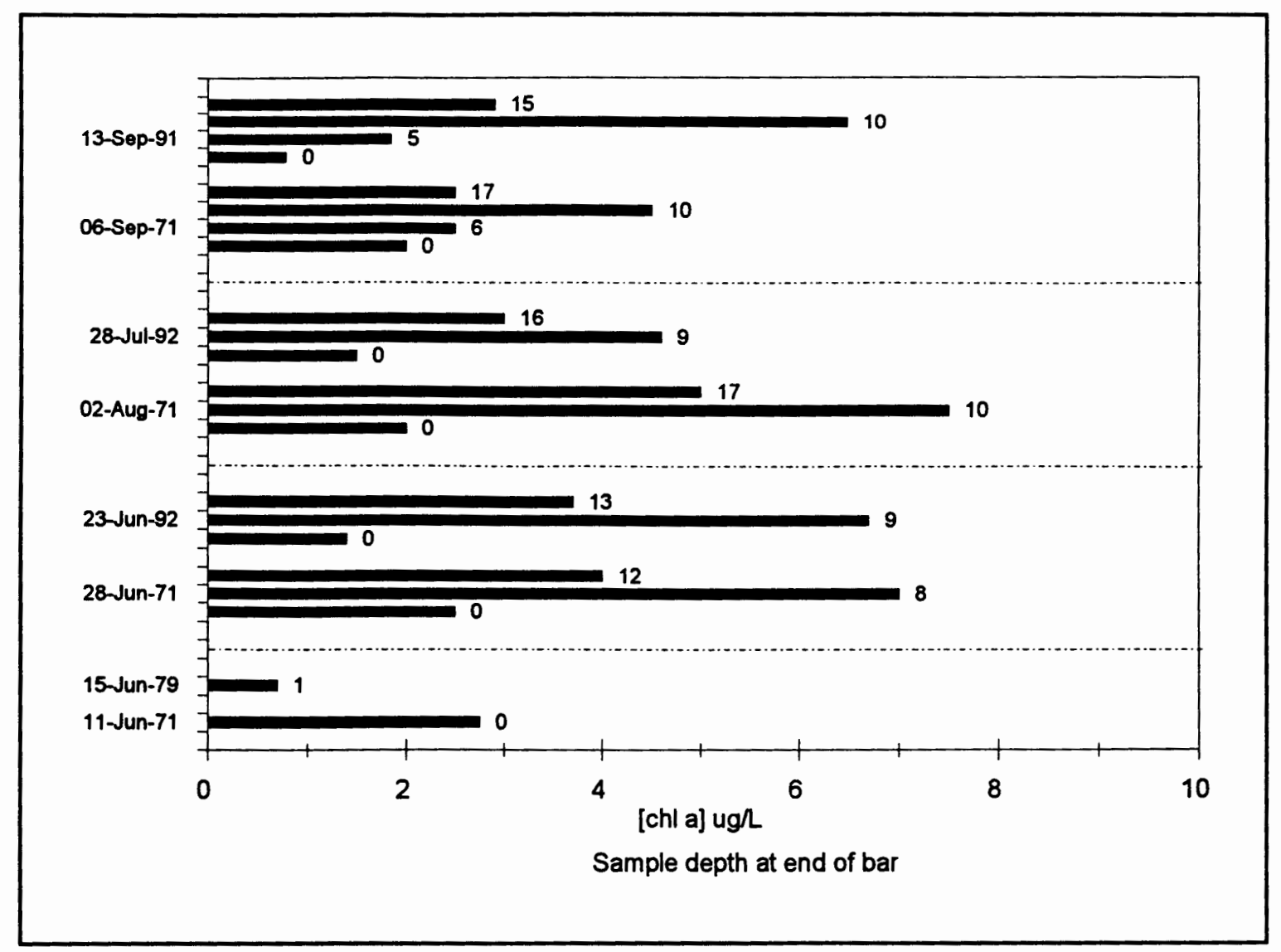

Figure 13. Comparison of chlorophyll a concentrations for similar dates over time at Munsel Lake. Sample depth at end of bar.

concentrations at seven or more depths on eleven dates between April 19, 1971 and January 4, 1972. Concentrations of chlorophyll a ranged approximately from $.5 \mu \mathrm{g} / \mathrm{L}$ to a high of $9 \mu \mathrm{g} / \mathrm{L}$ at $8 \mathrm{~m}$ on July 15, 1971. In 1971, the chlorophyll maximum developed at $8 \mathrm{~m}$ during June and deepened to $12 \mathrm{~m}$ by mid-September. From June through September 1971 for all depths, the mean chlorophyll a concentration was approximately $4 \mu \mathrm{g} / \mathrm{L}$. Chlorophyll a concentrations for comparable dates over time are similar although the 1971 values are consistently higher than values obtained in 
subsequent years.

Figure 13 shows a comparison of chlorophyll a concentrations for selected dates and comparable depths at Woahink Lake. Larson (1970a) measured chlorophyll a

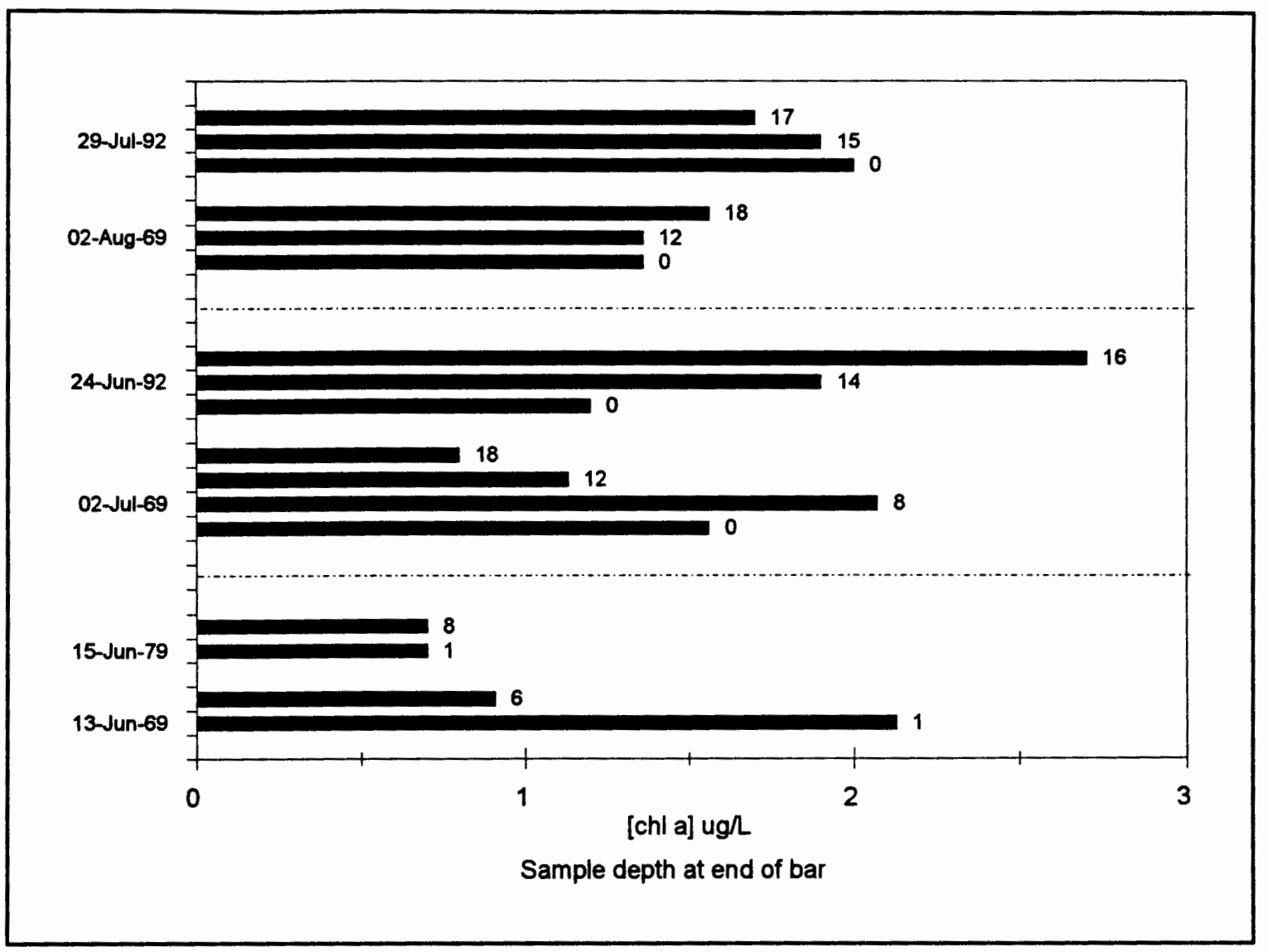

Fiqure 14. Comparison of chlorophyll a concentrations for similar dates over time at Woahink Lake. Sample depth at end of bar.

concentrations at two depths during April and May 1969 and at six depths on five dates between June and september 1969. Concentrations of chlorophyll a ranged from $0 \mu \mathrm{g} / \mathrm{L}$ to a high of $2.8 \mu \mathrm{g} / \mathrm{L}$ at $18 \mathrm{~m}$ on September 3, 1969. In 1969, the chlorophyll maximum developed at the surface during June and deepened to $18 \mathrm{~m}$ by september 3 . On September 28, 1969 the 
chlorophyll maximum was again present at the surface. From June through september 1969 for all depths, the mean chlorophyll a concentration was $1.4 \mu \mathrm{g} / \mathrm{L}$. Chlorophyll a concentrations for comparable dates between years are very similar. The 1992 maximum value of $2.7 \mu \mathrm{g} / \mathrm{L}$ measured at 16 $m$ on June 24,1992 is close to the maximum value for 1969 measured in september at $18 \mathrm{~m}$.

\section{PHYTOPLANKTON}

The three lakes contain a diverse assemblage of phytoplankton. Since the first samples were collected in 1969, 144 species have been identified. They represent 6 phyla, 3 sub-phyla, 13 orders, and 35 families. A species list for each lake is presented in Appendix D. All results of phytoplankton analyses for the lakes originally listed the phytoplankton only by genus and species. This author has compiled the species list into phylum, sub-phylum, order, and family categories following Prescott (1978). woahink had the greatest number of identified species which may be related to sampling frequency: more sampling might have increased the probability of enumerating more species. A sample collected in 1969 at Woahink Lake by Larson (1970a) represents the earliest phytoplankton sample from the three lakes studied here. Analysis of the sample, by Dr. Harry Phinney at O.S.U., provided a list of the major genera. The next analyses of phytoplankton samples were 
conducted by Robert McHugh (unpublished) of the oregon Department of Environmental Quality who analyzed five samples collected from the three lakes between 1972 and 1979. There was no record of sample depth or collection method and only the most numerous species were identified. Estimates of biovolume or density were not made for samples collected before 1981. Recent data for this study were from analyses of samples collected by Larson and Salinas (1991 unpublished) and by Daggett and Petersen (1993).

Jim Sweet has analyzed all samples collected since 1981 following the methods described in Appendix A. The phytoplankton in those samples were identified to species if possible and the following estimates were calculated: density (number per $\mathrm{mL}$ ), percent density, biovolume $\left(\mu \mathrm{m}^{3} \mathrm{~mL}^{-1}\right)$, percent biovolume, trophic state index, and diversity index (Shannon-Weaver diversity index log base 2). Additionally, Sweet calculated similarity indices for all samples. A similarity index compares each species' relative abundance in two different samples. The resulting value is a number between 0 , for dissimilar samples, and 100, for identical samples. Typical duplicate samples often give a similarity index of 75 , which would be considered very similar (Sweet personal communication). This type of index can be useful in comparing phytoplankton communities between samples collected at different depths or dates. Sweet (Johnson et al. 1985, Sweet 1986, Sweet personal 
communication) has suggested that certain species of phytoplankton may serve as trophic state indicator species. oligotrophic species include the chrysophytes Chromulina sp., Cyclotella stelligera, Tabellaria fenestrata, and Tabellaria flocculosa; the cyanophyte Anacystis marina; and, usually, the chlorophytes oocystis pusilla and sphaerocystis schroeteri. A primarily mesotrophic but sometimes eutrophic phytoplankton is the chrysophyte Melosira granulata. Mesotrophic to eutrophic species are the chrysophytes Asterionella formosa and Fragilaria crotonensis. Eutrophic species are the cyanophytes Anabaena circinalis, Anabaena flos-aquae, Anabaena sp. and Oscillatoria sp.

In an effort to better characterize the phytoplankton populations, a number of indices for diversity and evenness have been calculated. In community ecology, the term diversity is composed of two parts: (1) species richness, which is the total number of species; and (2) evenness, which is the relative abundance of species (Ludwig and Reynolds 1988). Diversity indices typically combine species richness and evenness into a single value. Their interpretation may be difficult, however, because a given value may result from various combinations of species richness and evenness (Ludwig and Reynolds 1988). The following four indices have been calculated for all phytoplankton samples collected since 1981 and are presented in the subsequent discussion of results for each lake. The 
indices are Hill's diversity indices, N1 and N2; Hill's modified evenness ratio, E5; and the Shannon-Weaver diversity index, $\mathrm{H}^{\prime}$. The first three indices are easily interpreted and are included on the advice of Ludwig and Reynolds (1988). The fourth, $\mathrm{H}^{\prime}$, is included because, although more ambiguous, it is the most commonly used index and is included in the calculations for N1 and E5. Refer to Ludwig and Reynolds (1988) for the specific equations and the rationale behind their construction. The indices were calculated using both density (number $\mathrm{mL}^{-1}$ ) and biovolume $\left(\mu \mathrm{m}^{3} \mathrm{~mL}^{-1}\right)$ data. Index values calculated from both types of data may provide more insight into the phytoplankton communities' distribution.

Hill's N1 and N2 are both diversity indices. The units are in number of species and, as the index values increase, less weight is placed on rare species. N1 describes the number of abundant species and $\mathrm{N2}$ describes the number of very abundant species (Ludwig and Reynolds 1988). For example, an $N 1$ value of 12.2 indicates that there were 12.2 abundant species present in the sample.

Hill's modified ratio $\mathrm{E5}$ is an evenness index. Numbers in the index range between 0 and 1 and are relatively unaffected by species richness. As the index number approaches 0 a single species becomes more dominant in a community (Ludwig and Reynolds 1988).

The Shannon-Weaver diversity index, $\mathrm{H}^{\prime}$, is one of the 
most commonly employed ecological indices (Harris 1986, Ludwig and Reynolds 1988). Values in the diversity index generally fall between 1.0 and 4.5 , with larger numbers usually indicating greater species diversity (richness and evenness).

Ecologists continue to use diversity indices because they provide some indication of ecological diversity (Harris 1986). Margalef (1980) notes that the diversity of phytoplankton is higher in oligotrophic than in eutrophic waters.

A summary of all of the phytoplankton biovolume data for samples collected since 1981 is presented in Table VIII. The results of all phytoplankton analyses are compiled in Appendix E.

TABLE VIII

SUMMARY OF TOTAL BIOVOLUME DATA FOR PHYTOPLANKTON SAMPLES COLLECTED SINCE 1981. UNITS OF $\left(\mu \mathrm{m}^{3} \mathrm{~mL}^{-1}\right)$

\begin{tabular}{||l|c|c|c|}
\hline & Mercer Lake & Munsel Lake & Woahink Lake \\
\hline Count & 13 & 16 & 23 \\
\hline Minimum & 148746 & 16352 & 12494 \\
\hline Maximum & 1046075 & 439861 & 136085 \\
\hline Mean & 384655 & 112319 & 60497 \\
\hline Median & 305943 & 72895 & 60084 \\
\hline
\end{tabular}

Mercer Lake Phytoplankton

Phytoplankton samples from Mercer Lake have been 
collected and analyzed since 1972 (see Table II). Figure 15 shows the total biovolume and total density of all phytoplankton samples collected at Mercer Lake since 1981. Figure 16 shows the biovolume of each Mercer Lake phytoplankton sample by phylum.

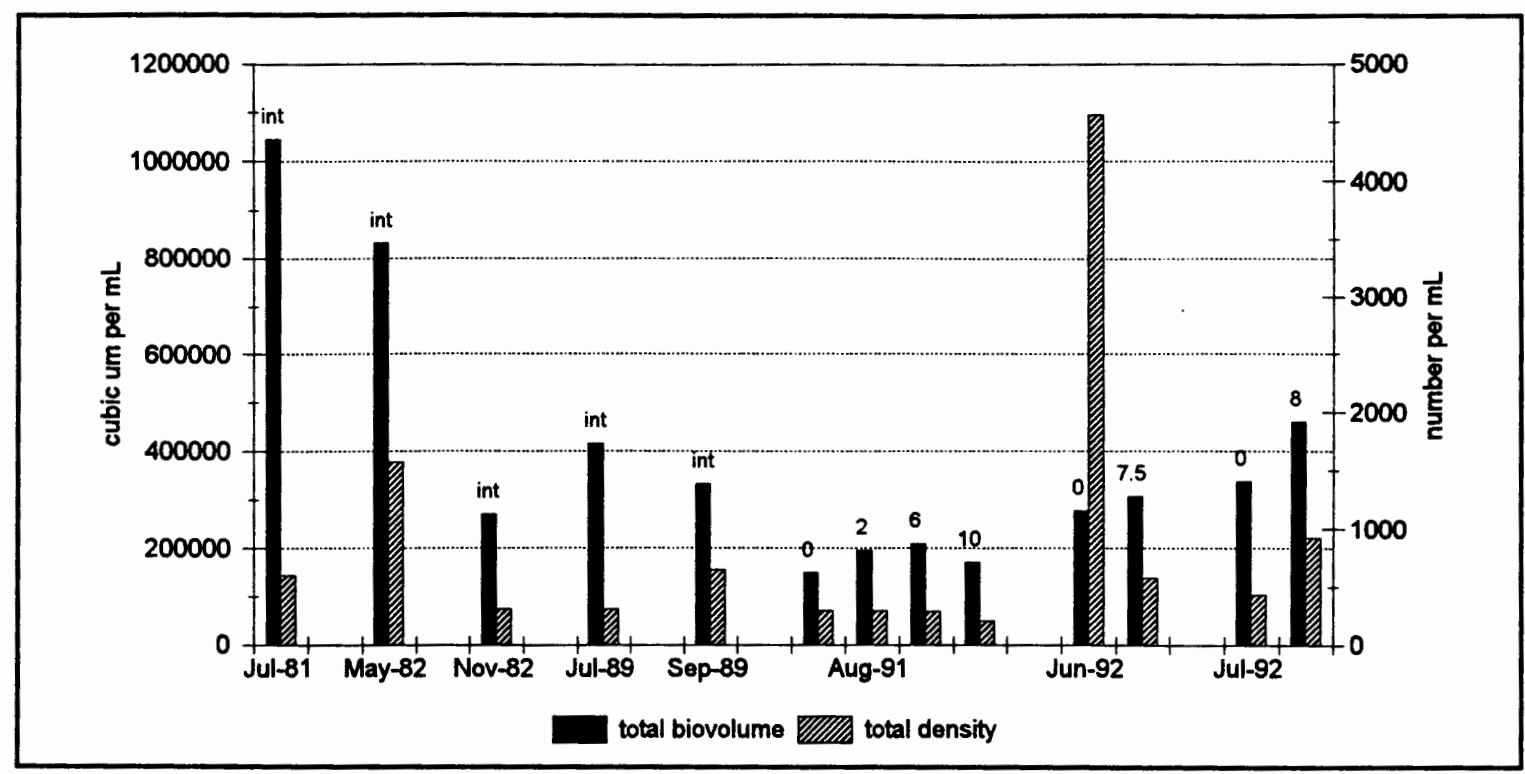

Fiqure 15. Total biovolume and total density for all phytoplankton samples collected at Mercer Lake since 1981. Sample depth above bar.

Generally, in descending order of biovolume, Mercer Lake samples have been composed of chrysophytes, cryptophytes, and chlorophytes. Periodically, cyanophytes have made up a significant portion of a sample's total biovolume. Euglenophytes have appeared occasionally and pyrrophytes showed up for the first time in 1992 .

over time, the phytoplankton community in Mercer Lake has been dominated by chrysophytes. Two of the samples from the early $1980^{\prime} \mathrm{s}$ contained chrysophytes at biovolumes 


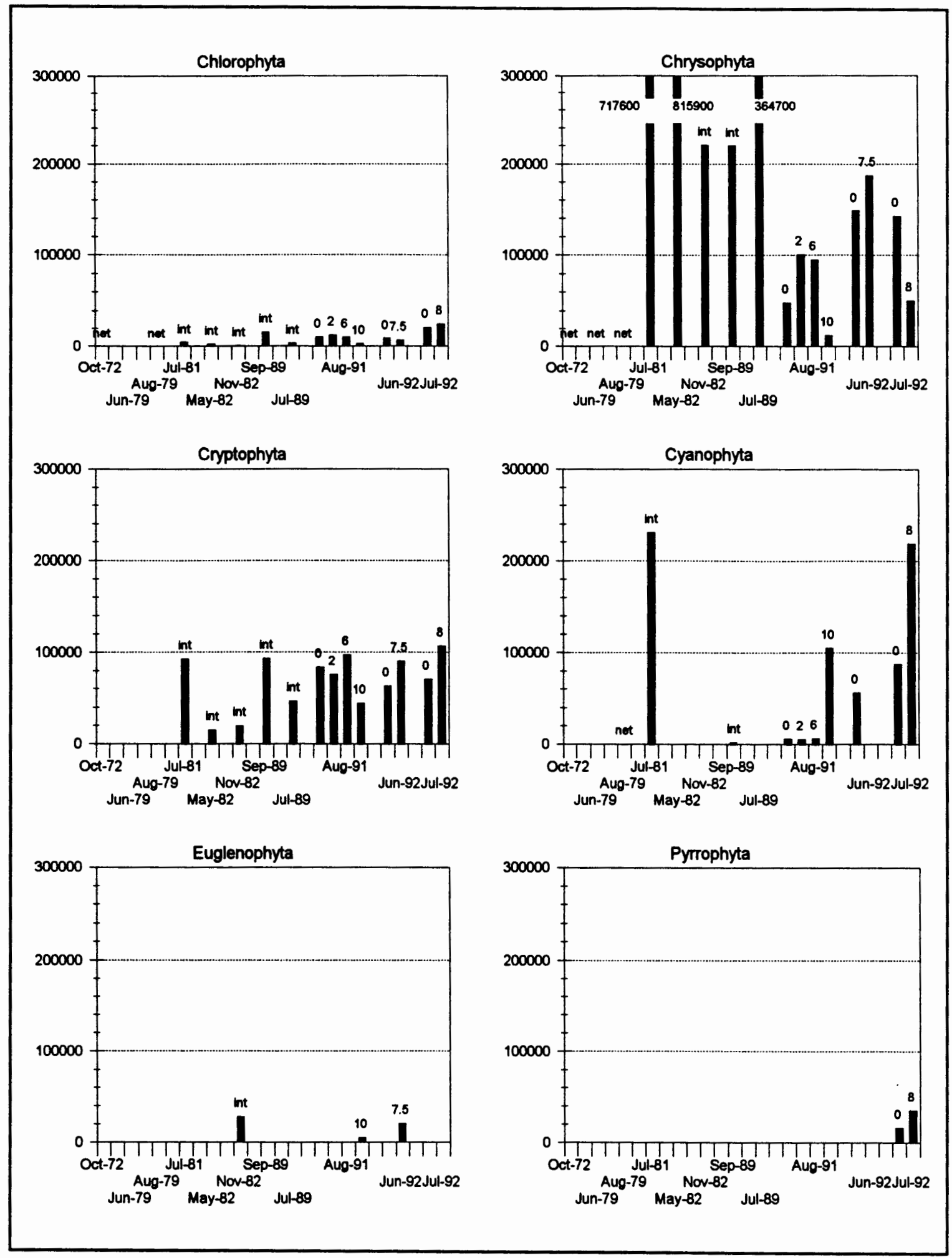

Fiqure 16. Biovolume of Mercer Lake phytoplankton by phylum. Units of $\mu \mathrm{m}^{3} \mathrm{~mL}^{-1}$. Sample depth above bar. 
greater than $800,000 \mu \mathrm{m}^{3} \mathrm{~mL}^{-1}$, by far the greatest sample or phylum biovolumes recorded at any of the three lakes. Asterionella formosa, Fragilaria crotonensis, and Tabellaria fenestrata have been the dominant chrysophyte species.

The samples from 1991 and 1992 were more evenly dominated by chrysophytes and cryptophytes. Fragilaria crotonensis and Tabellaria fenestrata were again the dominant chrysophytes. The dominant cryptophyte has been Cryptomonas erosa.

In a number of summer samples cyanophytes, Anabaena circinalis or Oscillatoria sp., made up a significant percentage of the sample biovolume. Generally, the most common chlorophyte based on biovolume has been chlamydomonas sp. In July 1992 samples, the pyrrophyte Peridinium cinctum appeared for the first time.

Figure 17 shows the distribution of trophic indicator species. Out of the thirteen samples collected since 1981, nine of them contain 30-90\% by biovolume of species that would be considered mesotrophic or eutrophic. The biovolume percentage of eutrophic species was much greater in the 1992 samples.

Figure 18 displays the diversity and evenness indices for samples collected since 1981. The data on the two graphs follow the same general pattern. Based on density and biovolume data the most diverse sample was an integrated sample collected in November 1982. 


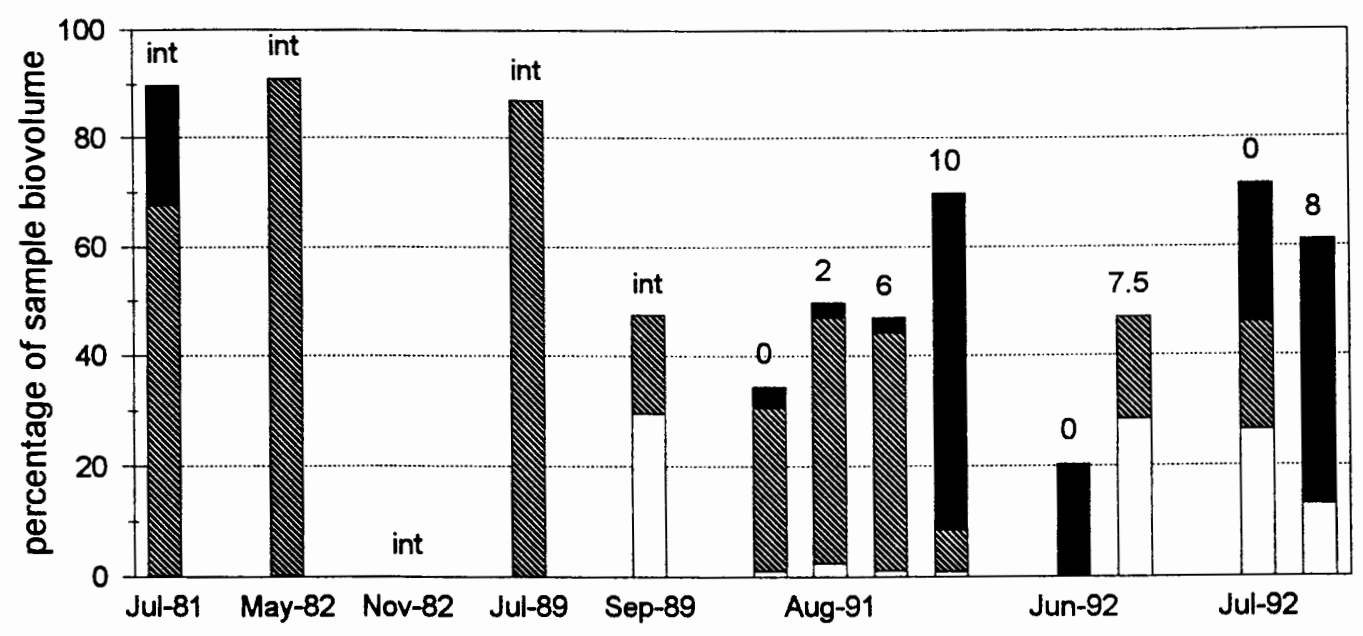

$\square$ oligo meso-eutro $\square$ eutro

Fiqure 17. Trophic indicator species in Mercer Lake phytoplankton samples as a percentage of total sample biovolume. Sample depth above bar.

A comparison was made between all eight of the depth integrated and surface samples using the similarity index. The values ranged from 7 to 73 . The sample collected from just below the surface on June 24,1992 showed the least similarity with any of the other selected samples. On that date, a chrysophyte, Chrysochromulina-like made up $88 \%$ of the phytoplankton density. The most similar samples were those collected in July of 1981, 1989, and 1991. An integrated sample collected July 18, 1981 and an integrated sample collected July 6, 1989 gave a value 73. A comparison of the 1981 sample with one collected just below the surface on July 29, 1992 gave a value of 62 . 


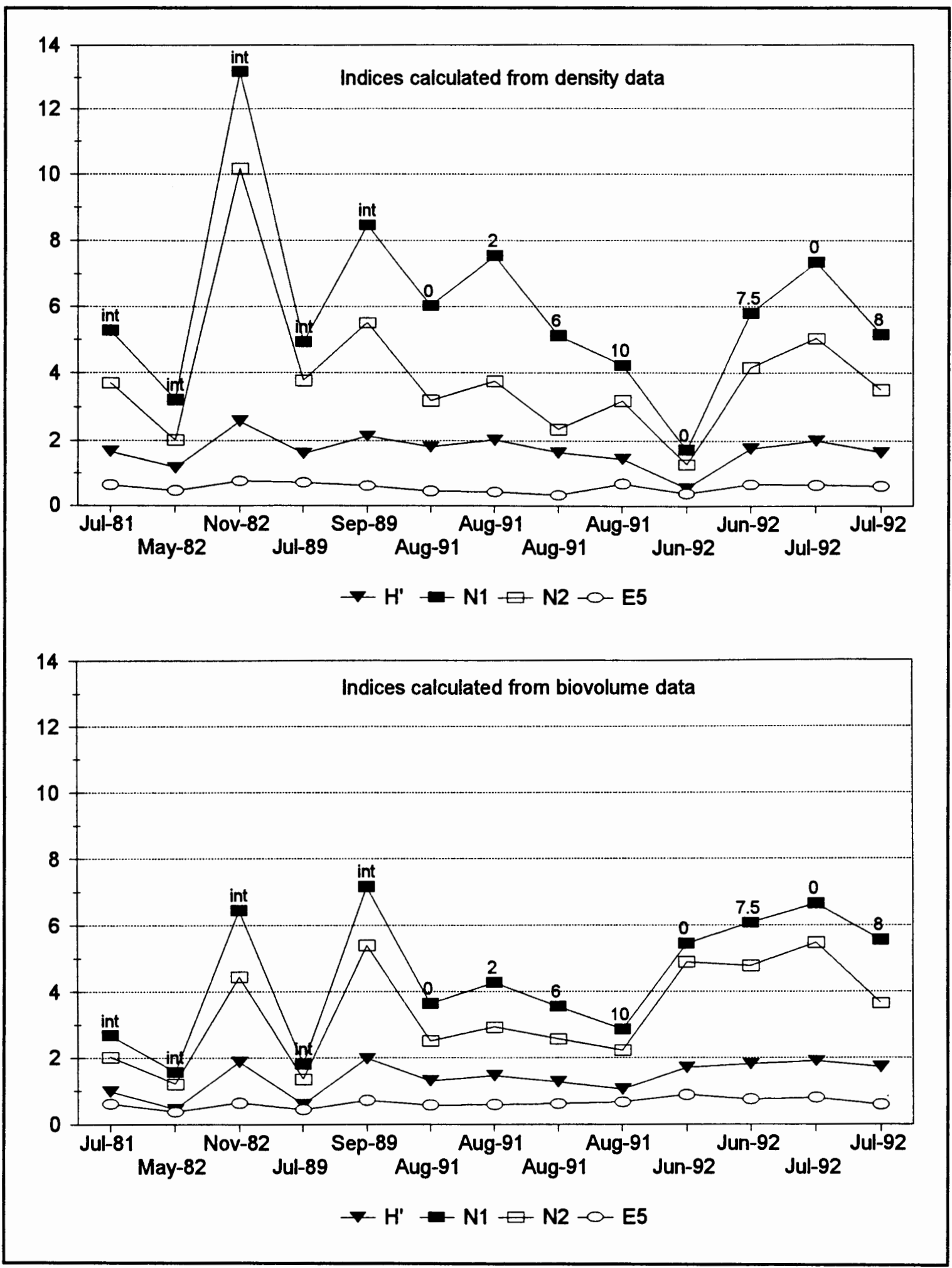

Fiqure 18. Diversity and evenness indices based on density and biovolume for Mercer Lake phytoplankton samples. Depth above top series. 
Munsel Lake Phytoplankton

Munsel Lake phytoplankton samples have been collected and analyzed infrequently since 1973 (see Table II) with ten of the seventeen samples collected during the summer of 1991. Figure 19 shows the total biovolume and total density of each Munsel Lake phytoplankton sample. Figure 20 shows the biovolume of each Munsel Lake phytoplankton sample by phylum.

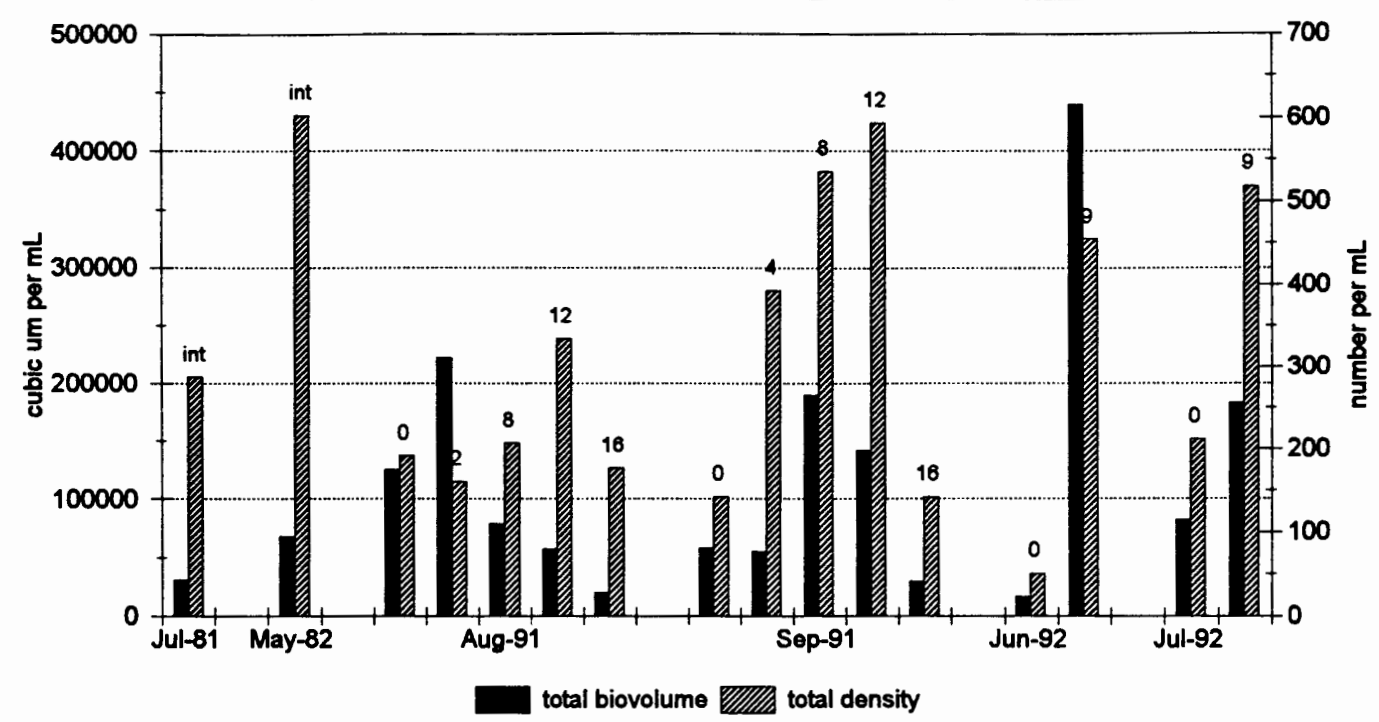

Figure 19. Total biovolume and total density for all phytoplankton samples collected at Munsel Lake since 1981. Sample depth above bar.

The Munsel Lake samples show a less consistent composition than the Mercer Lake samples. Based on biovolume, chrysophytes have generally been the predominant phyla. On different dates and at different depths, cyanophytes, cryptophytes, and pyrrophytes have dominated a given sample. Euglenophytes have never appeared in any of 


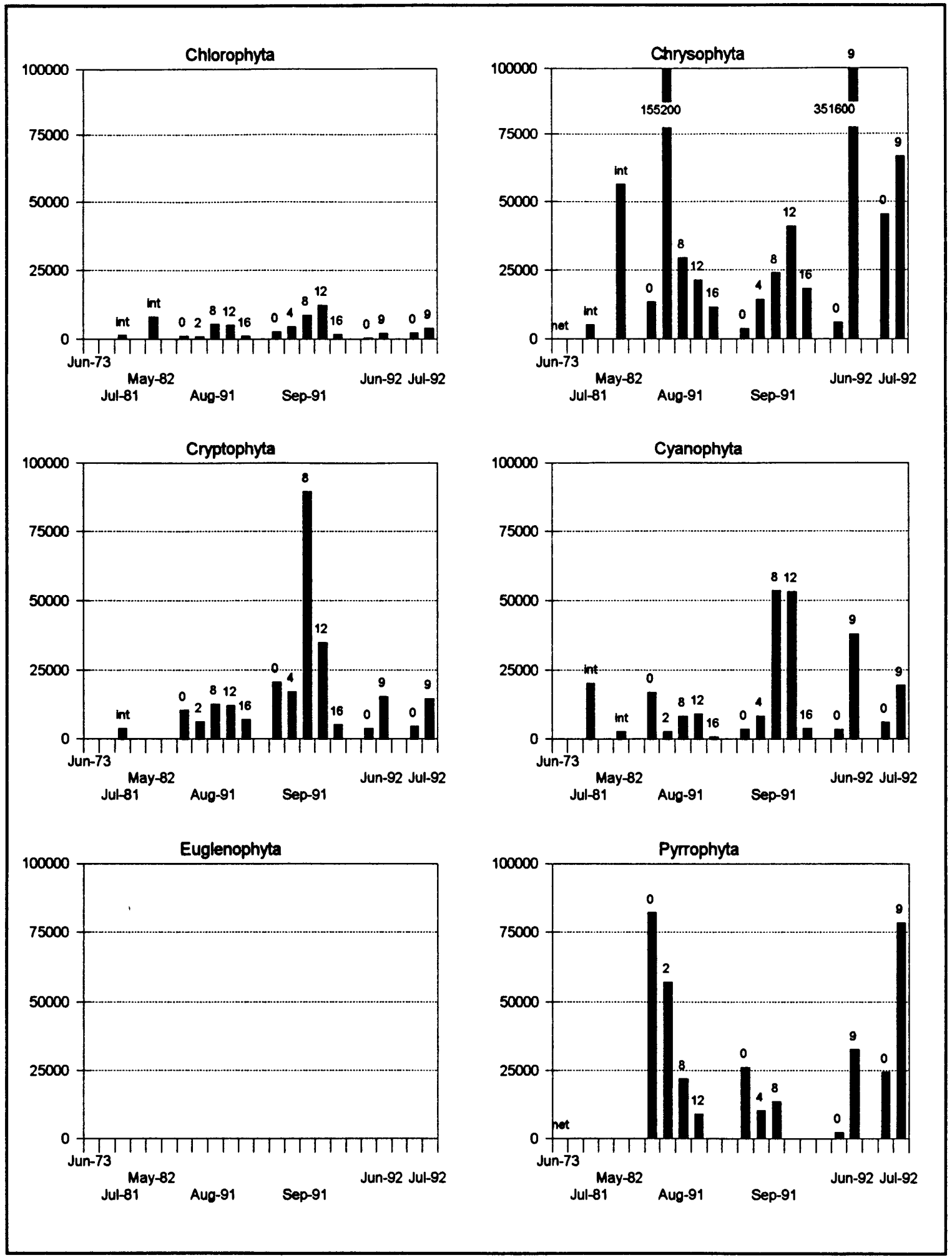

Fiqure 20. Biovolume of Munsel Lake phytoplankton by phylum. Units of $\mu \mathrm{m}^{3} \mathrm{~mL}^{-1}$. Sample depth above bar. 
the samples.

The dominant chrysophytes in Munsel Lake have been Cyclotella stelligera, Cyclotella comta, and Asterionella formosa. Cyclotella stelligera is commonly found along with the cyanophyte Anacystis marina (Sweet personal communication). The greatest biovolume of any one species was $309000 \mu \mathrm{m}^{3} \mathrm{~mL}^{-1}$ of Cyclotella comta in a sample collected from $9 \mathrm{~m}$ in late June 1992.

Dominant species of cyanophytes have been Anacystis marina and Anabaena flos-aquae. The dominant cryptophytes have been Cryptomonas erosa and Rhodomonas minuta. The dominant species of Pyrrohphyta have been Peridinium cinctum and Gymnodinium sp. Although always present as a small percentage of sample biovolume, the dominant chlorophytes have been Crucigenia tetrapedia, Nephrocytium sp., and Chlamydomonas sp.

As discussed earlier, historically, the dissolved oxygen profiles measured after summer stratification show a characteristic positive heterograde shape. This phenomenon existed in June and July of 1992 and phytoplankton samples collected in the thermocline at the depth of maximum oxygen concentration contained large biovolumes of several phyla. At $9 \mathrm{~m}$ on June 23, 1992, 70\% of the phytoplankton biovolume was composed of the chrysophyte cyclotella comta. At $9 \mathrm{~m}$ on July 28, two species dominated the phytoplankton by biovolume: the pyrrophyte Peridinium cinctum accounted for 
35\% and Cyclotella comta for 32\%. In 1991, only temperature measurements accompanied the collection of phytoplankton samples. It could be assumed that an oxygen profile similar to that observed in late July 1992 was also present on August 7, 1991. A sample collected on that date at $8 \mathrm{~m}$ was composed of the pyrrophyte Gymnodinium sp. at $28 \%$, the chrysophyte Asterionella formosa at 21\%, and the cryptophyte Cryptomonas erosa at $16 \%$. It is not clear from these few samples if there was a single phylum or species of phytoplankton that was primarily responsible for the seasonally observed metalimnetic oxygen maxima.

The presence of large biovolumes of phytoplankton in the thermocline is not unusual for a number of reasons. Biomass accumulations occur in locations where certain environmental conditions are met. Peridinium cinctum, Gymnodinium sp., and Cryptomonas erosa are able to migrate vertically via flagella and may have migrated into the metalimnion. Sedimentation velocities decrease in the denser metalimnion and the chrysophytes may have sedimented out of the surface layer and accumulated at the thermocline (Harris 1986).

Figure 21 shows the distribution of trophic indicator species. The samples collected since 1981 contain oligotrophic, mesotrophic to eutrophic, and eutrophic species in descending order of percentage of sample biovolume. There was a decrease in the biovolume percentage 


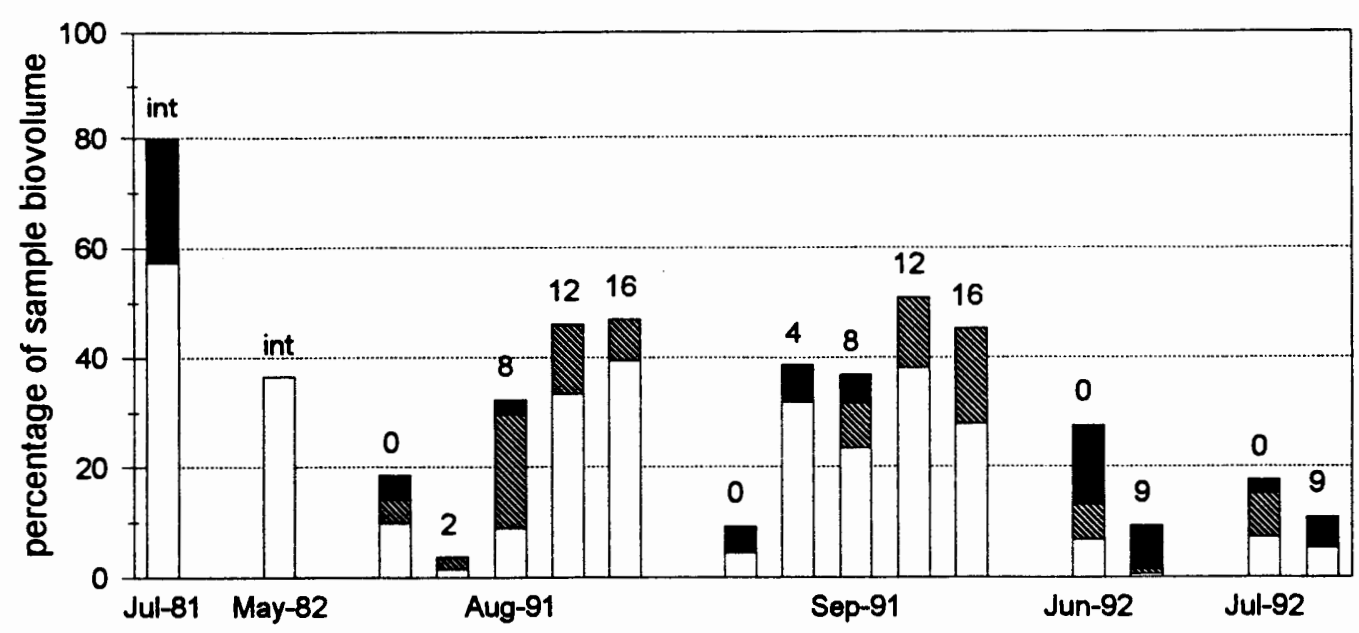

\section{oligo meso-eutro eutro}

Fiqure 21. Trophic indicator species in Munsel Lake phytoplankton samples as a percentage of total sample biovolume. Sample depth above bar.

of oligotrophic indicator species in the 1992 samples.

Figure 22 shows the diversity and evenness indices for Munsel Lake phytoplankton samples. The most diverse samples based both on density and biovolume were collected at the surface in June 1992 .

The similarity index was used to compare all six of the depth integrated and surface samples collected since 1981. The values ranged from 4 to 59. The integrated sample collected on May 1, 1982 showed the least similarity with any of the other selected samples which were all collected during the summer. The greatest similarities were between samples collected in July 1981, August 1991, and July 1992. An integrated sample collected July 20, 1981 and 


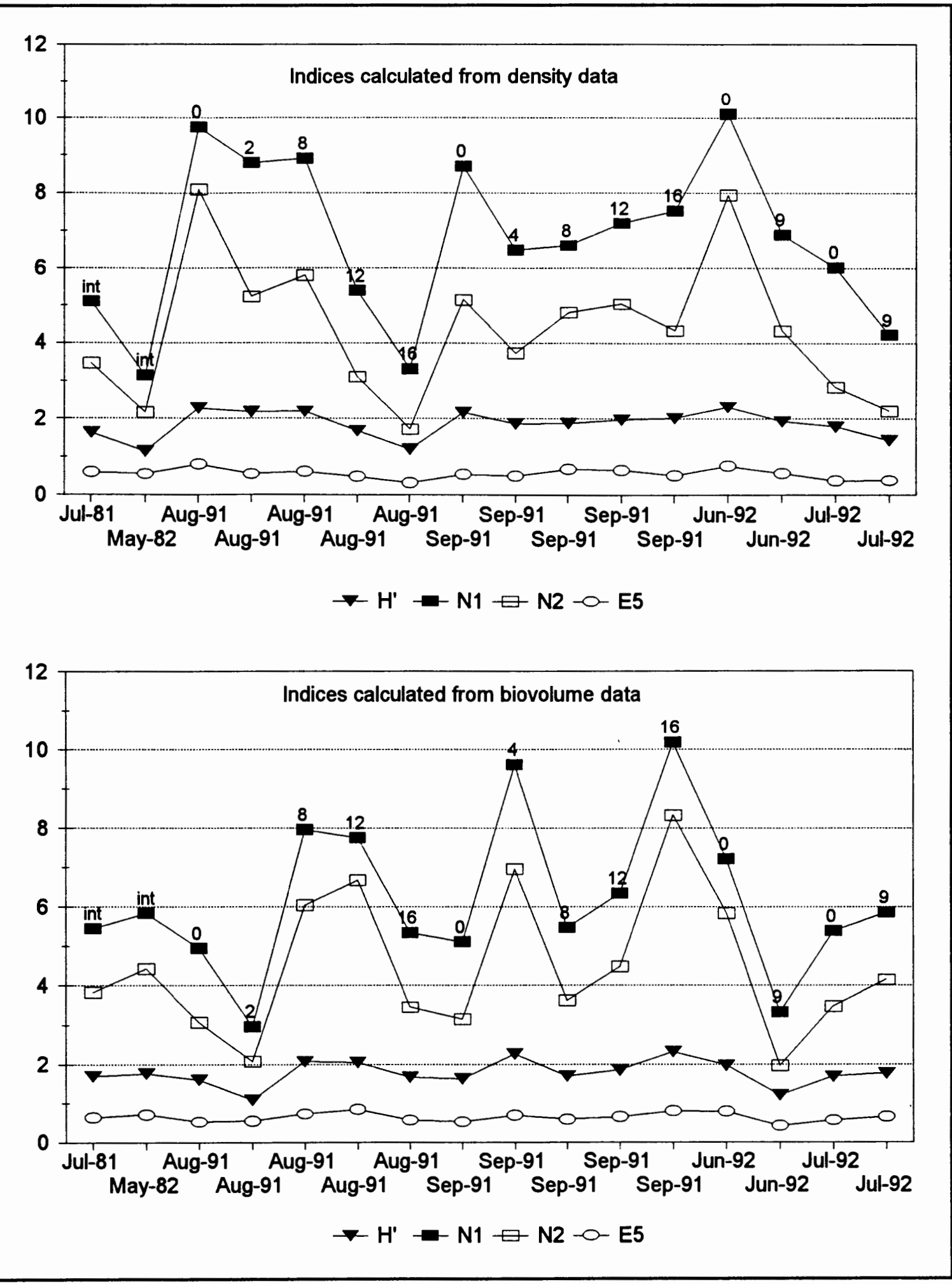

Figure 22. Diversity and evenness indices based on density and biovolume for Munsel Lake phytoplankton samples. Depth above top series. 
a sample collected just below the surface on July 28, 1992 gave a value 59. Comparison of the July 20, 1981 sample with one collected just below the surface on August 7, 1991 gave a value of 57 .

\section{Woahink Lake Phytoplankton}

Woahink Lake phytoplankton samples have been collected and analyzed since 1972 (see Table II). Figure 23 shows the total biovolume and total density of each Woahink Lake phytoplankton sample. Figure 24 shows the biovolume of each Woahink Lake phytoplankton sample by phylum.

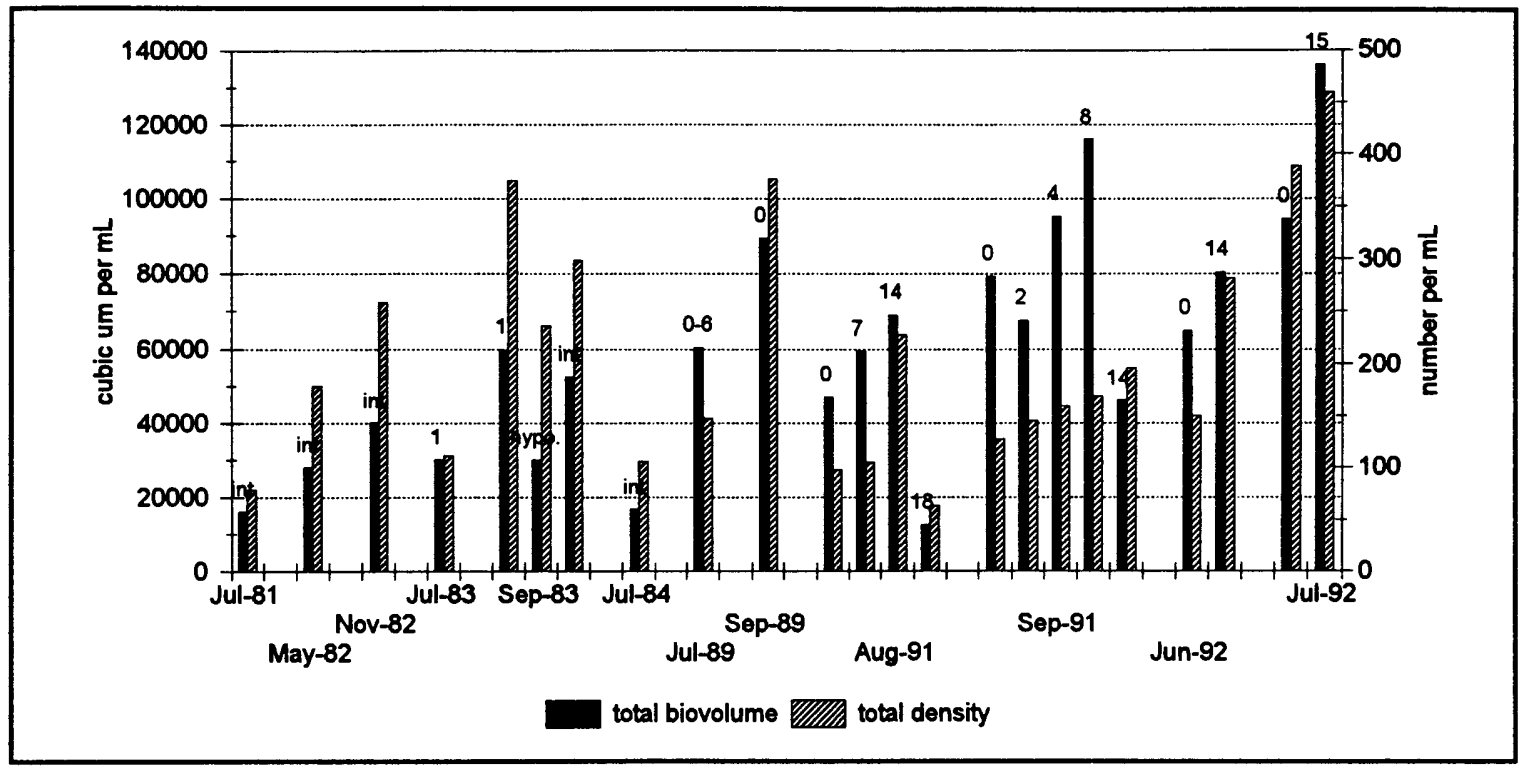

Figure 23. Total biovolume and total density for all phytoplankton samples collected at Woahink Lake since 1981. Sample depth above bar.

Although generally, in descending order of biovolume, samples have been composed of chrysophytes and cyanophytes, the 1991 samples were dominated by pyrrophytes and 


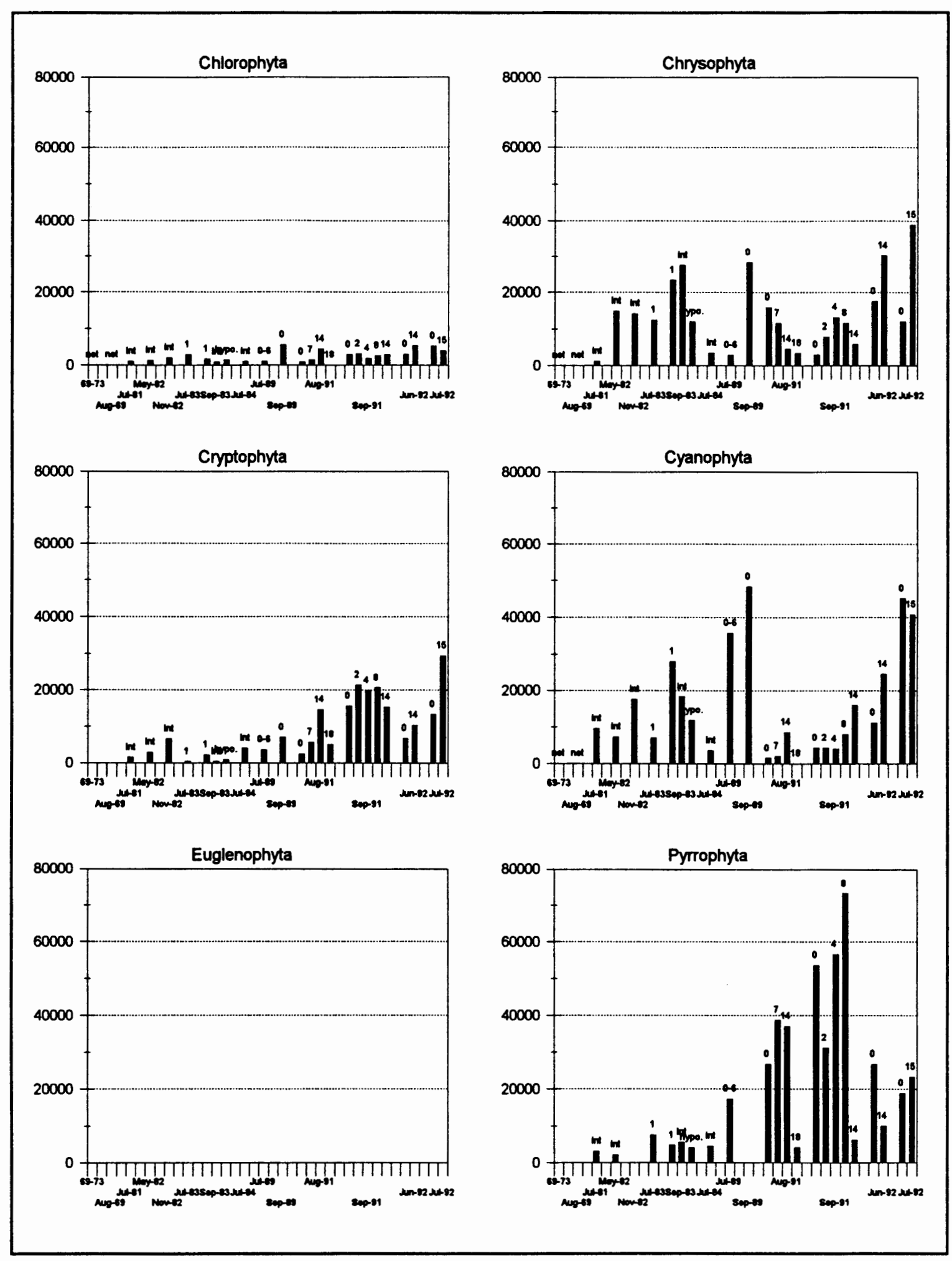

Figure 24. Biovolume of Woahink Lake phytoplankton by phylum. Units of $\mu \mathrm{m}^{3} \mathrm{~mL}^{-1}$. Sample depth above bar. 
cryptophytes. Chlorophytes have been a minor but constant percentage of sample biovolumes. Euglenophytes have not appeared in any of the samples.

The dominant chrysophytes have been Cyclotella stelligera and Coscinodiscus sp. The greatest biovolume of chrysophytes in any sample was $26200 \mu \mathrm{m}^{3} \mathrm{~mL}^{-1}$ of Coscinodiscus sp. from $14 \mathrm{~m}$ on June $24,1992$.

The dominant pyrrophytes have been Gymnodinium sp. and an unidentified dinoflagellate. The Gymnodinium sp. identification does not appear until the 1991 samples, when the unidentified dinoflagellate disappears, so they may be one and the same. The Gymnodinium sp. made up the greatest biovolume of a single species in any single sample, 73200 $\mu \mathrm{m}^{3} \mathrm{~mL}^{-1}$ in a sample collected september 4,1991 at $8 \mathrm{~m}$.

Anacystis marina has been the dominant cyanophyte and has been present in twenty-three of the twenty-five phytoplankton samples from the lake. The dominant cryptophyte has been Cryptomonas erosa. Generally, the most common chlorophyte based on biovolume has been Ankistrodesmus falcatus.

Figure 25 shows the distribution of trophic indicator species. The large majority of samples have contained only oligotrophic indicator species as large percentages of the total biovolume. The 1991 samples show lower percentages of oligotrophic indicator species, likely a result of the increases in pyrrophytes in those samples. The $15 \mathrm{~m}$ sample 


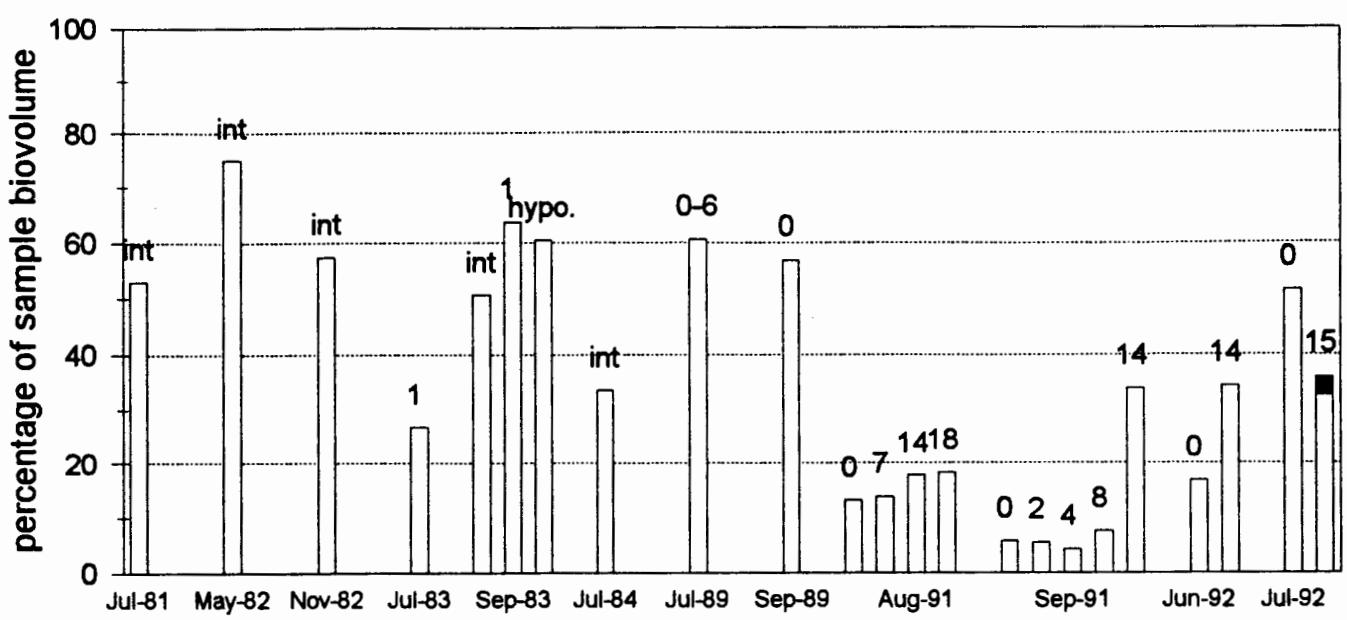

oligo

meso-eutro $\square$ eutro

Figure 25. Trophic indicator species in woahink Lake phytoplankton samples as a percentage of total sample biovolume. Sample depth above bar.

from July 29, 1992 showed the only noticeable concentration of non-oligotrophic species: the cyanophyte Oscillatoria sp. represented $3 \%$ of total sample biovolume.

The diversity and evenness indices for Woahink Lake phytoplankton samples collected since 1981 are graphed in Figure 26. The most diverse sample was collected at $1 \mathrm{~m}$ in July 1983.

Using the similarity index, a comparison was made between all of the depth integrated and surface samples. The values ranged from 17 to 65 . The greatest similarities were between samples collected in May 1982 and september 1983, index value of 65, and september 1982 and september 1983, value of 65 , also. Samples collected at the surface 


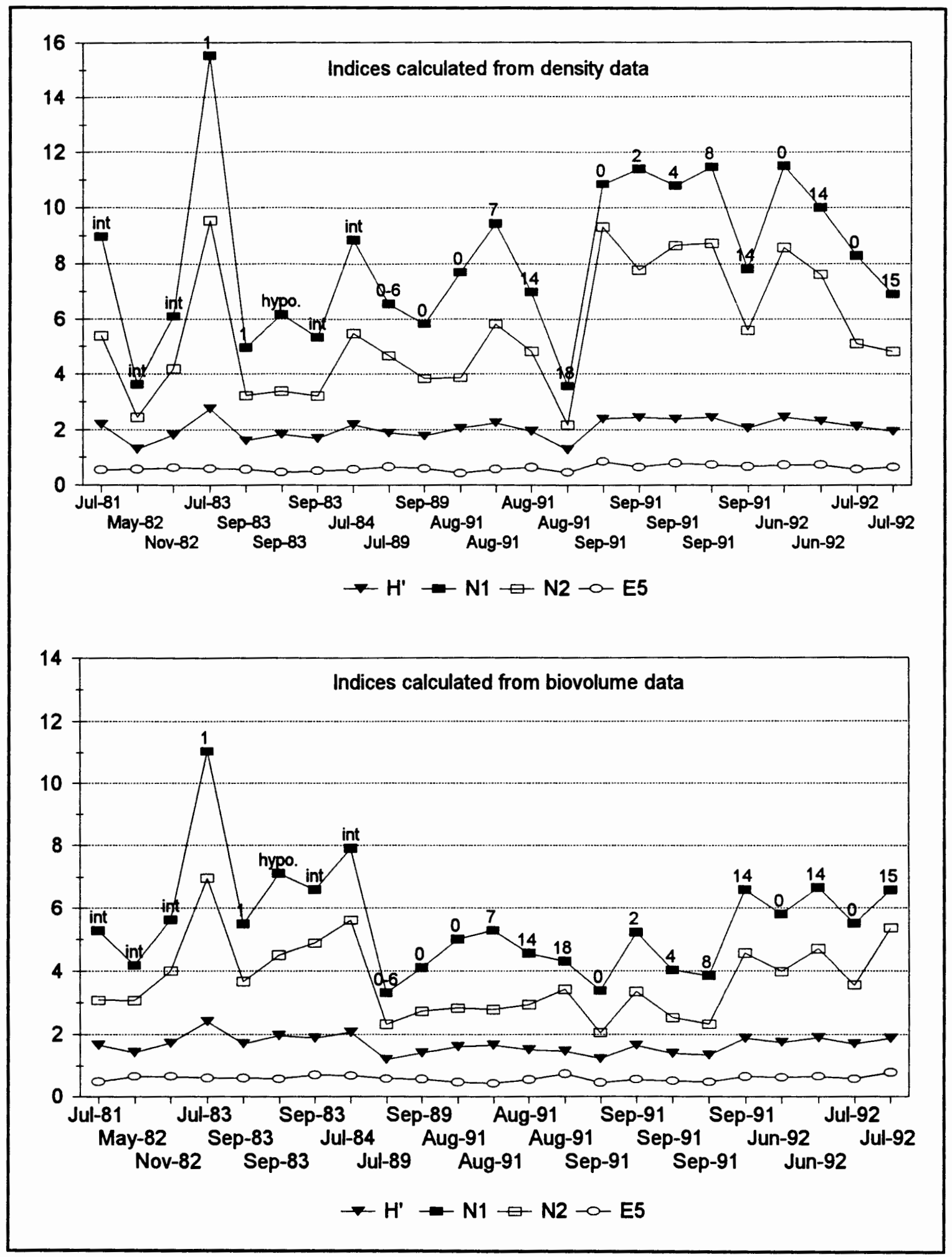

Figure 26. Diversity and evenness indices based on density and biovolume for Woahink Lake phytoplankton samples. Depth above top series. 
on July 28, 1983 and July 29, 1992 gave an index value of 45 .

As discussed previously, one of the curiosities in the data set from Woahink Lake has been the significant increase in Secchi Disk transparency since 1990. One possible explanation for this transparency increase would be a change in particle size and density. Increases in light transmission relative to secchi transparencies are often related to decreased scattering by suspended particles (Wetzel 1983). The attenuation of light may also be more closely related to particle surface area than to volume (Edmondson 1980). I interpret this to mean that given two particles of equal volume, the particle with greater surface area will attenuate more light. Assuming that organic particles, ie. phytoplankton, were responsible for the transparency increase, one hypothesis would be that larger phytoplankton at lower densities had replaced smaller phytoplankton at higher densities with the consequence that the larger phytoplankton attenuated less light. The evidence for this hypothesis is presented next.

Since 1981, there has been an apparent increase in the total phytoplankton sample biovolumes for surface and integrated samples collected during the summer. Phytoplankton densities for the same dates appear to be consistent until July of 1992 when the density doubles. These values are tabulated in Table IX. Figure 27 shows 
species biovolume versus cell size for selected dates to demonstrate that the sample biovolumes have been increasingly dominated by species with larger cell sizes. The exception, not graphed, occurred in July 1992 when the sample biovolume was dominated by a small spherical

cyanophyte, Anacystis marina. The trend in biovolume versus

TABLE IX

COMPARISON OF WOAHINK LAKE PHYTOPLANKTON BIOVOLUME AND DENSITY DATA FOR SELECTED DATES AND DEPTHS

\begin{tabular}{||c|c|c|c|}
\hline Date & Depth & $\begin{array}{c}\text { Biovolume } \\
\left(\mu \mathrm{m}^{3} \mathrm{~mL}^{-1}\right)\end{array}$ & $\begin{array}{c}\text { Density } \\
\left(\text { no. } \mathrm{mL}^{-1}\right)\end{array}$ \\
\hline $28-\mathrm{Jul}-1981$ & integrated & 16096 & 78 \\
\hline $28-\mathrm{Jul}-1983$ & $1 \mathrm{~m}$ & 30114 & 112 \\
\hline $13-\mathrm{Jul}-1984$ & integrated & 16695 & 106 \\
\hline $07-\mathrm{Jul}-1989$ & $0-6 \mathrm{~m}$ & 60443 & 148 \\
\hline $05-\mathrm{Aug}-1991$ & $0 \mathrm{~m}$ & 47178 & 98 \\
\hline $24-\mathrm{Jun}-1992$ & $0 \mathrm{~m}$ & 64972 & 150 \\
\hline $29-\mathrm{Jul}-1992$ & $0 \mathrm{~m}$ & 94572 & 389 \\
\hline
\end{tabular}

cell size would tend to support the hypothesis. The apparent constant density and increasing biovolume contradict the hypothesis.

However, the hypothesis may still be plausible if phytoplankton surface area to volume ratios have decreased and the phytoplankton therefore attenuated less light. Based on biovolume, the 1991 and 1992 samples showed an increase in the pyrrophyte Gymnodinium sp., a large oval 

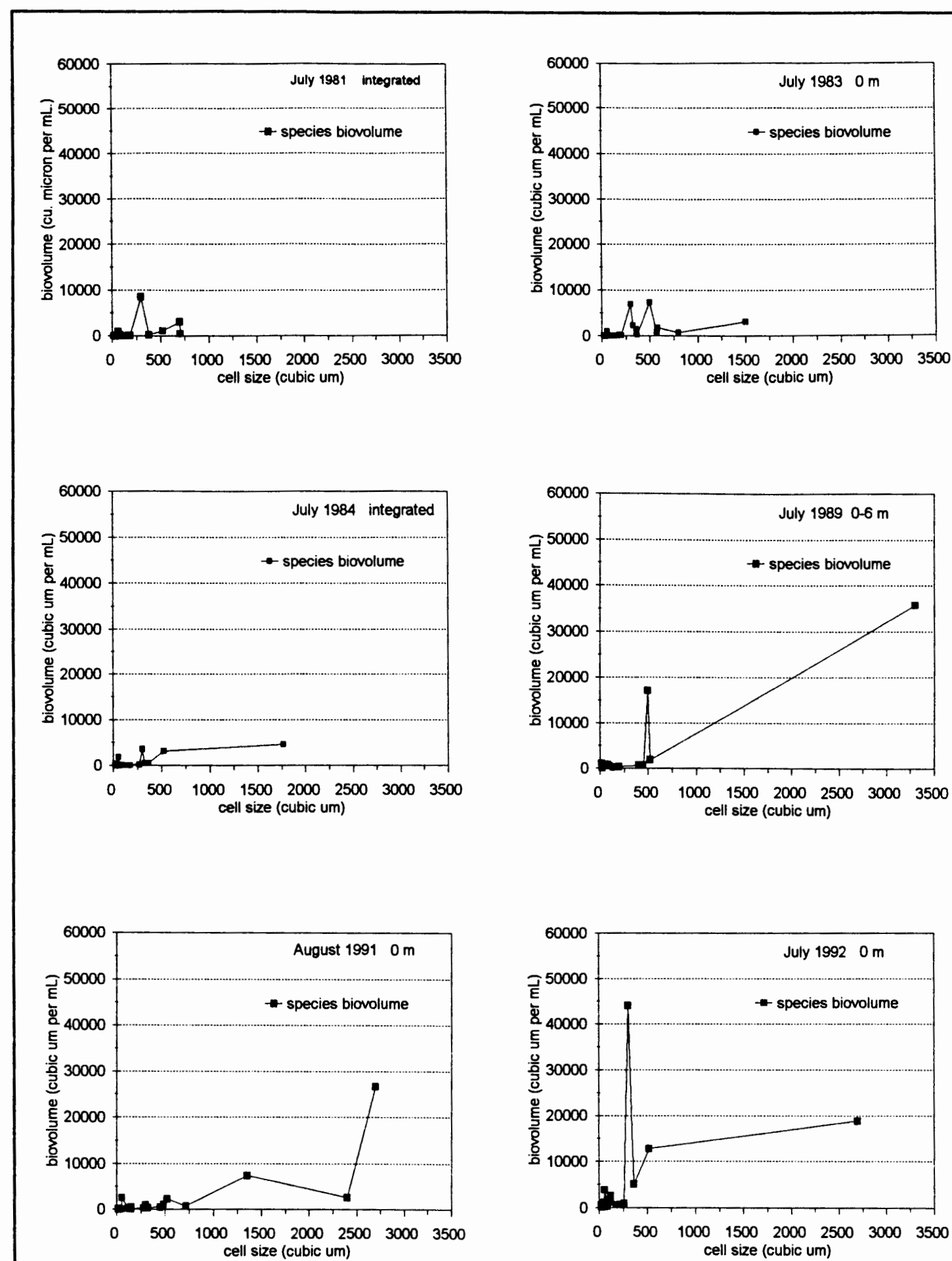

Figure 27. Total biovolume by species versus cell size for selected dates and depths at Woahink Lake. 
cell of approximately $2700 \mu \mathrm{m}^{3}$. This large oval cell has a small surface area to volume ratio and would attenuate less light. Therefore, it is possible that the increase in Secchi disk transparencies may be the result of changes in the phytoplankton community, specifically, the increase in Gymnodinium sp. As discussed previously, this dinoflagellate may have been identified as an unidentified dinoflagellate prior to 1991.

\section{ZOOPLANKTON}

Chapman and Fortune (1963) obtained the earliest zooplankton data for the study lakes. They investigated the zooplankton communities in Munsel and Woahink Lakes as part of a study on kokanee salmon ecology. At Mercer Lake, Robert McHugh (1972 unpublished) made brief remarks about the zooplankton present in phytoplankton samples and Kavanagh (1973) measured zooplankton biomass. Claska (1985) made a more intensive study of oregon lake zooplankton for samples collected during 1981. At Woahink Lake, the most systematic study was undertaken by Malick (1971) who conducted a year-long study of five species of zooplankton. The results of all zooplankton analyses except Malick's are compiled in Appendix F.

The results from samples collected by Larson and Salinas (1991 unpublished) are a significant addition to the information about the zooplankton communities in the study 
lakes. The data are summarized in Table $x$. These analyses provide the most detailed data on density and species composition, to date, and represent the first attempt to quantify the entire zooplankton community in each lake. The rotifer data are completely new information. Other than the rotifers, additions to the species lists compiled by claska (1985) are primarily benthic or rare zooplankters (Vogel personal communication).

over time, changes in the species identified may reflect changes in species composition or differences in taxonomy. To date, three or four different taxonomists have analyzed zooplankton samples at each lake. Clarifications of the taxonomy are presented in the discussion of each lake's zooplankton.

The most interesting story in the zooplankton of these lakes is the confirmed presence of a predatory zooplankter, Neomysis mercedis, in Munsel and Woahink Lakes. N. mercedis is an opossum shrimp of the order Mysidacea. Most likely, it is also present in Mercer Lake since mysids have been identified there previously. These shrimp are often underrepresented in zooplankton tows because they are primarily benthic dwellers, typically migrating vertically only at night to hunt.

Opossum shrimp from these lakes have been variously identified as mysids, Mysis, Mysis relicta, and, most recently, as Neomysis mercedis. The term mysid refers to 
TABLE X

SUMMARY OF ZOOPLANKTON DATA FOR SAMPLES COLLECTED
IN 1991 AT THE STUDY LAKES

\begin{tabular}{|c|c|c|c|c|c|}
\hline Lake & Date & stn & $z(m)$ & $\begin{array}{c}\text { Total } \\
\text { density } \\
\left(\mathrm{m}^{-3}\right)\end{array}$ & $\begin{array}{l}\text { Dominant sp. } \\
\text { (Dom. class or } \\
\text { order) }\end{array}$ \\
\hline \multirow[t]{3}{*}{ Mercer } & 08-Aug-91 & 1 & $9-0$ & 247327 & $\begin{array}{l}\text { Kellicottia bostonensis } \\
\text { (Rotifera) }\end{array}$ \\
\hline & & 2 & $9-0$ & 352870 & K. bostonensis (Rotifera) \\
\hline & 13-Sep-91 & 1 & $10-0$ & 148185 & $\begin{array}{l}\text { Plocsoma truncatum } \\
\text { (Rotifera) }\end{array}$ \\
\hline \multirow[t]{7}{*}{ Munsel } & 09-Aug-91 & 1 & $8-0$ & 22537 & $\begin{array}{l}\text { Diaphanosoma brachyurum } \\
\text { (Cladocera) }\end{array}$ \\
\hline & & 1 & $16-0$ & 30947 & D. brachyurum (Cladocera) \\
\hline & & 2 & $8-0$ & 22686 & D. brachyurum (Cladocera) \\
\hline & 13-Sep-91 & 1 & $7-0$ & 50492 & D. brachyurum (Copepoda) \\
\hline & & 1 & $14-0$ & 50330 & D. brachyurum (Copepoda) \\
\hline & & 2 & $7-0$ & 48451 & $\begin{array}{l}\text { Diaptomus novamexicanus } \\
\text { (Copepoda) }\end{array}$ \\
\hline & & 2 & $11-0$ & 59310 & D. brachyurum (Copepoda) \\
\hline \multirow[t]{8}{*}{ Woahink } & 05-Aug-91 & 3 & $7-0$ & 43369 & D. brachyurum (Cladocera) \\
\hline & & 3 & $14-0$ & 37313 & D. brachyurum (Cladocera) \\
\hline & & 4 & $7-0$ & 70309 & D. brachyurum (Cladocera) \\
\hline & & 4 & $14-0$ & 37382 & D. brachyurum (Cladocera) \\
\hline & 04-Sep-91 & 3 & $7-0$ & 20049 & Cyclops vernalis (Copepoda) \\
\hline & & 3 & $14-0$ & 17752 & Cyclops vernalis (Copepoda) \\
\hline & & 4 & $7-0$ & 36477 & Cyclops vermalis (Copepoda) \\
\hline & & 4 & $14-0$ & 31604 & Cyclops vernalis (Copepoda) \\
\hline
\end{tabular}

the order, Mysidacea. The terms Mysis and Mysis relicta both refer to the species, Mysis relicta. M. relicta is reported in lakes east of the Great Plains and in Canada, 
the Great Lakes, and brackish east coast estuaries. Neomysis mercedis occurs in lakes, rivers, and brackish estuaries on the west coast (Pennak 1989). In a Woahink Lake benthic sample, it is likely that the shrimp identified as Mysis, are also Neomyis mercedis.

While Neomysis relicta occurs naturally on the west coast, there is a question as to whether they are a native or an introduced species in the study lakes. Yeoman and Griffiths (1938) noted the presence of mysids only in the stomachs of fish collected in Eel and Tenmile Lakes. Mysids were found in fish stomachs at Mercer, Munsel, and Woahink Lakes by Oakley $(1962 a, b)$ and Saltzman (1962), respectively. Saltzman (1962) mentioned unconfirmed reports that stocking of "shrimp" had occurred at two locations on Woahink Lake in 1942. The Oregon Department of Fish and Wildlife apparently stocked only eleven cascade lakes with Mysis between 1965 and 1967 (Weatherbee 1990).

Pennak (1989) reports that introductions of Mysis have caused "drastic decreases in densities of Daphnia and Bosmina, as well as shifts in density ratios of other cladoceran zooplankters." Since Neomysis mercedis fills the same ecological niche as Mysis, it can be assumed that $N$. mercedis would have a similar impact on other zooplankton populations.

Mercer Lake Zooplankton

Zooplankton have been collected at Mercer Lake since 
1972 (see Table II), however, the first detailed survey did not occur until 1981 (Claska 1988). All species identified in 1991 were also identified by Claska (1988) with the exceptions of the copepod orthocyclops modestus, the cladocera Leptodora kindti, and the rotifers.

In 1991, vertical zooplankton tows were made on two dates (see Table $\mathrm{X}$ ). The total densities were, by far, the highest densities reported at any of the three lakes. In order of descending density, all three samples were composed of rotifers, copepods, and cladocerans. In August, rotifers comprised approximately $80 \%$ of the total density. In September, the total zooplankton density had decreased. Rotifers still dominated, although their numbers had decreased, and copepod numbers had increased. The presence of Leptodora kindti and Chaoborus larvae, and the large numbers of rotifers indicate that the crustacean zooplankton population (Cladocera and Copepoda) was controlled by invertebrate predation (Vogel personal communication).

\section{Munsel Lake Zooplankton}

Chapman and Fortune (1962) completed the first investigation of zooplankton in Munsel Lake. Other researchers who have collected zooplankton at Munsel Lake are listed in Table II.

The only species identified by Claska (1988) and not present in the 1991 samples was the cladoceran Diaphanosoma brachyurum. New additions to Claska's species list are the 
rotifers, the benthic Harpacticoid Copepoda, and the opossum shrimp Neomysis mercedis. Chapman and Fortune (1962) identified a daphnid as Daphnia longispina. This species does not occur in North America and is likely Daphnia galeata (Vogel personal communication, Brooks 1957). Daphnia galeata was present in the samples from 1991 and in the samples collected in the 1980's.

In 1991, vertical zooplankton tows were made by Larson and Salinas (1991 unpublished) on two dates (see Table X). The total densities were higher in September than August. Densities of both cladocerans and copepods were higher in September. In August, Cladocerans dominated the samples and, in september, Copepods dominated the samples. In all of the samples, rotifers made up less than $6 \%$ of the total density. On both dates, greater than $70 \%$ of the zooplankton were present above $8 \mathrm{~m}$.

The Munsel Lake rotifer population may have been suppressed by interference competition (Vogel personal communication). It has been demonstrated that large daphnids, such as Daphnia galeata mendotae, present at densities $\geq 1-5$ liter $^{-1}$ have caused the decline of rotifer populations through mechanical interference (Burns and Gilbert 1986, Gilbert 1988, Schneider 1990). Daphnia galeata mendotae is present in all of the 1991 samples at densities $>3$ liter ${ }^{-1}$. According to Vogel (personal communication), "[t]he susceptible rotifer species, Ploesoma 
truncatum, nearly disappeared between August and september.... The surviving rotifers were either heavily armored (Kellicottia longispina) or able to avoid being digested (Polyarthra sp.). The Keratella morph present in September was more robust than the August form, hence also had an improved chance of survival." Gilbert (1980) suggests that large daphnids may also suppress rotifer populations through exploitative competition while schneider (1990) attributes the suppression of rotifer populations only to mechanical interference.

\section{Woahink Lake Zooplankton}

Chapman and Fortune (1962) completed the first investigation of Woahink zooplankton. Other researchers who have collected zooplankton at Woahink Lake are listed in Table II.

There are a number of conflicts between the 1991 species lists and those compiled by Chapman and Fortune (1962), Malick (1971), and Claska (1988). The species in question are Daphnia Iongispina, Cyclops bicuspidatus thomasi, Diaptomus franciscanus, Diaptomus kenai, and Eubosmina hagmanni.

Chapman and Fortune (1962) and Malick (1971) identified a daphnid as Daphnia longispina. As mentioned previously, Daphnia longispina does not occur in North America (Vogel personal communication, Brooks 1957) so this daphnid is likely Daphnia galeata mendotae, which occurs in Mercer and 
Munsel Lakes, or Daphnia rosea, which is common in oregon (Claska 1988). The fact that no daphnids have been observed in Woahink Lake since 1981 is discussed later in this section.

Malick (1971) identified Cyclops bicuspidatus thomasi during all months except February. Cyclops bicuspidatus thomasi and Cyclops vernalis often replace one another seasonally, $C$. thomasi being the cooler water species and $C$. vernalis being the warmer water species (Vogel personal communication). Cyclops vernalis was identified in the 1991 samples and by claska (1988).

Malick (1971) also identified Diaptomus franciscanus in every sample he collected at Woahink Lake. This species was not identified by claska (1988) in any mid-coast lakes and was not present in the 1991 samples. The zooplankter may be Diaptomus hesperus which was identified in small numbers in the 1991 samples and is found at low elevations close to salt water (Vogel personal communication) . surprisingly, Claska (1988) did not find $D$. hesperus in Woahink although she found it in only nine coastal lakes between Florence and North Bend. This discrepancy is discussed next.

There are some apparent contradictions between charts and text presented by claska (1988). In the species list for Woahink Lake, Diaptomus kenai and Eubosmina hagmanni are both listed as present. However, the text states that Diaptomus kenai was found only in Cascade lakes and that 
Eubosmina hagmanni was found only at elevations above 1200 m. The diaptomid may be Diaptomus hesperus since it was found in nine nearby lakes (Claska 1988). The bosmina may be Bosmina longirostris since it was also identified by Claska (1988) in Woahink and in nearby lakes. Claska (1988) also stated that Eubosmina hagmanni and Bosmina longirostris never co-occurred in the study.

Malick (1971) counted five species of zooplankton monthly from July 1968 through August 1969. Total densities ranged from a low of $600 \mathrm{~m}^{-3}$ during the winter to $8200 \mathrm{~m}^{-3}$ in October.

In 1991, zooplankton tows were made by Larson and Salinas (1991 unpublished) on two dates (see Table X). Total densities were always higher in the 7-0 $\mathrm{m}$ tows than in the 14-0 m tows, indicating that below $7 \mathrm{~m}$ the mesh of the zooplankton net was becoming clogged with material other than zooplankton. As discussed previously in the phytoplankton section, large biovolumes of dinoflagellates were present in the water column on the sampling dates. It is possible that these large phytoplankton clogged the net during the 14-7 $\mathrm{m}$ section of the tows. In August, all samples were composed of approximately $70 \%$ cladocerans, $15 \%$ copepods, and $15 \%$ rotifers. In september, total densities were lower than those of August and samples were composed of 10\% cladocerans, $85 \%$ copepods, and 5\% rotifers.

Malick's (1971) year-long collection effort in 1968- 
1969 provides an opportunity for comparison with the 1991 samples. All species, except for those counted by Malick, were deleted from the 1991 counts for station 3 (7-0 m) and the densities were totaled again. The highest density reported by Malick was $8200 \mathrm{~m}^{-3}$. The re-totaled 1991 densities were $31952 \mathrm{~m}^{-3}$ in August and $15286 \mathrm{~m}^{-3}$ in September. The lowest 1991 value was twice as large as Malick's highest value.

The most interesting occurrences in the 1991 zooplankton samples were the continued absence of any daphnids since at least 1981, the apparent suppression of the september rotifer population by Cyclops vernalis, and the lower than predicted number of pelagic crustacean species (Vogel personal communication). These topics are addressed next.

Daphnids have apparently become extinct in woahink Lake, possibly as a result of predation by Neomysis mercedis (Vogel personal communication). Chapman and Fortune (1962) and Malick (1971) both identified a daphnid during their sampling. Claska (1988) did not identify any daphnids and none were present in the 1991 samples. Neomysis mercedis was captured in a zooplankton tow in september 1991 and was also the most prevalent organism in a benthic sample collected in August 1991.

N. mercedis is a voracious predator on crustacean zooplankton populations. As discussed in the introduction 
to the zooplankton results section, Mysis introductions have altered cladoceran density ratios and caused dramatic decreases in densities of Daphnia and Bosmina (Pennak 1989). Several researchers suggested that the disappearance from Lake Tahoe of two species of Daphnia and Bosmina longirostris was partially caused by predation by Mysis relicta (Threlkeld 1979, Cooper and Goldman 1980). Threlkeld (1981) reported that recolonization of lake Tahoe by $B$. longirostris was accompanied by reduced populations of M. relicta, and that these $M$. relicta population reductions were partly responsible for the reappearance of $B$. longirostris. Bosmina longirostris was identified in all three lakes by claska (1988) and was also present in all three lakes in 1991. Threlkeld (1981) noted that there was an inverse relationship between densities of $B$. longirostris and Epischura nevadensis; this relationship did not occur in the 1991 Woahink Lake samples.

Murtaugh (1981) reported that $N$. mercedis consistently preferred Daphnia as prey and that a large population of $N$. mercedis may have excluded Daphnia from Lake Washington. Murtaugh (1981) noted that other zooplankter abundances did not change when the Daphnia and $N$. mercedis interactions occurred.

These studies support the hypothesis that Neomysis mercedis has caused the disappearance of Daphnia from Woahink Lake. 
Neomysis mercedis may also be responsible for the lower than predicted number of pelagic crustacean zooplankton species in Woahink Lake (Vogel personal communication). In analyzing the 1991 zooplankton counts, Vogel applied Dodson's (1992) model which predicts crustacean species richness based on lake surface area, primary productivity, and the number of lakes within $20 \mathrm{kilometers.} \mathrm{The} \mathrm{model}$ predicted 10 species of crustaceans and only 6 were counted (Vogel personal communication). While Murtaugh (1981) suggested that Daphnia may be the preferred prey of $N$. mercedis, Pennak (1989) reported that the prey order of preference for Mysis is cladocerans > copepod copepodites > copepod nauplii > adult copepods (Pennak 1989).

September 1991 rotifer populations in Woahink Lake may have been suppressed by predation by Cyclops vernalis (Vogel personal communication). August and september densities of rotifers and cyclops vernalis were apparently inversely related. Decreased rotifer numbers during september were accompanied by increased densities of cyclops vernalis.

\section{BENTHIC INVERTEBRATES}

As listed in Table II, benthic samples have been collected from the study lakes since 1938. The results of the analyses of all benthic samples are presented in Appendix G. Unfortunately, Griffiths and Yeoman (1938) 
combined all of the benthic data from their 10 lakes, so their results reflect the composite species list and percent composition. Therefore, it is very difficult to compare those data to any data collected more recently. (Note that in Appendix G, each lake's benthic invertebrate data include Griffith and Yeoman's composite invertebrate percentages.)

In general, all benthic samples from the study lakes contain organisms typically found in lake sediments. There is no glaring absence or presence of any organisms and the general lack of species diversity is possible an artifact of the sampling protocols and taxonomic methods (Rick Hafele personal communication).

The 1991 samples were less diverse than those collected previously and contained fewer insects. This was possibly the result of reduced oxygen conditions at the sample depths. A number of the organisms collected by all researchers are able to tolerate low concentrations of dissolved oxygen including aquatic oligochaetes, cladocerans, ostracods, Bryozoa statoblasts, and gastropods (Pennak 1989).

It is difficult to draw any conclusions about eutrophication based on the benthic invertebrate data because of the inconsistent sampling protocols, inconsistent sampling seasons, distribution of organisms on various substrates, and the small number of samples. 
The most interesting result from the 1991 data is the presence of opossum shrimp in the Woahink Lake sample. As noted previously, Neomysis mercedis was identified in the 1991 zooplankton samples collected at Munsel Lake and Woahink Lake.

\section{Mercer Lake Benthic Invertebrates}

Griffiths and Yeoman (1938) ranked Mercer Lake as the most productive of their 10 study lakes based on the weight of benthic organisms per unit area.

Oakley (1962a) reported that at Mercer Lake, mysids were not collected in benthic samples, but they were the dominant organism in the fish stomachs that were analyzed. Based on the biological and chemical evidence gathered during their study of 17 lakes, Oakley (1962a) rated Mercer Lake's productivity as higher than average.

The benthic sample collected by Larson and Salinas (1991 unpublished) were dominated by Bryozoans, Chaoborus larvae and pupa, and Daphnia. In the zooplankton tows for the same date, Daphnia were the second most prevalent zooplankter after rotifers.

\section{Munsel Lake Benthic Invertebrates}

Based on the weight of benthic organisms, Griffiths and Yeoman ranked Munsel as the second most productive lake of the 10 they sampled. 
Oakley (1962b) reported that the dominant invertebrates collected were chironomids, oligochaetes, and gastropods. Mysids were present in fish stomachs but were not collected in benthic samples. Oakley rated Munsel Lake's productivity as low, based on their study of 17 lakes.

The benthic samples collected by Larson and Salinas (1991 unpublished) were dominated by oligochaetes, chironomids, and pelecypods. There were few insects in these samples and this is probably a result of anoxic conditions in the lower hypolimnion. Mysids were collected in zooplankton tows but were not present in the benthic samples.

\section{Woahink Lake Benthic Invertebrates}

Based on the weight of benthic organisms per unit area, Griffiths and Yeoman listed Woahink Lake as the least productive of their ten study lakes.

Saltzman (1962) reported that benthic samples collected in 1947 were dominated by Chironomus larvae and amphipods. Mysids were found in fish stomachs but were not collected in benthic samples.

MCGie and Breuser (1962) reported that benthic samples were dominated by amphipods, Ephemeridae larvae, and oligochaetes. A single mysid was also found in sediment samples, and several more were present in fish stomachs. The benthic sample collected by Larson and Salinas (1991 unpublished) was dominated by mysids (36\%), 
chironomids and pelecypods. As discussed previously, the mysid shrimp identified as Mysis is likely Neomysis mercedis. 
SUMMARY AND DISCUSSION

CURRENT TROPHIC STATUS

The estimates of the current trophic states of the study lakes are based on comparison of data from 1991 and 1992 with tables of values compiled by wetzel (1983) and Sweet (1986). Table XI lists the mean and, in some cases,

TABLE XI

TROPHIC STATE CATEGORIES AND WATER QUALITY PARAMETERS

\begin{tabular}{|c|c|c|c|}
\hline Parameter & oligotrophic & Mesotrophic & Eutrophic \\
\hline $\begin{array}{l}\text { primary } \\
\text { productivity } \\
\left.\text { (mg C m } \mathrm{m}^{-2} \mathrm{~d}^{-1}\right)\end{array}$ & $50-300$ & $250-1000$ & $>1000$ \\
\hline $\begin{array}{l}\text { chlorophyll a } \\
(\mu \mathrm{g} / \mathrm{L})\end{array}$ & $\begin{array}{c}1.7 \\
.3-4.5 \\
\end{array}$ & $\begin{array}{c}4.7 \\
3-11 \\
\end{array}$ & $\begin{array}{l}14.3 \\
3-78 \\
\end{array}$ \\
\hline $\begin{array}{l}\text { phytoplankton } \\
\text { biovolume (1) } \\
\left(\mu \mathrm{m}^{-3} \mathrm{~mL}^{-1}\right)\end{array}$ & 105000 & 329000 & 1056000 \\
\hline $\begin{array}{l}\text { phytoplankton } \\
\text { density (1) } \\
\text { (no./mL) }\end{array}$ & 228 & 656 & 1066 \\
\hline $\begin{array}{l}\text { total } \\
\text { phosphorus } \\
\text { (mg/I) }\end{array}$ & $\begin{array}{c}.008 \\
.003-.0177\end{array}$ & $\begin{array}{c}.0267 \\
.0109-.0956\end{array}$ & $\begin{array}{c}.0844 \\
.016-.386\end{array}$ \\
\hline $\begin{array}{l}\text { extinction } \\
\text { coefficient } \\
\left(\mathrm{m}^{-1}\right) \\
\end{array}$ & $.05-1.0$ & $.1-2.0$ & $.5-4.0$ \\
\hline $\begin{array}{l}\text { Secchi depth } \\
\text { (m) }\end{array}$ & $\begin{array}{c}9.9 \\
5.4-28.3 \\
\end{array}$ & $\begin{array}{c}4 \cdot 2 \\
1 \cdot 5-8 \cdot 1 \\
\end{array}$ & $\begin{array}{l}2.45 \\
.8-7.0 \\
\end{array}$ \\
\hline $\begin{array}{l}\text { dissolved } \\
\text { oxygen profile }\end{array}$ & orthograde & & clinograde \\
\hline
\end{tabular}

Note: (1) Sweet 1986; all others from Wetzel (1983) 
the range for trophic state variables. Table XII lists the values for the variables based on the 1991 and 1992 data.

TABLE XII

TROPHIC STATE INDICATORS FOR STUDY LAKES:

MEAN AND RANGE OF SELECTED VARIABLES

\begin{tabular}{|c|c|c|c|}
\hline Parameter & Mercer Lake & Munsel Lake & Woahink Lake \\
\hline $\begin{array}{l}1991 \\
\text { approximate } \\
\text { daily primary } \\
\text { productivity } \\
\left.\text { (mg } \mathrm{Cm}^{-2} \mathrm{~d}^{-1}\right)\end{array}$ & $\begin{array}{c}1460 \\
\text { (eutrophic) }\end{array}$ & $\begin{array}{c}729 \\
635-823 \\
\text { (mesotrophic) }\end{array}$ & $\begin{array}{c}590 \\
488-692 \\
\text { (mesotrophic) }\end{array}$ \\
\hline $\begin{array}{l}1991 \\
\text { chlorophyl1 a } \\
(\mu g / L)\end{array}$ & $\begin{array}{c}17.4 \\
11.5-16.3 \\
\text { (eutrophic) }\end{array}$ & $\begin{array}{l}3.0 \\
0.8-6.5 \\
\text { (oligotrophic- } \\
\text { mesotrophic) }\end{array}$ & NA \\
\hline $\begin{array}{l}1992 \\
\text { chlorophyll a } \\
(\mu \mathrm{g} / \mathrm{L})\end{array}$ & $\begin{array}{c}10.1 \\
4.3-17.5 \\
\text { (mesotrophic- } \\
\text { eutrophic) }\end{array}$ & $\begin{array}{c}3.5 \\
1.4-6.7 \\
\text { (oligotrophic- } \\
\text { mesotrophic) }\end{array}$ & $\begin{array}{c}1.9 \\
1.2-2.7 \\
\text { (oligotrophic) }\end{array}$ \\
\hline $\begin{array}{l}1991 \\
\text { phytoplankton } \\
\text { biovolume (1) } \\
\left(\mu \mathrm{m}^{-3} \mathrm{~mL}^{-1}\right)\end{array}$ & $\begin{array}{l}180947 \\
\text { 148746-208953 } \\
\text { (oligotrophic- } \\
\text { mesotrophic) }\end{array}$ & $\begin{array}{c}97502 \\
20017-222470 \\
\text { (oligotrophic) }\end{array}$ & $\begin{array}{c}65803 \\
12494-116022 \\
\text { (oligotrophic) }\end{array}$ \\
\hline $\begin{array}{l}1992 \\
\text { phytoplankton } \\
\text { biovolume (1) } \\
\left(\mu \mathrm{m}^{-3} \mathrm{~mL}^{-1}\right)\end{array}$ & $\begin{array}{c}345244 \\
276378-460526 \\
\text { (mesotrophic) }\end{array}$ & $\begin{array}{c}108403 \\
16352-439861 \\
\text { (oligotrophic) }\end{array}$ & $\begin{array}{c}93994 \\
64973-136085 \\
\text { (oligotrophic) }\end{array}$ \\
\hline $\begin{array}{l}1991 \\
\text { phytoplankton } \\
\text { density (1) } \\
\text { (no./mL) }\end{array}$ & $\begin{array}{c}272 \\
210-297 \\
\text { (oligotrophic) }\end{array}$ & $\begin{array}{c}288 \\
142-594 \\
\text { (oligotrophic) }\end{array}$ & $\begin{array}{c}144 \\
63-228 \\
\text { (oligotrophic) }\end{array}$ \\
\hline $\begin{array}{l}1992 \\
\text { phytoplankton } \\
\text { density (1) } \\
\text { (no./mL) }\end{array}$ & $\begin{array}{c}1622 \\
428-4566 \\
\text { (eutrophic) }\end{array}$ & $\begin{array}{c}309 \\
51-518 \\
\text { (oligotrophic) }\end{array}$ & $\begin{array}{c}320 \\
150-460 \\
\text { (oligotrophic) }\end{array}$ \\
\hline $\begin{array}{l}1992 \text { total } \\
\text { phosphorus } \\
\text { (mg/L) }\end{array}$ & $\begin{array}{c}.02 \\
\text { (mesotrophic) }\end{array}$ & $\begin{array}{c}<.01 \\
<.01-.01 \\
\text { (oligotrophic) }\end{array}$ & $\begin{array}{c}<.01 \\
\text { (oligotrophic) }\end{array}$ \\
\hline
\end{tabular}

Note: (1) Sweet 1986; all others from Wetzel (1983) 
TABLE XII

TROPHIC STATE INDICATORS FOR STUDY LAKES:

MEAN AND RANGE OF SELECTED VARIABLES

(continued)

\begin{tabular}{|c|c|c|c|}
\hline $\begin{array}{l}1992 \\
\text { extinction } \\
\text { coefficient } \\
\left(\mathrm{m}^{-1}\right)\end{array}$ & $\begin{array}{c}.57 \\
.50-.64 \\
\text { (oligotrophic- } \\
\text { mesotrophic) }\end{array}$ & $\begin{array}{c}.40 \\
.33-.46 \\
\text { (oligotrophic- } \\
\text { mesotrophic) }\end{array}$ & $\begin{array}{c}.28 \\
.27-.28 \\
\text { (oligotrophic) }\end{array}$ \\
\hline $\begin{array}{l}1991 \\
\text { Secchi depth } \\
\text { (m) }\end{array}$ & $\begin{array}{c}4.3 \\
2.8-5.7 \\
\text { (mesotrophic) }\end{array}$ & $\begin{array}{c}4.8 \\
4.5-5.4 \\
\text { (mesotrophic) }\end{array}$ & $\begin{array}{c}4.9 \\
3.6-6.6 \\
\text { (mesotrophic) }\end{array}$ \\
\hline $\begin{array}{l}1992 \\
\text { Secchi depth } \\
\text { (m) }\end{array}$ & $\begin{array}{c}4 \cdot 2 \\
3.3-5 \cdot 3 \\
\text { (mesotrophic) }\end{array}$ & $\begin{array}{l}5.7 \\
3.7-7.3 \\
\text { (oligotrophic- } \\
\text { mesotrophic) }\end{array}$ & $\begin{array}{l}5.4 \\
\quad 4.1-8.7 \\
\text { (oligotrophic- } \\
\text { mesotrophic) }\end{array}$ \\
\hline $\begin{array}{l}\text { dissolved } \\
\text { oxygen } \\
\text { profile }\end{array}$ & $\begin{array}{l}\text { clinograde } \\
\text { (eutrophic) }\end{array}$ & $\begin{array}{c}\text { clinograde } \\
\text { (eutrophic) }\end{array}$ & $\begin{array}{l}\text { clinograde } \\
\text { (mesotrophic) }\end{array}$ \\
\hline
\end{tabular}

Mercer Lake is currently mesotrophic to eutrophic but closer to mesotrophic. Munsel Lake is oligotrophic to mesotrophic but closer to oligotrophic. Woahink Lake is oligotrophic to mesotrophic but very close to oligotrophic.

\section{EVIDENCE FOR EUTROPHICATION}

In the research presented in this thesis, the most useful parameters for examining potential eutrophication are primary productivity, chlorophyll a concentration, nutrient concentrations, optical characteristics, and dissolved oxygen profiles. Additionally, in Woahink Lake, the zooplankton data for selected species can be examined 
historically. These preceding variables have been investigated over the longest period of time in the study lakes. The remaining data for phytoplankton, zooplankton, and benthic invertebrates are most useful as supporting evidence in determining the current trophic status of these lakes.

Although much limnological data was gathered from the lakes between 1938 and 1992, most of it is not adequate for assessing trends in lake water quality. The scattered and discontinuous database precludes statistical analyses of water quality trends. Conclusions about eutrophication are confined to speculations based on visual inspection of graphs and tables. Data for primary productivity and, in one case, for chlorophyll a suggest that the lakes have become more eutrophic. However, water quality parameters may vary greatly with season, depth, and climate, and the studies used here for comparison offer a patchwork of sampling dates, parameters, and protocols that make comparisons difficult. Comprehensive and long-term studies such as those completed by Larson (1970a), Kavanagh (1973), and Malick (1971) must be repeated periodically to monitor water quality changes over decades.

\section{Mercer Lake}

Data for primary productivity and chlorophyll a show evidence of increased biological productivity. The single 
$1991{ }^{14} \mathrm{C}$ primary productivity value of $146 \mathrm{mg} \mathrm{C} \mathrm{m}^{-2} \mathrm{hr}^{-1}$ is 1.7 times higher than the highest of 13 values recorded from 1970 to 1972. Concentrations of chlorophyll a for 1991 and 1992 are two to five times higher than values for similar dates in 1971, with the exception of values measured in late June 1971 which were the highest ever measured in the lake. Data for nutrient concentrations, optical characteristics, and dissolved oxygen show no obvious pattern of eutrophication. The $1992\left[\mathrm{P}_{\mathrm{T}}\right]$ concentrations are two to five times larger than $\left[P_{T}\right]$ measured in 1971, but less than the mean of $.035 \mathrm{mg} / \mathrm{L}$ for summer surface concentrations. Historic Secchi depth data are sporadic; however, measurements made from 1991 to 1993 are comparable with past measurements and the greatest secchi depth was measured in 1991. Extinction coefficients calculated for 1992 data fall above and below the value calculated for 1971 data. Dissolved oxygen profiles collected from 1938 to the present are very similar; each year hypolimnetic anoxia occurred soon after stratification and strong reducing conditions developed by mid-summer. Data suggest that, historically, nutrients have been recycled from the sediment.

The primary productivity measurements and chlorophyll a data suggest that productivity has increased in Mercer Lake. The entire data set shows that extremely productive conditions have existed in Mercer Lake since 1938. 
Munsel Lake

Primary productivity data suggest that Munsel Lake has undergone eutrophication. The two 1991 primary productivity

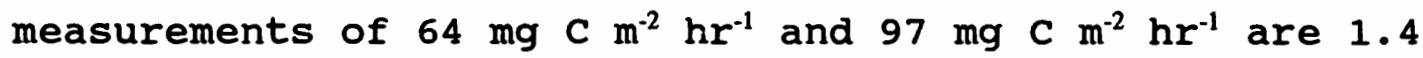
and 2.2 times higher, respectively, than the maximum value measured from 1970 to 1972 .

Data collected in 1991 and 1992 for chlorophyll a, total phosphorus, optical characteristics, and dissolved oxygen are similar to historically collected data. on comparable dates, 1971 chlorophyll a data are similar to, and slightly higher than, 1991 and 1992 data. The 1992 [ $\mathrm{P}_{\mathrm{T}}$ ] values of $.01 \mathrm{mg} / \mathrm{L}$ and $<.01 \mathrm{mg} / \mathrm{L}$ are higher than summer values measured by Kavanagh (1973) but are lower than the mean of $.023 \mathrm{mg} / \mathrm{L}$ for all summer surface samples. Maximum and mean Secchi Disk depths for 1992 and 1993 are greater than values recorded from 1967 to 1968 and similar to measurements made from 1978 to 1979. Extinction coefficients calculated for 1992 data are larger and smaller than the extinction coefficient calculated by Kavanagh (1971). Dissolved oxygen data collected in 1991 and 1992 are very similar to data collected since 1938. The 1991 data confirm that, since 1938 , strong reducing conditions have existed at the sediment-water interface during stratification, likely causing the release of nutrients from the sediment. 
Woahink Lake

Recent measurements of primary productivity and densities of selected zooplankton species suggest that Woahink Lake has undergone eutrophication. The two primary productivity measurements made in 1992 are 1.1 and 1.8 times greater than the maximum rates measured during 1970-1972. A comparison of data from Larson and Salinas (1991 unpublished) and Malick (1971) for the total density of five zooplankton species showed that the lowest 1991 density was twice as large as the highest 1968-1969 density.

Data for chlorophyll a and dissolved oxygen on comparable dates show no apparent change over time. Chlorophyll a data for comparable dates and depths fall within $1.5 \mu \mathrm{g} / \mathrm{L}$ of each other. Although the largest chlorophyll a concentration was measured in an integrated sample collected in september 1989, I am uncertain as to how to compare results between integrated and discrete samples. Dissolved oxygen profiles measured since 1938 show hypolimnetic oxygen deficits and no evidence of changes in redox conditions over time.

The 1992 data for $\left[\mathrm{P}_{\mathrm{T}}\right]$ were below detection limits $(<.01 \mathrm{mg} / \mathrm{L})$ and are therefore limited in their use for comparison with previously collected data. Two of three measurements of $\left[\mathrm{P}_{\mathrm{T}}\right]$ reported by Johnson et al. (1985) are lower than a single measurement by Maloney et al. (1972) and lower than two measurements by Sweet (1990b). 
Data for Secchi Disk transparency and optical characteristics showed an improvement in water transparency. Secchi Disk depth has increased and decreased periodically since 1947. Secchi depth measurements from 1968 to 1972 are generally greater than measurements made in 1947 but less than measurements made during 1992 to 1993. Extinction coefficients calculated for 1992 data are smaller than one extinction coefficient calculated for 1969 .

Only the primary productivity and selected zooplankton data strongly suggest that eutrophication has occurred in Woahink Lake. The other data are inconclusive, appear stable, or show improved water quality over time. In conclusion, it is important to reiterate that detection of lake eutrophication and trends in water quality require the systematic collection of data over long periods of time. Otherwise, speculations about changes in water quality are made based on data that may or may not accurately reflect the seasonal and long term variability in limnological variables and the forces effecting them. 


\section{REFERENCES}

American Public Health Association. 1992. Standard Methods for the Examination of Water, Sewage, and Wastewater, 18th ed. American Public Health Association, New York.

Baldwin, E. M. 1976. Geology of oregon (revised edition). Kendall Hunt Publishing Co., Dubuque. 147 p.

Blair, M. S. and P. O. Nelson. 1993. Oregon coastal lakes study: phosphorus loading and water quality implications. Report for the oregon Department of Environmental Quality. 114 p.

Brooks, J. L. 1957. Systematics of North American Daphnia. Memoirs of the Connecticut Academy of Arts and Sciences. Vol. 13 .

Bryant, R. 1979. Lane county coastal lakes: Water quality report. Lane County Water Pollution Division, Eugene, OR. $60 \mathrm{p}$.

Burns, C. W. and J. J. Gilbert. 1986. Effects of daphnid size and density on interference between Daphnia and Keratella cochlearis. Limnol. Oceanogr. 31: 848-858.

Carlson, R. E. 1977. A trophic state index for lakes. Limnol. Oceanogr. 22: 361-369.

Chapman, D. W. and J. D. Fortune, Jr. 1963. Ecology of Kokanee salmon. Oregon Game Comm. Res. Div., Fishery Res. Rept.: 11-42.

Christensen, R. and G. Rosenthal. 1982. North Florence dunal aquifer study. Final report for the Lane county Council of Governments. $153 \mathrm{p}$.

Claska, M. E. 1988. The distribution of zooplankton in selected oregon lakes. M. S. Thesis. Portland state University. $91 \mathrm{p}$.

Cooper, S. D., and C. R. Goldman. 1980. Opossum shrimp (Mysis relicta) predation on zooplankton. Can. J. Fish. Aquat. Sci. 37: 909-919.

Daggett, S. G. and R. R. Petersen. 1993. oregon citizen lake watch program: 1992 final report. Submitted to the Oregon Dept. of Env. Quality. $78 \mathrm{p}$. 
-.-.- and -.---. 1994. Oregon citizen lake watch program: 1993 final report. Submitted to the oregon Dept. Of Env. Quality. 72 p.

Dodson, S. 1992. Predicting crustacean zooplankton species richness. Limnol. Oceanogr. 37: 848-856.

Edmondson, W. T. and G. G. Winberg. [eds.] 1971. A Manual on Methods for the Assessment of Secondary Productivity in Fresh Waters. IBP Handbook No. 17. Blackwell Scientific.

-.-.-. 1980. Secchi disk and chlorophyll. Limnol. oceanogr. 25: 378-379.

Evermann, B. W. and S. E. Meek. 1897. A report upon salmon investigations in the Columbia River Basin and elsewhere on the Pacific coast in 1896. Bull. U.S. Fish. Comm. 17: 15-84.

Frenkel, R. E. 1985. Vegetation, p. 58-66. In A. J. Kimerling and P. L. Jackson [eds.], Atlas of the Pacific Northwest, 7 th ed. Oregon State University Press.

Gahler, A. R. 1969. Sediment-water nutrient interchange, p. 243-257. In Proceedings of the EutrophicationBiostimulation Assessment Workshop, Berkeley, CA.

Gilbert, J. J. 1988. Suppression of rotifer populations by Daphnia: A review of the evidence, the mechanisms, and the effects on zooplankton community structure. Limnol. Oceanogr. 33: 1286-1303.

Griffiths, P. and E. D. Yeoman. 1938. A comparative study of oregon coastal lakes from a fish-management standpoint. Oregon Agricultural Experiment station Technical Paper No. 316: 323-333.

Hafele, R. and S. Roederer. 1987. An angler's guide to aquatic insects and their imitations: for all North America. Johnson Books, Boulder, CO. 179 p.

Hansen, D. J. 1963. The influence of natural mortality and other life history factors on the yield to the angler of planted cutthroat trout in Munsel Lake, oregon. M. S. thesis, Oregon State University. Corvallis, OR. $67 \mathrm{p}$.

Harris, G. P. 1986. Phytoplankton Ecology. University Press, Cambridge. 384 p. 
Hutchinson, G. E. 1967. A treatise on limnology, Vol. II, introduction to lake biology and the limnoplankton. John Wiley and Sons, New York. 1115 p.

Johnson, D. M. , R. R. Petersen, D. R. Lycan, J. W. Sweet, M. E. Neuhaus. 1985. Atlas of Oregon Lakes. Oregon state University Press, Corvallis, OR. $317 \mathrm{p}$.

Kavanagh, R. 1973. A comparative analysis of four oregon coastal lakes on the basis of description, trophy and density-dependent function. M. S. Thesis. Oregon state University, Corvallis, OR. $117 \mathrm{p}$.

Jackson, P. L. 1985. Climate, p. 48-47. In A. J. Kimerling and P. L. Jackson [eds.], Atlas of the Pacific Northwest. Oregon State University Press, Corvallis, OR.

Larson, D. W. 1970a. On reconciling lake classification with the evolution of four oligotrophic lakes in Oregon. Ph.D. dissertation. Oregon State University, Corvallis, OR. $145 \mathrm{p}$.

1970b. Limnological studies on the oregon coast. 1. Woahink Lake. Oregon State University Water Resources Research Institute Report No. 3 (WRRI-3). August, 1970. $40 \mathrm{p}$.

----. 1970c. Cultural impact on lake evolution. Seminar presented by Oregon State University Water Resources Research Institute. Corvallis, OR. $13 \mathrm{p}$.

----. 1972. Comparative limnology and phytoplankton ecology of four "oligotrophic" lakes in oregon, U.S.A., with emphasis on lake typology. NW Science 46: 149-162.

----. 1974. A water quality survey of selected coastal lakes in the sand dune region of western Lane and Douglas Counties 1972-1973. Final Report. State of Oregon Department of Environmental Quality, Portland, OR. $120 \mathrm{p}$.

- 1991. Oregon dunal lakes unique in the northern hemisphere. The Oregonian. September 8, 1991.

-----, and J. Salinas. 1991. Unpublished data from Mercer Lake, Munsel Lake, and Woahink Lake.

Malick, J. G. 1971. Population dynamics of selected zooplankton in three oligotrophic oregon lakes. M. S. thesis. Oregon State University, Corvallis, OR. 112 p. 
Maloney, T. E., W. E. Miller, T. Shiroyama. 1972. Algal responses to nutrient additions in natural waters. I. laboratory assays, 1: 134-140. In G. E. Likens [ed.], Limnol. Oceanog. Spec. Symp. on Nutrients and Eutrophication.

Margalef, R. 1980. La Biosfera, Ediciones Omega, Barcelona. In G. P. Harris., Phytoplankton Ecology. 1986. University Press, Cambridge. 384 p.

McConnaughey, B. H., and E. McConnaughey. 1980. Pacific Coast: the Audubon Society nature guides. Alfred Knopf, New York. $633 \mathrm{p}$.

McGie A. M., and R. Breuser. 1962. Coastal lake studies, Part XI. Woahink Lake. Oregon Fish Comm. Res. Div. Rept. $12 \mathrm{p}$.

McGie, A. M. 1964a. Evaluation of coho salmon plants in coastal lakes (information report). Oregon Fish Comm. Proc. Rept., Coastal Rivers. $6 \mathrm{p}$.

----. 1964b. Coastal lakes survey program with special emphasis on studies conducted at Hall and Schuttpelz Lakes. Oregon Fish Comm. Proc. Rept. Coastal Rivers. $8 \mathrm{p}$.

McHugh, R. 1972, 1973, 1979, 1980. Unpublished phytoplankton data for Mercer Lake, Munsel Lake, and Woahink Lake.

Merritt, R. W. and K. W. Cummins, [eds.], 1984. An Introduction to Aquatic Insects of North America, 2nd ed. Kendall/Hunt, Dubuque, IA. 722 p.

Miller, W. E., T. E. Maloney, and J. C. Greene. 1974 . Algal productivity in 49 lakes as determined by algal assays. Water Res. 8: 667-679.

Oakley, A. L. 1962a. Coastal lake studies, Part VI. Mercer Lake. Oregon Fish Comm. Res. Div. Rept. 24 p.

-----. 1962b. Coastal lake studies, Part VII. Munsel Lake. Oregon Fish Comm. Res. Div. Rept. 24 p.

Pennak, R. W. 1989. Fresh-water Invertebrates of the United States: Protozoa to Mollusca, 3rd ed. Wiley. $628 \mathrm{p}$.

Phinney, H. K. and J. L. McLachlan. 1956. Aquatic weed survey of Oregon. Oregon Ag. Exp. Stn. Misc. Paper No. 30. $85 \mathrm{p}$. 
Prescott, G. W. 1978. How to Know the Freshwater Algae, 3 rd ed. Brown. Dubuque, IA. 293 p.

Rodhe, w. 1969. Crystallization of eutrophication concepts in northern Europe, p. 50-46. In: Proceedings of an International symposium on Eutrophication Causes, Consequences, Correctives, Madison, Wisconsin, 1967. (National Academy of Sciences, Washington, D.C.).

Saltzman, w. O. 1961. A compilation of data from Mercer and Sutton Lakes, Lane County, Oregon. Oregon Game Comm. Rept. 25 p.

----. 1962. A compilation of data from Woahink Lake, Lane County, Oregon. Oregon Game Comm. Rept. 24 p.

Schlicker, H. G., and R. C. Newcomb. 1974. Environmental geology of coastal Lane County, Oregon. Oregon Dept. of Geology and Mineral Industries, Portland, or. 8 p.

Schneider, D. W. 1990. Direct assessment of the independent effects of exploitative and interference competition between Daphnia and rotifers. Limnol. Ocean. 35: 916-922.

Skeesick, D. G. 1965. Catch, migration, growth, and survival of stocked coastal cutthroat trout in Munsel Lake, Oregon. Oregon Game Comm. Res. Div., Fish Res. Rept. No. 2 Proj. No. F-72-R-1. 37 p.

- 1969. Spawning $f$ ish surveys in coastal watersheds, 1968. Oregon Fish Comm. Proc. Rept., Coastal Rivers. $62 \mathrm{p}$.

1970a. Spawning fish surveys in coastal watersheds, 1969. (Information Report 70-1). State of Oregon Fish Commission Proc. Rept., Coastal Rivers. $52 \mathrm{p}$.

1970b. Coastal lakes as possible water sources for a coho hatchery (Information Report 69-2). Oregon Fish Comm. Proc. Rept., Coastal Rivers. 41 p.

-----, and T. F. Gaumer. 1969. Potential hatchery sites on Oregon coastal streams. Oregon Fish Comm. Proc. Rept., Coastal rivers. 66 p.

and -----. 1970. Potential hatchery sites on Oregon coastal streams (appendices). Oregon Fish Comm. Proc. Rept., Coastal rivers. $117 \mathrm{p}$. 
Smith, W. D., and W. Greenup. 1939. Lakes of Oregon. NW Science 13: 76-96.

Sweet, J. W. 1986. A survey and ecological analysis of oregon and Idaho phytoplankton. Report submitted to the Environmental Protection Agency, Seattle, WA.

-----. 1990a. Mercer Lake water quality report. Prepared for the Oregon Dept. of Env. Quality, Portland, OR. $23 \mathrm{p}$.

----. 1990b. Woahink Lake water quality report. Prepared for the Oregon Dept. of Env. Quality. Portland, OR. 23 p.

Terrell, C. R. and P. B. Perfetti. 1991. Water quality indicators guide: surface waters. U.S. Dept. of Agriculture. Soil Cons. Serv. Pub. No. SCS-TP-161. $129 \mathrm{p}$.

Threlkeld, S. T. 1979. Estimating cladoceran birth rates: the importance of egg mortality and the egg age distribution. Limnol. Oceanogr. 24: 601-612.

-.--. 1981. The recolonization of Lake Tahoe by Bosmina longirostris: Evaluating the importance of reduced Mysis relicta populations. Limnol. Oceanogr. 26: 433444 .

Weatherbee, J. 1990. The status of Mysis in oregon. Oregon Dept. of Fish and Wildlife Rept. 20 p.

Weber, C. I., L. A. Fay, G. B. Collins, D. E. Rathke, J. Tobin. 1986. A review of methods for the analysis of periphyton and plankton of marine and freshwater systems. Technical Bulletin OHSU-TB-15. Ohio State University Sea Grant Program.

Wetzel, R. G. 1983. Limnology, 2nd ed. Saunders. 767 p.

Wetzel, R. G., and G. E. Likens. 1991. Limnological Analyses, 2nd ed. Springer-Verlag. 391 p. 


\section{APPENDIX A}

METHODS FOR MEASUREMENT OF PRIMARY PRODUCTIVITY, AND ANALYSIS OF CHLOROPHYLL $\underline{a}$, PHYTOPLANKTON, AND ZOOPLANKTON 


\section{Phytoplankton Primary Productivity}

Larson (1970a) describes the method used for primary productivity measurements as follows:

Phytoplankton primary productivity was measured in situ with ${ }^{14} \mathrm{C}$. The method used was a modification of a 1961 technique prepared by the Fisheries Research Institute, University of Washington, Seattle (F.R.I. field manual, section S6, carbon-14). Water samples were collected at station... with a $21 / 2$ liter plastic water bottle (Van Dorn type). Sampling depths were variable in each lake . . . A 125 ml-portion of water from each sampling depth was inoculated with $1 \mathrm{ml}$ of a stock solution of $\mathrm{Na}_{2}{ }^{14} \mathrm{CO}_{3}(5.0 \mu \mathrm{Ci} / \mathrm{ml})$ and returned to the depth from which it was drawn. Dark bottles accompanied light bottles at every other depth to determine nonphotosynthetic uptake of ${ }^{14} \mathrm{C}$. occasionally, duplicate light bottles were added to assess experimental error. Following a four-hour incubation period $(1000-1400 \mathrm{hrs})$, all samples were retrieved and filtered with a Millipore apparatus (47 mm-diameter AA Millipore filters) in the mobile laboratory. The uptake of ${ }^{14} \mathrm{C}$ was determined by liquid scintillation counting at oregon State University. Net production rates $\left(\mathrm{mg} \mathrm{c} / \mathrm{m}^{3} / \mathrm{hr}\right.$ ) were plotted against depth for each sampling date. The resulting curves were integrated and net production rates for the sampled water column were estimated for the incubation period (mg $\mathrm{c} / \mathrm{m}^{2} / \mathrm{hr}$ ).

Measurements of carbon fixed per incubation period were converted to approximate daily values. This was done by dividing the 4-hr in situ production measurements by an appropriate energy fraction (Function F; Vollenweider, 1965). An energy fraction was that portion of the total daily radiation which was incident during the incubation period (Platt and Irwin, 1968). . . .

In 1991, the uptake of ${ }^{14} \mathrm{C}$ was determined by Dr. Marv Lilley using liquid scintillation counting at the University of Washington. The samples were counted for 10 minutes in a Packard Instruments Minaxi Tri Carb 4000 series scintillation counter using a cytoscint scintillation cocktail. 
Chlorophyll a field and laboratory methods

Water samples were collected with a Van Dorn bottle. In an effort to determine the most effective method for storing water samples for chlorophyll a analysis, three different storage methods were used during June 1992. With the first method, chlorophyll water samples were transferred to translucent $250 \mathrm{~mL}$ HDPE Nalgene bottles and immediately stored on ice. Within 8 hours $100-250 \mathrm{~mL}$ of sample was filtered, out of direct sunlight, through a $47 \mathrm{~mm}$ Millipore GF/F filter using the lowest vacuum possible with a hand pump. Filters were placed individually in Petri slides and saturated with $3-5$ drops of saturated $\mathrm{MgCO}_{3}$ solution. Petri slides were wrapped in aluminum foil and stored on ice while in the field, for a maximum of five days. In the laboratory, they were stored in a freezer at approximately $-15^{\circ} \mathrm{C}$ until analysis.

Using the second method (Department of Environmental Quality Methods of Analysis for Chlorophyll a), samples were collected in translucent $250 \mathrm{~mL}$ bottles, stored on ice and filtered in the shade. GF/F filters were used instead of the membrane filters specified in the DEQ procedure. The filters were then rolled up and placed in screw-top test tubes containing approximately $6 \mathrm{~mL}$ of aqueous acetone buffered with $\mathrm{MgCO}_{3}$ and $\mathrm{NaHCO}_{3}$. The test tubes were capped tightly and stored on ice in the dark while in the field, for a maximum of five days. In the lab, they were stored in 
a freezer at approximately $-15^{\circ} \mathrm{C}$ until analysis.

Chlorophyll a samples were also preserved in accordance with methods selected from the Ohio sea Grant Program's review of methods for chlorophyll analysis (Weber et al., 1986). Using this method, samples were transferred to 250 $\mathrm{mL}$ opaque amber bottles containing $2.5 \mathrm{~mL}$ of saturated $\mathrm{MgCO}_{3}$. The samples were stored on ice and later filtered in very low light. In the field, low light conditions were achieved by completing the filtration in a dimly lit tent or by wrapping all the filter apparatus in aluminum foil.

Filtered samples were rolled up and stored in screw-top test tubes containing aqueous acetone. Test tubes were stored on ice, for a maximum of 5 days, until they could be stored in a $-15{ }^{\circ} \mathrm{C}$ freezer.

It was not determined statistically which method provided more reliable chlorophyll a concentrations. A decision was made to exclusively use the filter storage method derived from the Ohio sea Grant Program, as described above, during July 1992 .

In the laboratory, the samples were analyzed by following, with slight modifications, the DEQ Laboratory procedures for analysis of chlorophyll. Each filter was ground with a glass mortar and a teflon pestle with aqueous acetone as the solvent. The ground filter and aqueous acetone mixture was transferred to a $15 \mathrm{~mL}$ centrifuge tube, vortexed for 10 seconds, and returned to the freezer. After 
24 hours, the centrifuge tube was removed from the freezer and allowed to warm to room temperature. Each tube was then centrifuged at 3000 rpms for 10 minutes and a portion of the supernatant was poured into a screw-top test tube. The supernatant was analyzed fluorometrically before and after the addition of $1 \mathrm{~N} \mathrm{HCl}$. The addition of $\mathrm{HCl}$ changed all the chlorophyll a to pheophytin a, a principal degradation product of chlorophyll a, and allowed the calculation of chlorophyll a concentrations corrected and not corrected for the presence of pheophytin a. The resulting fluorometer readings were then converted into chlorophyll $\underline{a}$ concentrations in $\mu \mathrm{g}$ liter $^{-1}$ using equations that include chlorophyll a standards values obtained by fluorometrically analyzing pure chlorophyll a obtained from the DEQ

Laboratory. The chlorophyll a data reported for 1992 are corrected for the presence of pheophytin $\underline{a}$.

\section{Phytoplankton Identification and Enumeration}

In a letter accompanying the report of phytoplankton analyses, Jim Sweet described his procedures for counting and identifying the samples as follows:

Permanent microscope slides are prepared from each sample by filtering an appropriate aliquot of the sample through a 0.45 micrometer membrane filter (McNabb, 1960). A section is cut out and placed on a glass silde with immersion oil added to make the filter transparent, followed by placing a cover slip on top, with nail polish applied to the periphery for permanency. A benefit to this method is that samples can be archived indefinitely; we have over 8,000 slides 
archived.

Algal units (defined as discrete particles - either cells, colonies, or filaments) are counted along a measured transect of the microscope slide with a zeiss standard microscope (1000X, phase contrast). Only those algae that were believed to be alive at the time of collection (intact chloroplast) are counted. A minimum of 100 algal units are counted.

Average biovolume estimates of each species are obtained from calculations of microscopic measurements of each alga. The number of cells per colony, or the length of a filament, are recorded during sample analysis to arrive at biovolume per unit-alga. Average biovolumes for most algae are stored in a computer; measurements are verified, but biovolumes are not calculated for each sample analyzed.

Aquatic Analysts use a Zeiss Standard phase-contrast microscope primarily with a 1000X magnification for identification and enumeration of algal samples. The diameter of the field of view at $1000 \mathrm{X}$ magnification is $0.182 \mathrm{~mm}$. The effective area of a filter is $201 \mathrm{~mm}^{2}$.

Algae are enumerated along a measured transect, measured accurately to $0.1 \mathrm{~mm}$ with a stage micrometer. The algal densities are calculated from the area observed (transect length times diameter of field of view), the effective filter area, and the volume of sample filtered.The microscope was calibrated using a standard concentration of latex spheres provided by EPA (Cincinnati, $\mathrm{OH}$ ). The concentration of these spheres was 12,075 per milliliter. Duplicate preparations of the standard spheres were analyzed; the average result was 11,700 spheres per milliliter (96.9 percent). The BASIC computer program used to calculate algal densities was adjusted to compensate for this 3.1 percent error.

A Trophic State Index based upon phytoplankton biovolume has been developed from a data set of several hundred lakes located throughout the Pacific Northwest (Sweet, 1986, Report to EPA). The index was derived in a similar fashion as Carlson (1977) derived indices for Secchi depth, chlorophyll concentration, and total phosphorus concentration. The biovolume index ranges from 1 for ultraoligotrophic lakes to 100 for hypereutrophic lakes; values agree well with Carlson's indices.

The index is defined as:

TSI (biovolume) $=($ Log-base $2(B+1)) * 5$

Where $B$ is the phytoplankton biovolume in cubic micrometers per milliliter divided by 1000 . 
A similarity index is useful in comparing phytoplankton communities between two samples. The index compares the relative abundances of each species present in two samples and yields a value ranging from 0 for totally dissimilar samples, to 100 for identical samples. The formula for the index (modified from Whittaker, 1967) is:

Similarity Index $=100-($ Sum of DIFFERENCE $/ 2)$

Where DIFFERENCE is the absolute value of the difference of the percent of a given species in two samples.

Each Sample Report Sheet includes a Shannon-Weaver diversity index (log base 2 ).

\section{Zooplankton Identification and Enumeration}

In a letter accompanying the report of zooplankton analyses, Allan Vogel described his procedures for counting and identifying the samples as follows:

The samples were split until an approximate subsample size of 400 total individuals and 100 individuals of the most abundant species was reached. If the initial split did not achieve both of these criteria, then increasingly larger splits were enumerated until both criteria were met, or until the entire sample was counted (none of the samples in this study fell under this exception). The statistical methodology for this approach is based upon Edmondson and Winberg (1971, p. 178), and assumes that the sampling methods (both in the field and during the splitting) follow a Poisson distribution. This assumption is violated for larger species, thus, all individuals of those species within a sample are always enumerated. Field sampling of such species seriously undercollects them however, so their measured densities will always be lower than their actual density in the field despite the laboratory correction. The selected values of 400 and 100 individuals provide a maximum statistical standard error of the mean of 5 and 10 percent, respectively (The formula used is: $s=1 / N$ ). While only the confidence limits for total numbers and most abundant species are set by this procedure, the standard error of the mean for each species can be determined by backcalculation using the total numbers originally $t$ 
tallied.

The samples were enumerated using a wild $\mathrm{M}-3$ microscope at $32 \mathrm{x}$ magnification. Species identifications were made at higher levels of magnification as needed. General taxonomic identifications followed Edmondson (1959), Pennak (1989), and Thorp and Covich (1991). Specific group references included Brooks (1957), Brandlova, Brandl, and Fernando (1972), Deevey and Deevey (1971), Pontin (1978), and stemberger (1979). Identifications were to species for all crustaceans except harpacticoid copepods and for most rotifers. In the final density data table, (?) indicates an uncertain species identification.

The seven digit numerical species code in the column to the right of the species name is derived from the NODC (U.S. National Oceanic Data Center) codes for marine species. This standardized, but unofficial, code has been included to allow for data manipulation by software programs which cannot directly handle species names. 


\section{APPENDIX B}

\section{OPTICAL CHARACTERISTICS}




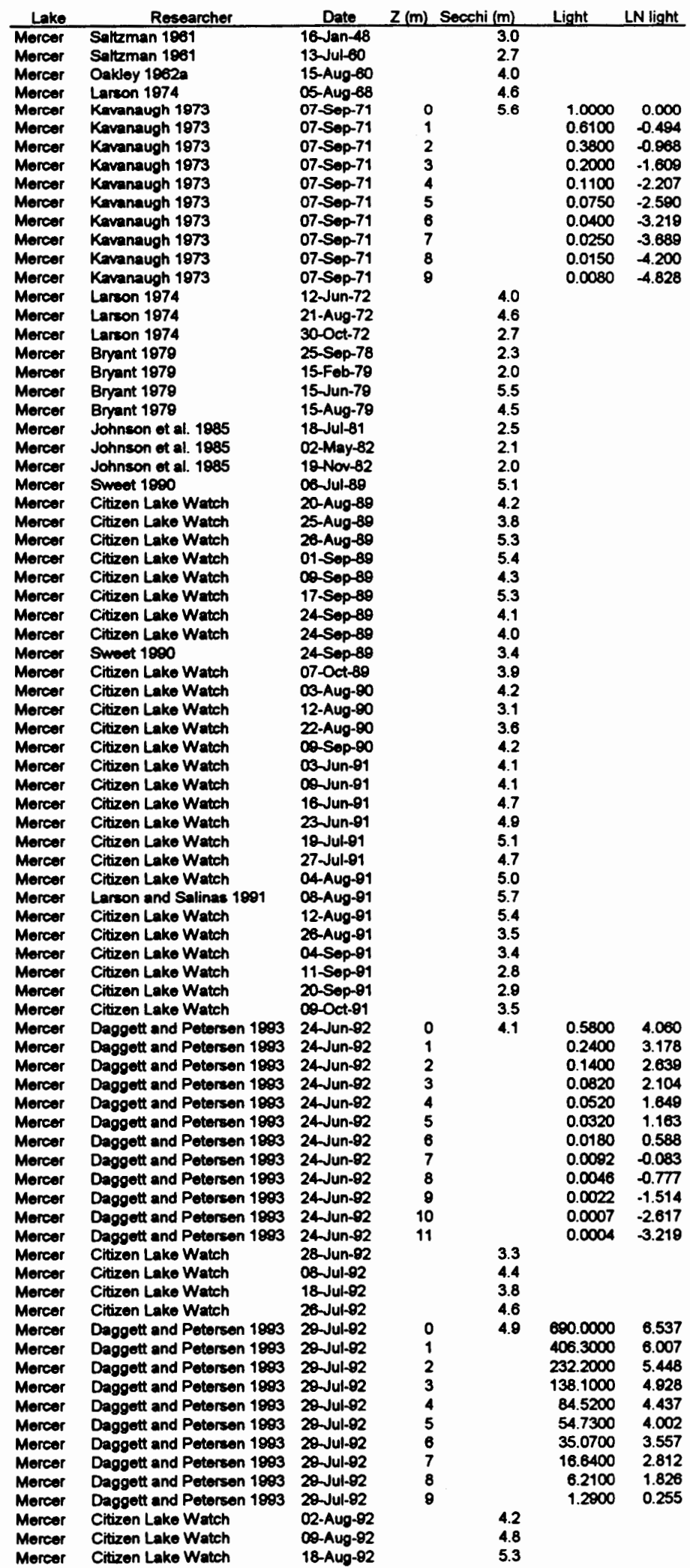




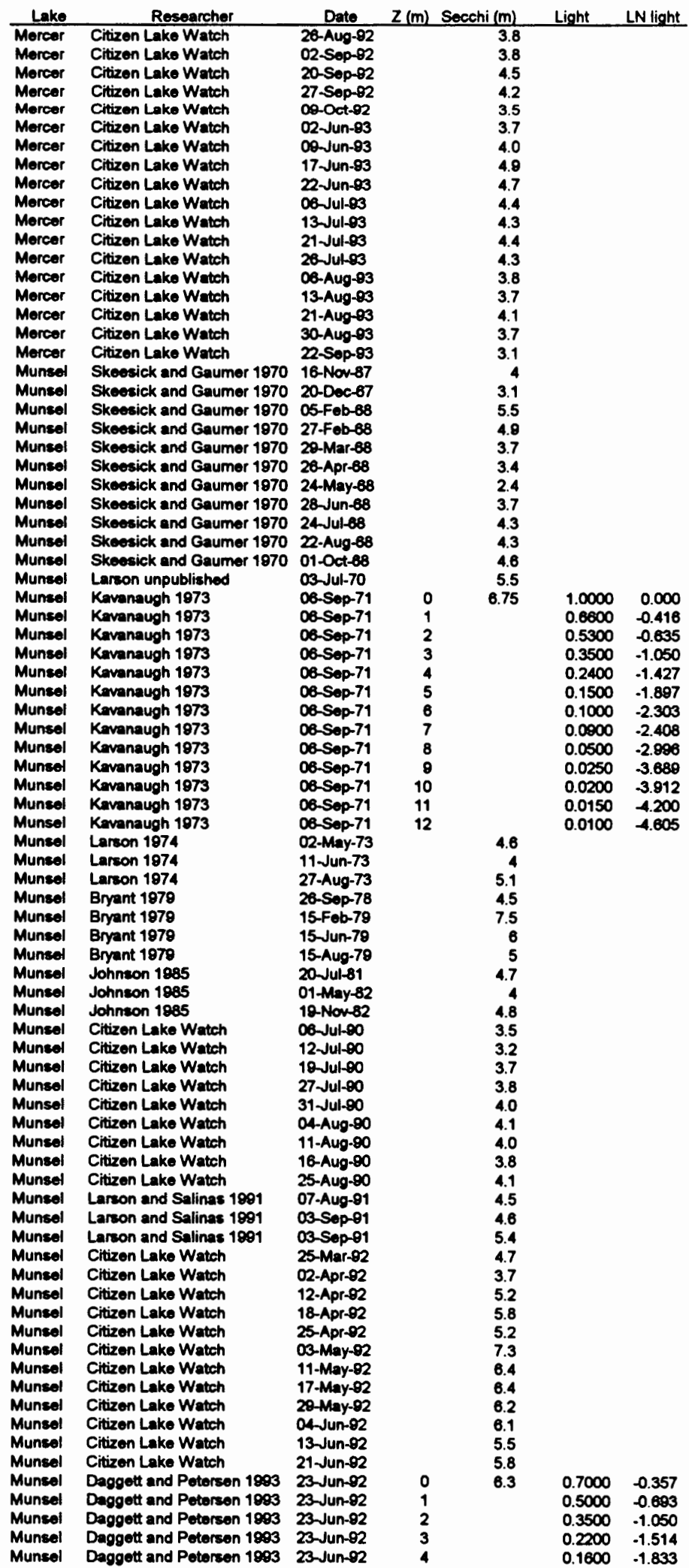




\begin{tabular}{|c|c|c|c|c|c|c|}
\hline Lake & Researcher & Date & $Z(m)$ & Secchi (m) & Light & LN light \\
\hline Munsel & Dagget and Petersen 1983 & 23-Jun-92 & 5 & & 0.1100 & -2.207 \\
\hline Munsel & Daggett and Petersen 1993 & 23-Jun-02 & 6 & & 0.0730 & -2.617 \\
\hline Muncel & Daggett and Petorsen 1993 & 23-Jun-82 & 7 & & 0.0480 & -3.037 \\
\hline Muncel & Daggett and Peterien 1893 & 23-Jun-92 & 8 & & 0.0320 & -3.442 \\
\hline Muncel & Daggett and Petersen 1993 & 23-Jun-92 & 9 & & 0.0200 & .3 .812 \\
\hline Muneel & Daggett and Potersen 1993 & 23-Jun-82 & 10 & & 0.0110 & -4.510 \\
\hline Munsel & Daggett and Petercen 1993 & 23-Jun-92 & 11 & & 0.0056 & -5.185 \\
\hline Muncel & Daggett and Petersen 1993 & 23-Jun-82 & 12 & & 0.0037 & .5 .599 \\
\hline Munsed & Deggett and Petersen 1993 & 23-Jun-92 & 13 & & 0.0023 & -6.075 \\
\hline Munsel & Daggett and Potersen 1993 & 23-Jun-92 & 14 & & 0.0014 & -6.571 \\
\hline Munsel & Daggett and Petersen 1993 & 23-Jun-92 & 15 & & 0.0000 & .7 .013 \\
\hline Munsed & Deggett and Petersen 1993 & $23-J u n-92$ & 18 & & 0.0006 & .7 .419 \\
\hline Muncel & Daggett and Potersen 1993 & 23-Jun-92 & 17 & & 0.0004 & -7.824 \\
\hline Muneal & Daggett and Petersen 1983 & 23-Jun-92 & 18 & & 0.0002 & -8.517 \\
\hline Munsel & Daggett and Petersen 1893 & 23-Jun-82 & 19 & & 0.0002 & -8.517 \\
\hline Muneal & Citizen Lake Watch & 30-Jun-92 & & 5.5 & & \\
\hline Muneel & Citizen Lake Watch & 08-Jui-92 & & 5.3 & & \\
\hline $\begin{array}{l}\text { Munsel } \\
\text { Munsel }\end{array}$ & $\begin{array}{l}\text { Citizen Lake Watch } \\
\text { Citizen Lake Watch }\end{array}$ & $\begin{array}{l}\text { 17-Jut-82 } \\
23-J u t-82\end{array}$ & & $\begin{array}{l}6.4 \\
5.5\end{array}$ & & \\
\hline Munsel & Daggett and Petersen 1993 & $28-\mathrm{Jul}-92$ & 0 & 5.1 & 1160.0000 & 7.056 \\
\hline Munsel & Daggott and Petersen 1983 & 28-Jul-92 & 1 & & 853.3000 & 6.740 \\
\hline Muncel & Dagget and Petersen 1993 & 28-Jul-92 & 2 & & 592.4000 & 6.384 \\
\hline Munsol & Daggett and Petersen 1893 & 28 Jul-92 & 3 & & 430.0000 & 6.084 \\
\hline Munsel & Daggett and Potersen 1993 & 28-Jul-92 & 4 & & 331.5000 & 5.804 \\
\hline Munsel & Daggott and Petersen 1993 & 28-Jul-92 & 5 & & 227.1000 & 5.425 \\
\hline Munsel & Daggett and Petersen 1993 & 28-Jul-92 & 6 & & 165.1000 & 5.107 \\
\hline Munsel & Daggett and Petersen 1993 & $28-J u l-82$ & 7 & & 116.0000 & 4.761 \\
\hline Munsel & Daggett and Petersen 1903 & 28-Jul-92 & 8 & & 84.5800 & 4.437 \\
\hline Munsel & Daggett and Petersen 1993 & 28-Jul-02 & $\boldsymbol{9}$ & & 55.3200 & 4.013 \\
\hline Munsel & Citizen Lake Watch & $31-J u l-92$ & & 4.9 & & \\
\hline Muncel & Citizen Lake Watch & 07-Aug-92 & & 5.5 & & \\
\hline Muncel & Citizen Lake Watch & 15-Aug-02 & & 6.8 & & \\
\hline Munsel & Citizen Lake Watch & 22-Aug-92 & & 5.8 & & \\
\hline Munsel & Citizen Lake Watch & 30-Aug-82 & & 5.5 & & \\
\hline Munsel & Citizen Lake Watch & 14-Sop-92 & & 5.8 & & \\
\hline Munsel & Citizen Lake Watch & $20-5$ ep-92 & & 5.8 & & \\
\hline Munsel & Citizen Lake Watch & 11-Oct-82 & & 5.8 & & \\
\hline Munsel & Citizen Lake Watch & 29-May-93 & & 7.4 & & \\
\hline Munsel & Citizen Lake Watch & 06-Jun-83 & & 5.5 & & \\
\hline Muncel & Citizen Lako Watch & 13-Jun-93 & & 4.6 & & \\
\hline Munsel & Citizen Lake Watch & 22-Jun-93 & & 5.3 & & \\
\hline Munsel & Citizen Lake Watch & 08-Jul-03 & & 5.2 & & \\
\hline Munsel & Citizen Lake Watch & 18-Jul-93 & & 4.0 & & \\
\hline Munsel & Citizen Lake Watch & 23-Jul-93 & & 5.8 & & \\
\hline Munsel & Citizen Lake Watch & $02-A u 0-83$ & & 5.5 & & \\
\hline Muncel & Citizen Lake Watch & O8-Aug-83 & & 5.5 & & \\
\hline Munsel & Citizen Lake Watch & 17-Aug-93 & & 4.6 & & \\
\hline Munsel & Citizen Lake Watch & 24-Aug-83 & & 5.8 & & \\
\hline Munsel & Citizen Lake Watch & 31-Aug-83 & & 4.8 & & \\
\hline Munsel & Citizen Lake Watch & 21-Sep-83 & & 5.5 & & \\
\hline Woahink & Saltzman 1862 & 24-Nov-47 & & 4.6 & & \\
\hline Woahink & Saltzman 1962 & OS-Dec-47 & & 5.5 & & \\
\hline Woahink & McGie and Breuser 1962 & 16-Aug-60 & & 3.7 & & \\
\hline Woahink & Lareon 1970 & 26-Jun-68 & & 6.4 & & \\
\hline Woahink & Larson 1970 & 17-Jul-68 & & 5.8 & & \\
\hline Woahink & Larson 1970 & 06-Aug-68 & & 6.4 & & \\
\hline Woahink & Larson 1970 & 03-Sop-68 & & 6.1 & & \\
\hline Woahink & Larcon 1970 & 12Sop-68 & & 5.2 & & \\
\hline Woahink & Larson 1970 & 12-Nov-68 & & 7.3 & & \\
\hline Woahink & Larson 1970 & 02Dec-68 & & 6.4 & & \\
\hline Woahink & Larson 1970 & 24-Fob-69 & & 6.7 & & \\
\hline Woahink & Larson 1970 & 14-Apr-69 & & 6.4 & & \\
\hline Woahink & Larson 1870 & 10-May- 69 & & 7.3 & & \\
\hline Woahink & Larson 1970 & 26-May- 69 & & 6.7 & & \\
\hline Woahink & Larson 1970 & 13Jun-69 & 0 & 6.4 & 1.0000 & 0.000 \\
\hline Woahink & Larson 1970 & 02 Jul-69 & 1 & & 0.7220 & -0.326 \\
\hline Woahink & Larson 1970 & O2-Jul-69 & 3 & & 0.3130 & -1.162 \\
\hline Woahink & Larson 1970 & 02-Jul-69 & 5 & & 0.2030 & -1.595 \\
\hline Woahink & Larson 1870 & 02 Jul-69 & 7 & & 0.1210 & -2.112 \\
\hline Woahink & Larson 1970 & 02 Jul-69 & 10 & & 0.0380 & -3.270 \\
\hline Woahink & Lareon 1970 & $02-J u l-\infty 9$ & 14 & & 0.0110 & -4.510 \\
\hline Woahink & Larson 1970 & 02-Jul-69 & 20 & & 0.0020 & -6.215 \\
\hline Woahink & Larson 1970 & $01-A u g-69$ & & 5.5 & & \\
\hline Woahink & Larson 1970 & 03-Sop-69 & & 5.5 & & \\
\hline Woahink & Lerson 1870 & 28-Sep-60 & & 4.6 & & \\
\hline Woahink & Larson 1974 & 12ปJun-72 & & 5.5 & & \\
\hline Woahink & Larson 1974 & 21-Aug-72 & & 7.3 & & \\
\hline Woohink & Larson 1974 & $30-0 c t-72$ & & 5.5 & & \\
\hline Woahink & Bryant 1978 & 15-Feb-79 & & 6 & & \\
\hline Woahink & Bryant 1979 & 15-Jun-78 & & 5 & & \\
\hline Woahink & Bryant 1879 & 15-Aug-78 & & 5.5 & & \\
\hline Woshink & Johnson 1885 & 28-Jul-81 & & 5.8 & & \\
\hline
\end{tabular}




\begin{tabular}{|c|c|c|c|c|c|c|}
\hline Lake & Researcher & Date & $Z(m)$ & Secchi $(m)$ & Light & LN light \\
\hline Woahink & Johneon 1885 & $02-$ May-82 & & 5 & & \\
\hline Woshink & Johnson 1885 & 20-Nov-82 & & 4.7 & & \\
\hline Woahink & Citizen Lake Watch & 07-Jul-88 & & 7.3 & & \\
\hline Woahink & sweet 1990 & 07-Jui-89 & & 5.9 & & \\
\hline Woahink & Citizen Lake Watch & $19-J u l-8 \theta$ & & 3.8 & & \\
\hline Woahink & Citizen Lake Watch & 29-Jul-89 & & 4.1 & & \\
\hline Woahink & Citizen Lake Watch & 15-Aug-89 & & 4.7 & & \\
\hline Woahink & Citizen Lake Watch & $28-A$ ug -89 & & 5.1 & & \\
\hline Woahink & Citizen Lake Watch & 22-Aug-88 & & 6.2 & & \\
\hline Woahink & Citizen Lake Watch & $30-A u g-89$ & & 5.6 & & \\
\hline Woahink & Citizen Lake Watch & $01.5 e p-8 \theta$ & & 5.7 & & \\
\hline Woahink & Citizen Lake Watch & $06-5 e p-8 \theta$ & & 4.5 & & \\
\hline Woahink & Citizen Lake Watch & $10-5 e p-8 \theta$ & & 4.4 & & \\
\hline Woahink & Citizen Lake Watch & $11-\operatorname{Sep}-89$ & & 6.1 & & \\
\hline Woahink & Citizen Lake Watch & $20-$ Sep-89 & & 5.3 & & \\
\hline Woahink & Citizen Lake Watch & 24-Sep-89 & & 6.9 & & \\
\hline Woahink & Swoot 1990 & 24-Sop-89 & & 4.9 & & \\
\hline Woahink & Citizen Lake Watch & 27-Sep-88 & & 5.5 & & \\
\hline Woahink & Citizen Lake Watch & $05-0 c t-8 \theta$ & & 4.7 & & \\
\hline Woahink & Citizen Lake Watch & $13-0 c t-89$ & & 4.4 & & \\
\hline Woahink & Citizen Lake Watch & 16-NON-89 & & 4.2 & & \\
\hline Woahink & Citizen Lake Watch & 02-Doc-89 & & 4.6 & & \\
\hline Woahink & Citizen Lake Watch & 17 Jan- -0 & & 4.9 & & \\
\hline Woahink & Citizen Lake Watch & 18-Feb- 00 & & 5.1 & & \\
\hline Woahink & Citizen Lake Watch & $10-$ Mar-80 & & 4.9 & & \\
\hline Woahink & Citizen Lake Watch & $30-A p r-90$ & & 4.2 & & \\
\hline Woahink & Citizen Lake Watch & $11-$ May-90 & & 3.7 & & \\
\hline Woahink & Citizen Lake Watch & $19-$ May-e0 & & 3.9 & & \\
\hline Woahink & Citizen Lake Watch & 07-Jun-90 & & 4.1 & & \\
\hline Woahink & Citizen Lake Watch & 26-Jun-80 & & 3.7 & & \\
\hline Woahink & Citizen Lake Watch & 04-Jul-80 & & 4.1 & & \\
\hline Woahink & Citizen Lake Watch & 10 Jul-90 & & 3.8 & & \\
\hline Woahink & Citizen Lake Watch & 12 Jul-90 & & 4.7 & & \\
\hline Woahink & Citizen Lake Watch & $22-J u l=00$ & & 4.7 & & \\
\hline Woahink & Citizen Lake Watch & $28-J u l-\infty 0$ & & 4.7 & & \\
\hline Woahink & Citizen Lake Watch & $01-A u g-\infty 0$ & & 4.8 & & \\
\hline Woahink & Citizen Lake Watch & OB-Aug-OO & & 5.0 & & \\
\hline Woahink & Citizen Lake Watch & 15-Aug-e0 & & 5.7 & & \\
\hline Woahink & Citizen Lake Watch & 21-Aug-80 & & 5.7 & & \\
\hline Woahink & Citizen Lake Watch & 20-Aug-80 & & 5.6 & & \\
\hline Woahink & Citizen Lake Watch & 05-Sep-80 & & 5.3 & & \\
\hline Woahink & Citizen Lake Watch & $10-$ Sop-80 & & 5.3 & & \\
\hline Woahink & Citizen Lake Watch & 18-Sep-80 & & 5.6 & & \\
\hline Woahink & Citizen Lake Watch & 25-5op-80 & & 5.3 & & \\
\hline Woahink & Citizen Lake Watch & $10-0 c t-60$ & & 5.0 & & \\
\hline Woahink & Citizen Lake Watch & $16-0 c t-60$ & & 5.2 & & \\
\hline Woahink & Citizen Lake Watch & $21-0 c t-80$ & & 5.1 & & \\
\hline Woahink & Citizen Lake Watch & 24-Jun-91 & & 4.2 & & \\
\hline Woahink & Citizen Lake Watch & $01-J u t-91$ & & 4.6 & & \\
\hline Woahink & Citizen Lake Watch & obJul-91 & & 4.2 & & \\
\hline Woahink & Citizen Lake Watch & 15-Jul-91 & & 3.6 & & \\
\hline Woahink & Citizen Lake Watch & 30-JuL-91 & & 4.7 & & \\
\hline Woahink & Larson and Salinas 1991 & 05-Aug-91 & & 5.4 & & \\
\hline Woahink & Citizen Lake Watch & 07-Aug-81 & & 4.5 & & \\
\hline Woahink & Citizen Lake Watch & 14-Aug-91 & & 4.8 & & \\
\hline Woahink & Citizen Lake Watch & 20-Aug-91 & & 5.2 & & \\
\hline Woahink & Citizen Lake Watch & 03-Sop-01 & & 4.8 & & \\
\hline Woahink & Larson and Salinas 1991 & 04-Sop-01 & & 6.6 & & \\
\hline Woahink & Citizen Lake Watch & 10-Sep-01 & & 5.0 & & \\
\hline Woahink & Citizen Lake Watch & 17.Sep-91 & & 5.1 & & \\
\hline Woahink & Citizen Lake Wetch & $07-0 c t-81$ & & 4.6 & & \\
\hline Woahink & Citizen Lake Watch & 11-Nov-91 & & 5.2 & & \\
\hline Woahink & Citizen Lake Watch & 19-Dec-01 & & 6.2 & & \\
\hline Woahink & Citizen Lake Watch & 14Jan-92 & & 5.8 & & \\
\hline Woahink & Citizen Lake Watch & 24-Feb-92 & & 6.2 & & \\
\hline Woahink & Citizen Lake Watch & 21-Mar-02 & & 5.8 & & \\
\hline Woahink & Citizen Lake Watch & 31-Mar-92 & & 5.2 & & \\
\hline Woahink & Citizen Lake Watch & 25-Apr-82 & & 4.8 & & \\
\hline Woahink & Citizen Lake Watch & $02-$ May- 82 & & 4.6 & & \\
\hline Woahink & Citizen Lake Watch & 13-May-92 & & 4.4 & & \\
\hline Woahink & Citizen Lake Watch & 19-May-92 & & 4.1 & & \\
\hline Woahink & Citizen Lake Watch & 26-May-92 & & 7.7 & & \\
\hline Woahink & Citizen Lake Watch & 02-Jun-82 & & 8.7 & & \\
\hline Woahink & Citizen Lake Watch & 17-Jun-82 & & 5.5 & & \\
\hline Woahink & Daggett and Petersen 1093 & 24-Jun-92 & 0 & 6.8 & 0.6200 & -0.478 \\
\hline Woahink & Daggett and Potersen 1903 & 24-Jun-92 & 1 & & 0.4000 & -0.916 \\
\hline Woanink & Daggett and Potersen 1983 & 24-Jun-92 & 2 & & 0.3000 & -1.204 \\
\hline Woahink & Daggett and Petersen 1923 & 24-Jun-02 & 3 & & 0.2500 & -1.386 \\
\hline Woahink & Daggett and Petersen 1993 & 24-Jun-92 & 4 & & 0.1700 & -1.772 \\
\hline Woahink & Deggett and Petersen 1893 & 24 Jun -92 & 5 & & 0.1200 & -2.120 \\
\hline Woahink & Daggett and Petersen 1903 & 24-Jun-82 & 6 & & 0.1000 & .2 .303 \\
\hline Woahink & Daggett and Petersen 1993 & 24Jun-92 & 7 & & 0.0840 & -2.477 \\
\hline
\end{tabular}




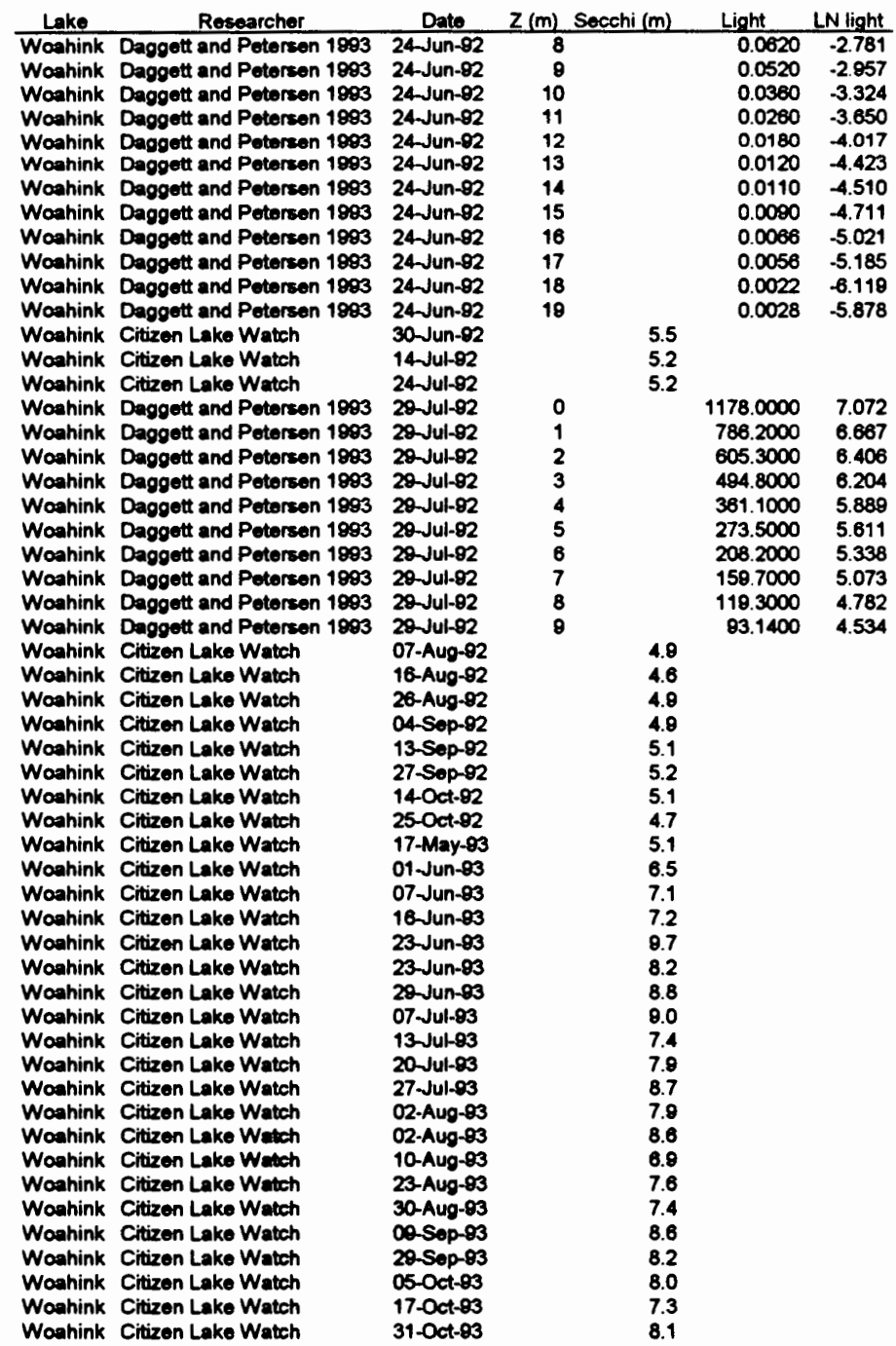


APPENDIX C

NUTRIENTS 


\begin{tabular}{|c|c|c|c|c|c|c|c|c|}
\hline Lake & Researcher & Date & $\begin{array}{c}\text { Depth } \\
\text { (m) }\end{array}$ & $\begin{array}{c}\text { Ammonia } \\
{[\mathrm{NH} 3-\mathrm{N}]} \\
(\mathrm{mg} / \mathrm{L})\end{array}$ & $\begin{array}{c}\text { Nitrate } \\
\text { [NO3-N] } \\
(\mathrm{mg} / \mathrm{L})\end{array}$ & $\begin{array}{c}\text { Total N } \\
{[\mathrm{NT}]} \\
(\mathrm{mg} / \mathrm{L})\end{array}$ & $\begin{array}{c}\text { Total P } \\
{[\mathrm{PT}]} \\
(\mathrm{mg} / \mathrm{L})\end{array}$ & $\begin{array}{c}\text { SRP } \\
\text { [PO4-P] } \\
(\mathrm{mg} / \mathrm{L})\end{array}$ \\
\hline Mercer & Kavanaugh 1973 & 14-Fob-71 & 0 & & & & 0.011 & \\
\hline Mercer & Kavanaugh 1973 & 22-Mar-71 & 0 & & & & 0.006 & \\
\hline Mercer & Kavanaugh 1973 & 12-Jun-71 & 0 & & & & 0.004 & \\
\hline Mercer & Kavanaugh 1973 & 29-Jun-71 & 0 & & & & 0.006 & \\
\hline Mercer & Larson 1974 & 12-Jun-72 & 0 & 0.030 & 0.380 & & & $<.01$ \\
\hline Mercer & Larson 1974 & 21-Aug-72 & 0 & 0.030 & $<.03$ & & & $<.01$ \\
\hline Mercer & Larson 1974 & $30-$ Oct-72 & 0 & 0.190 & 0.170 & & & 0.020 \\
\hline Mercer & Bryant 1979 & 25-Sep-78 & 1 & & 0.120 & & 0.053 & \\
\hline Mercer & Bryant 1979 & 25-Sep-78 & 11 & & 0.110 & & 0.355 & \\
\hline Mercer & Bryant 1979 & 15-Feb-79 & 1 & & 1.400 & & 0.021 & \\
\hline Mercer & Bryant 1979 & 15-Jun-79 & 1 & & 0.750 & & 0.063 & \\
\hline Mercer & Bryant 1979 & 15-Jun-79 & 10 & & 0.940 & & 0.290 & \\
\hline Mercer & Bryant 1979 & 15-Aug-79 & 1 & & 0.300 & & 0.064 & \\
\hline Mercer & Bryant 1979 & 15-Aug-79 & 9 & & 0.070 & & 0.102 & \\
\hline Mercer & Johnson et al. 1985 & 18-Jul-81 & $0-5$ & & & & 0.030 & \\
\hline Mercer & Johnson et al. 1985 & $02-$ May-82 & $0-4.2$ & & & & 0.013 & \\
\hline Mercer & Johnson ot al. 1985 & $19-$ Nov-82 & $0-4$ & & & & 0.035 & \\
\hline Mercer & Sweet $1990 \mathrm{a}$ & 06-Jul-89 & 0 & & & & 0.025 & \\
\hline Mercer & Sweet 1990a & 06-Jul-89 & 10 & & & & 0.037 & \\
\hline Mercer & Sweet 1990a & 06-Jul-89 & $0-10$ & 0.030 & 0.510 & 0.40 & 0.025 & $<.003$ \\
\hline Mercer & Swoet 1990a & 24-Sep-89 & $0-6.8$ & $<.01$ & 0.070 & 0.29 & 0.044 & $<.003$ \\
\hline Mercer & Daggett and Petersen 1993 & 24-Jun-92 & 0 & & & & 0.020 & \\
\hline Mercer & Daggett and Petersen 1993 & 29-Jul-92 & 0 & & & & 0.020 & \\
\hline Munsel & Kavanaugh 1973 & 19-Apr-71 & 0.5 & & & & 0.012 & \\
\hline Munsel & Kavanaugh 1973 & 18-May-71 & 0.5 & & & & 0.003 & \\
\hline Munsel & Kavanaugh 1973 & 11-Jun-71 & 0.5 & & & & 0.005 & \\
\hline Munsel & Kavanaugh 1973 & 28-Jun-71 & 0.5 & & & & 0.005 & \\
\hline Munsel & Kavanaugh 1973 & 29-Jun-71 & 0.5 & & & & 0.005 & \\
\hline Munsel & Larson 1974 & 03-Apr-73 & 1 & $<.01$ & 0.120 & 0.20 & 0.200 & $<.01$ \\
\hline Munsel & Larson 1974 & 03-Apr-73 & 21 & 0.030 & 0.140 & 0.30 & 0.200 & 0.010 \\
\hline Munsel & Larson 1974 & 11-Jun-73 & 1 & 0.020 & 0.050 & $<.1$ & $<.1$ & 0.010 \\
\hline Munsel & Larson 1974 & 11-Jun-73 & 21 & 0.150 & 0.220 & 0.20 & 0.100 & $<.01$ \\
\hline Munsel & Larson 1974 & 27-Aug-73 & 2 & 0.030 & $<.01$ & 0.30 & 0.100 & $<.01$ \\
\hline Munsel & Larson 1974 & 27-Aug-73 & 21 & 0.100 & 0.040 & 0.30 & 0.100 & $<.01$ \\
\hline Munsel & Bryant 1979 & 26-Sep-78 & 1 & 0.060 & 0.030 & 0.20 & 0.013 & $<.001$ \\
\hline Munsel & Bryant 1979 & 26-Sep-78 & 11 & & 0.010 & & & 0.160 \\
\hline Munsel & Bryant 1979 & 15-Feb-79 & 1 & & 0.100 & & & 0.012 \\
\hline Munsel & Bryant 1979 & 15-Feb-79 & 7 & & 0.100 & & & 0.013 \\
\hline Munsel & Bryant 1979 & 15-Jun-79 & 1 & & 0.030 & & & 0.015 \\
\hline Munsel & Bryant 1979 & 15-Jun-79 & 7 & & 0.100 & & & 0.040 \\
\hline Munsel & Bryant 1979 & 15-Aug-79 & 1 & & 0.010 & & & 0.092 \\
\hline Munsel & Bryant 1979 & 15-Aug-79 & 8 & & 0.010 & & & 0.102 \\
\hline Munsel & Johnson ot al. 1985 & 20-Jul-81 & $0-9.4$ & & & & 0.014 & \\
\hline Munsel & Johnson et al. 1985 & $01-$ May-82 & $0-8$ & & & & 0.005 & \\
\hline Munsel & Johnson ot al. 1985 & $19-N o v-82$ & $0-9.6$ & & & & 0.017 & \\
\hline Munsel & Daggett and Petersen 1993 & 23-Jun-92 & 0 & & & & 0.010 & \\
\hline Munsel & Daggett and Petersen 1993 & 28-Jul-92 & 0 & & & & $<.01$ & \\
\hline Woahink & Maloney 1972 & 20-Oct-70 & 0.5 & $<.01$ & 0.024 & 0.40 & 0.006 & 0.001 \\
\hline Woahink & Larson 1974 & 12-Jun-72 & 0 & 0.021 & 0.090 & & & 0.030 \\
\hline Woahink & Larson 1974 & 21-Aug-72 & 0 & 0.060 & 0.070 & & & $<.01$ \\
\hline Woahink & Larson 1974 & $30-0 c t-72$ & 0 & 0.040 & 0.210 & & & $<.01$ \\
\hline Woahink & Bryant 1979 & 15-Feb-79 & 1 & & 0.100 & & & 0.099 \\
\hline Woahink & Bryant 1979 & 15-Fob-79 & 7 & & 0.100 & & & 0.012 \\
\hline Woahink & Bryant 1979 & 15-Jun-79 & 1 & & 0.140 & & & 0.012 \\
\hline Woahink & Bryant 1979 & 15-Jun-79 & 8 & & 0.050 & & & 0.013 \\
\hline Woahink & Bryant 1979 & 15-Aug-79 & 1 & & 0.030 & & & 0.038 \\
\hline Woahink & Bryant 1979 & 15-Aug-79 & 14 & & 0.070 & & & 0.048 \\
\hline Woahink & Johnson et al. 1985 & 28-Jul-81 & $0-11.6$ & & & & 0.004 & \\
\hline Woahink & Johnson et al. 1985 & $02-$ May-82 & $0-10$ & & & & 0.002 & \\
\hline Woahink & Johnson et al. 1985 & $20-N o v-82$ & $0-9.4$ & & & & 0.013 & \\
\hline Woahink & Swoet $1990 \mathrm{~b}$ & 07-Jul-89 & $0-11.8$ & 0.030 & 0.040 & 0.43 & 0.017 & $<.003$ \\
\hline Woahink & Sweet $1990 \mathrm{~b}$ & 24-Sep-89 & $0-9.8$ & 0.140 & 0.080 & 0.20 & 0.037 & $<.003$ \\
\hline Woahink & Daggett and Petersen 1993 & 24-Jun-92 & 0 & & & & $<.01$ & \\
\hline Woahink & Daggett and Petersen 1993 & 29-Jul-92 & 0 & & & & $<.01$ & \\
\hline
\end{tabular}


APPENDIX D

PHYTOPLANKTON SPECIES LIST 


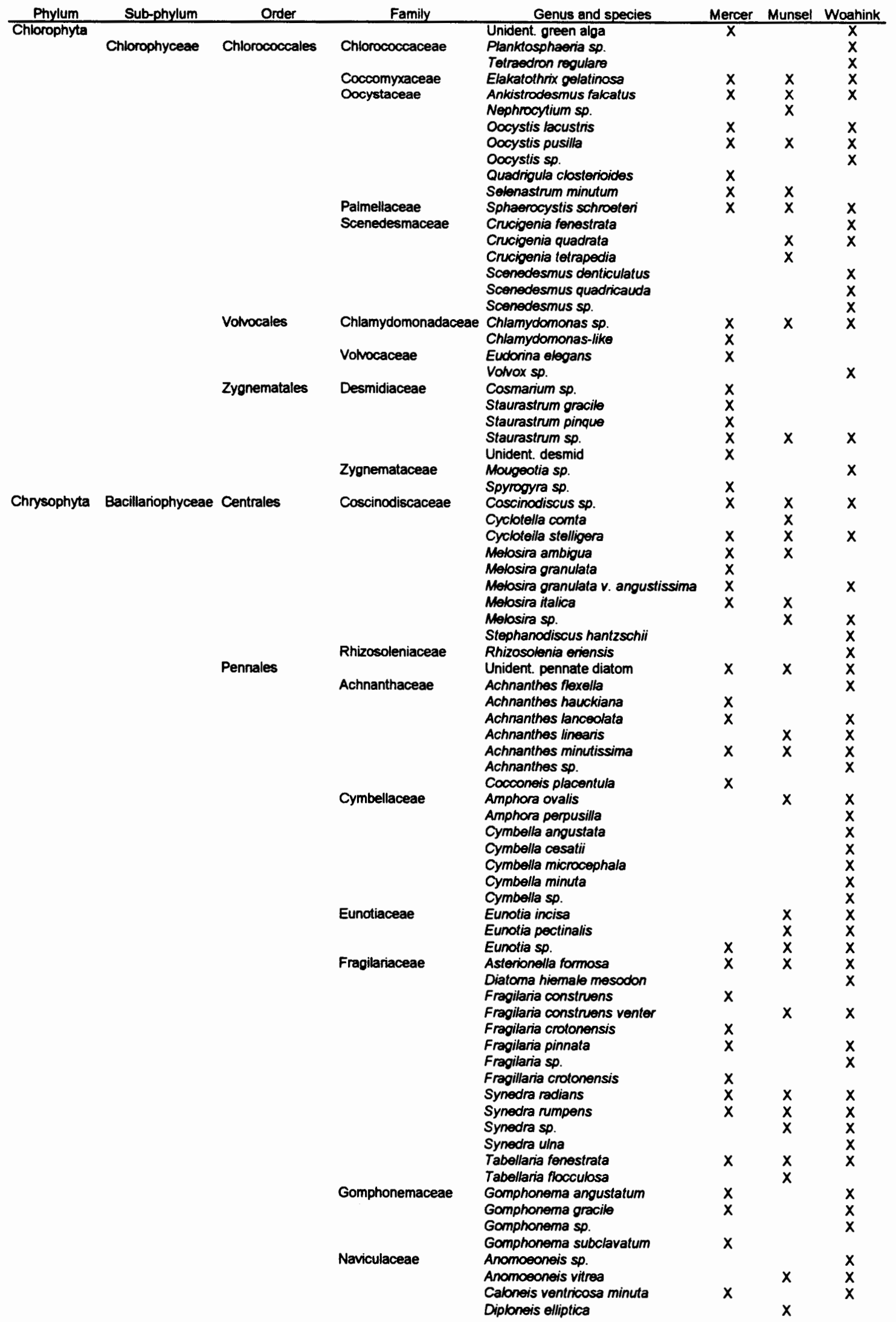




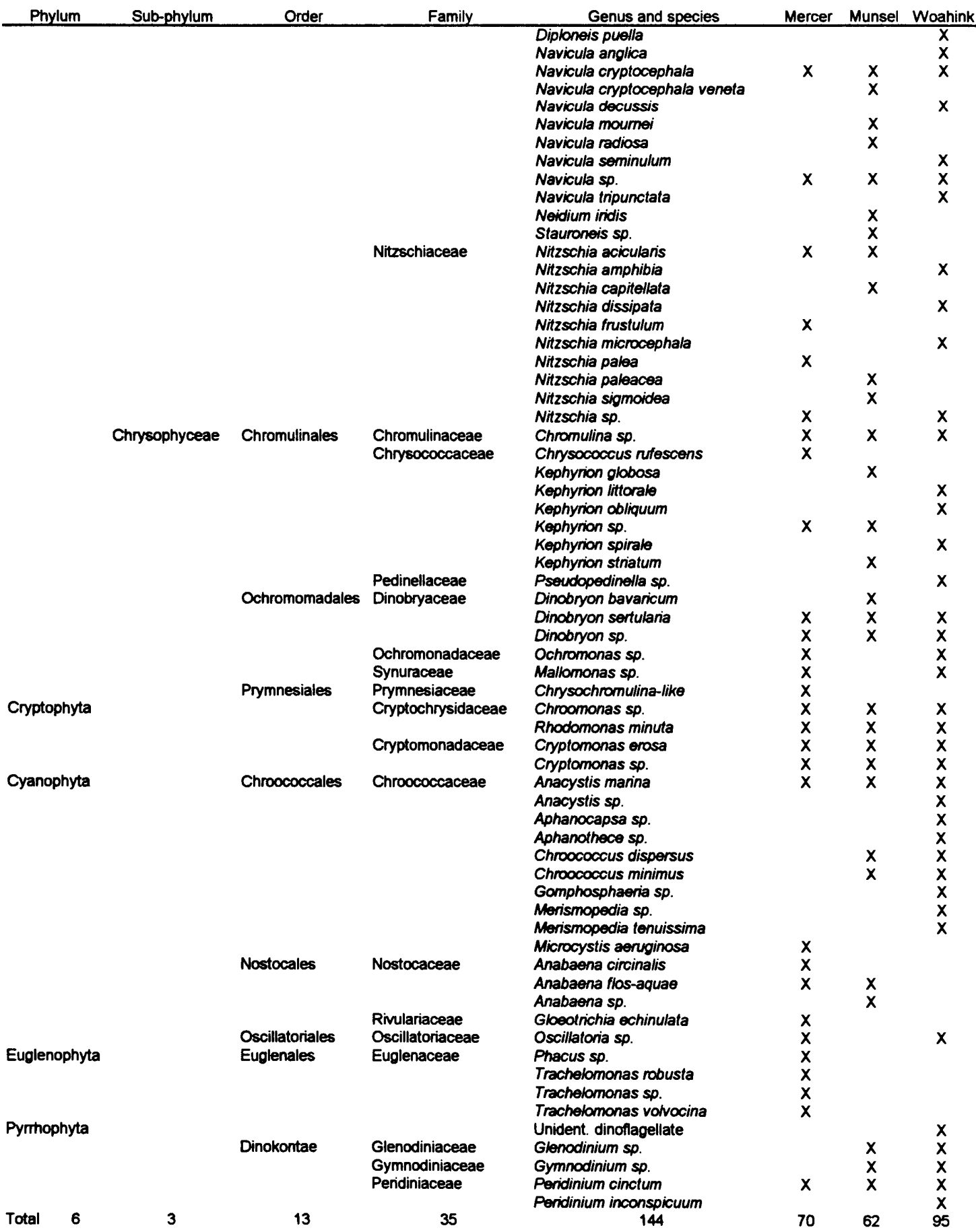




\section{APPENDIX E}

\section{PHYTOPLANKTON BIOVOLUMES AND DENSITIES}




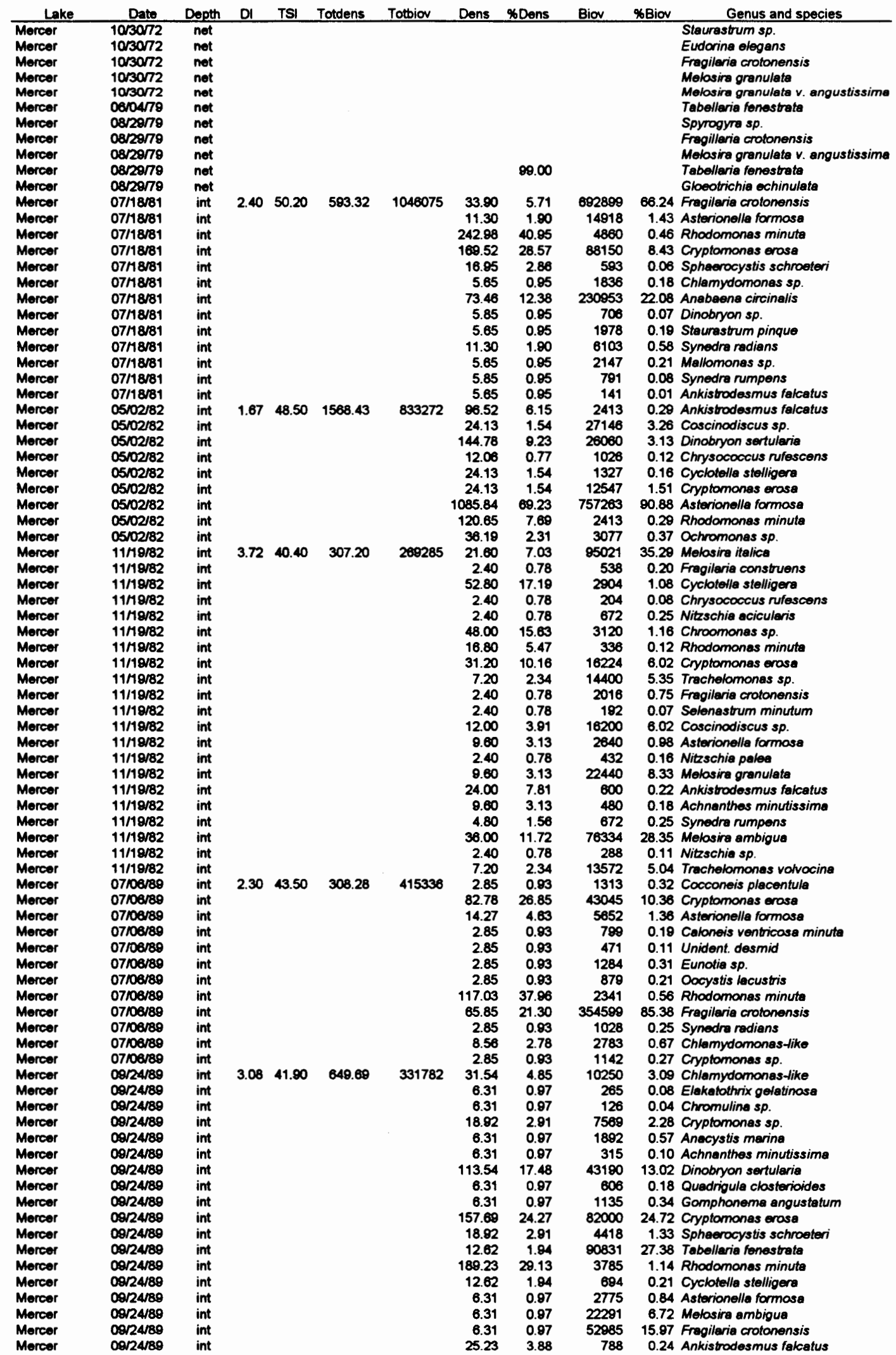

$T S \mid=t r o p h i c$ state index, $\mathrm{O}=5$ Shannon-Weaver diversity index (log base 2), dens=no/mL, biov=cubic microns per $\mathrm{mL}$ 


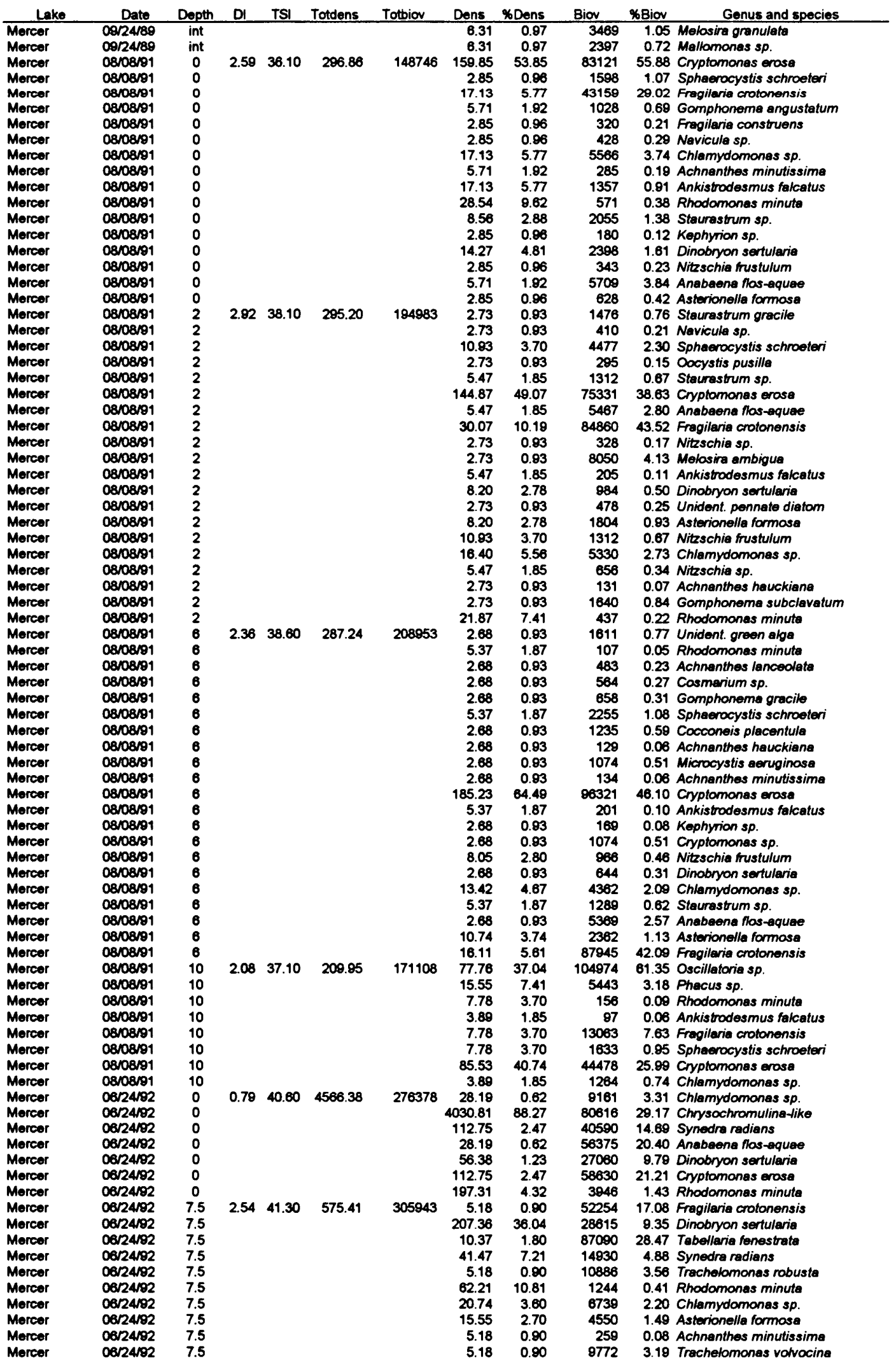

$T S I=t r o p h i c$ state index, $\mathrm{Dl}=$ Shannon-Weaver diversity index (log base 2), dens=no/mL, biovecubic microns per $\mathrm{mL}$ 


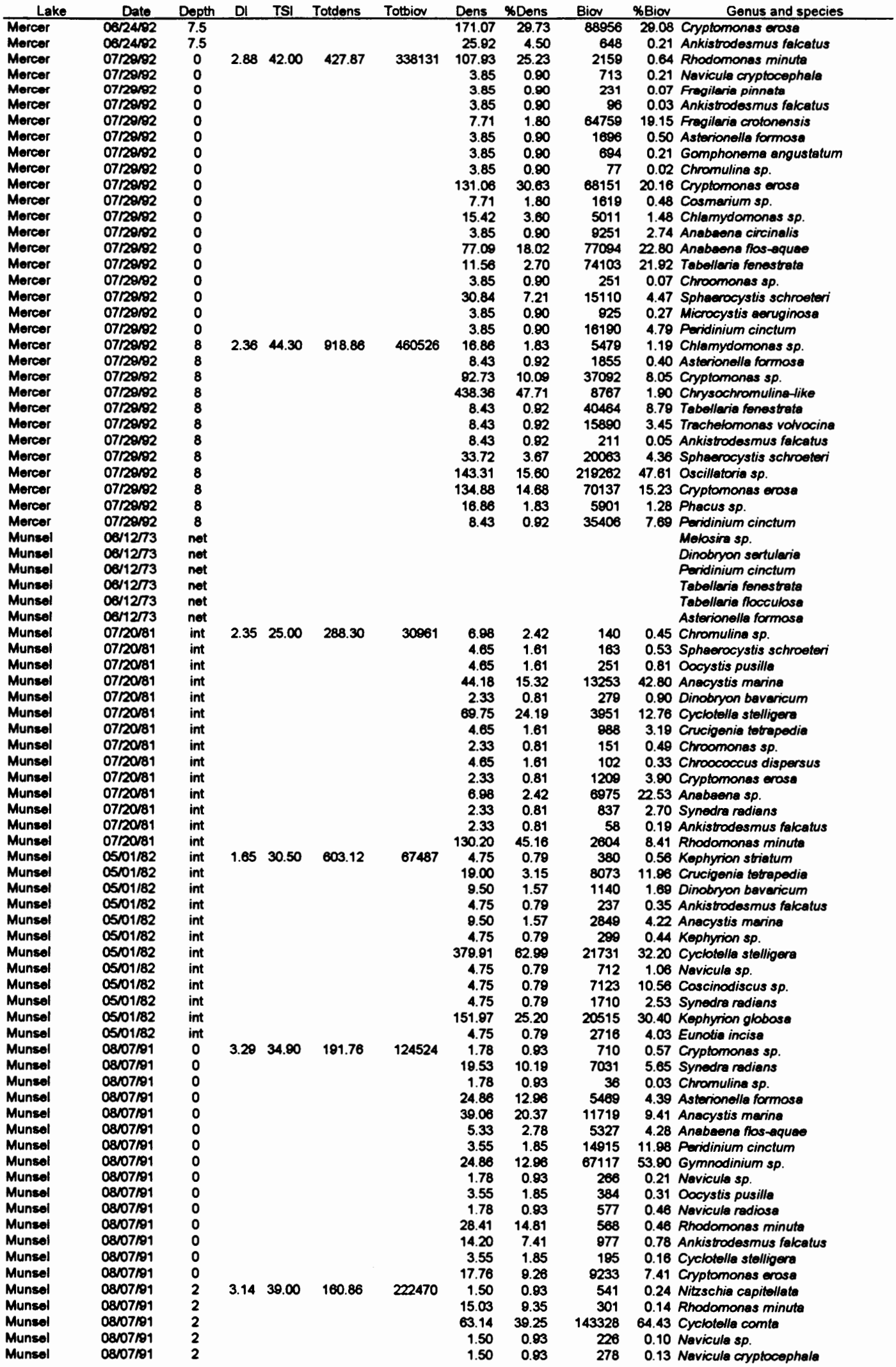

TSI=trophic state index, $\mathrm{D}=$ =Shannon-Weaver diversity index (log base 2), dens=no/mL, biov=cubic microns per $\mathrm{mL}$ 


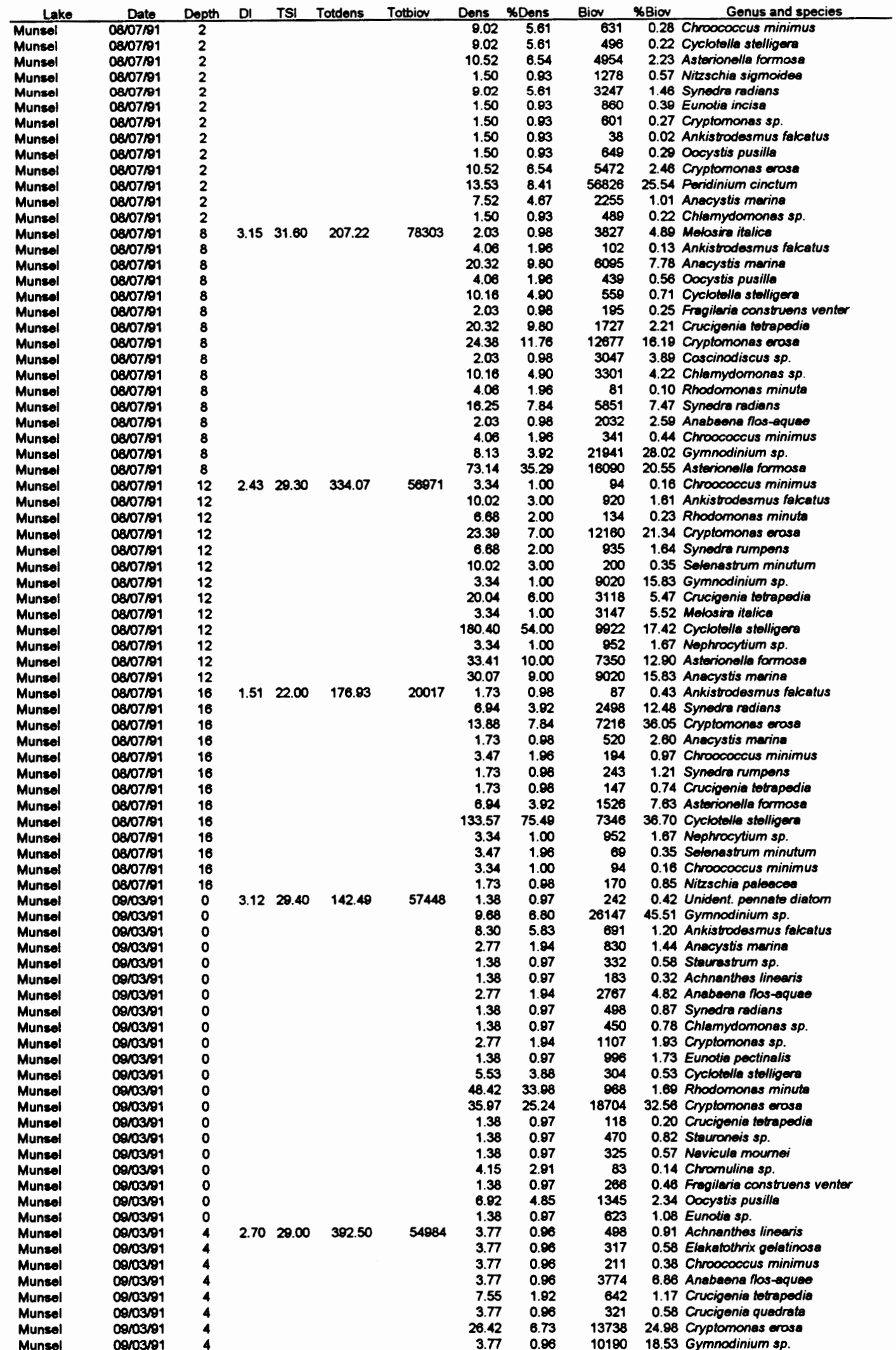

TSI=trophic state index, Dl=Shannon-Woaver diversity index (log base 2), dens=no/mL, biov=cubic microns per $\mathrm{mL}$ 


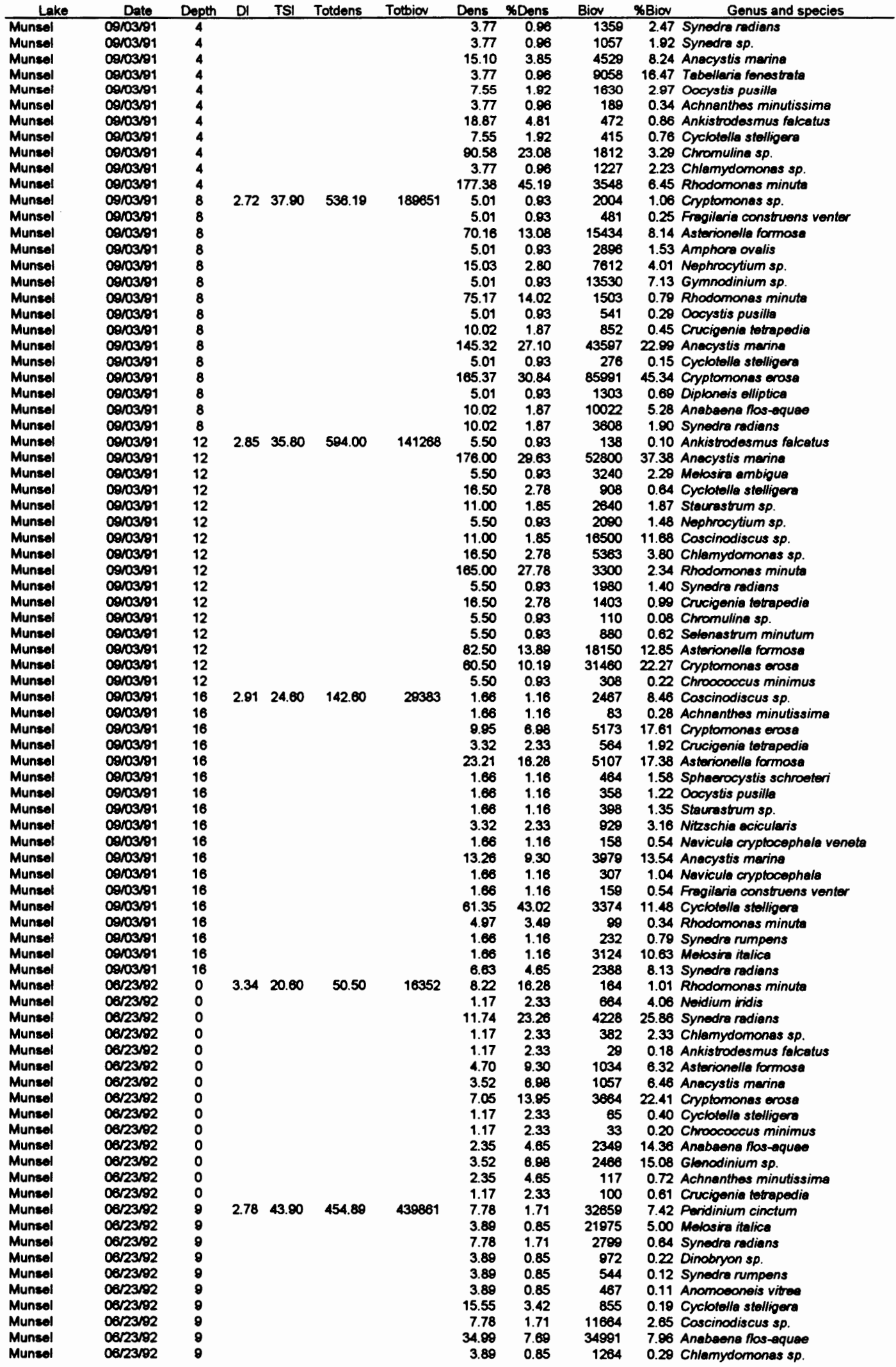

TSI=trophic state index, $\mathrm{Dl}=S$ Shannon-Weaver diversity index (log base 2), dens=no/mL, biov=cubic microns per $\mathrm{mL}$ 


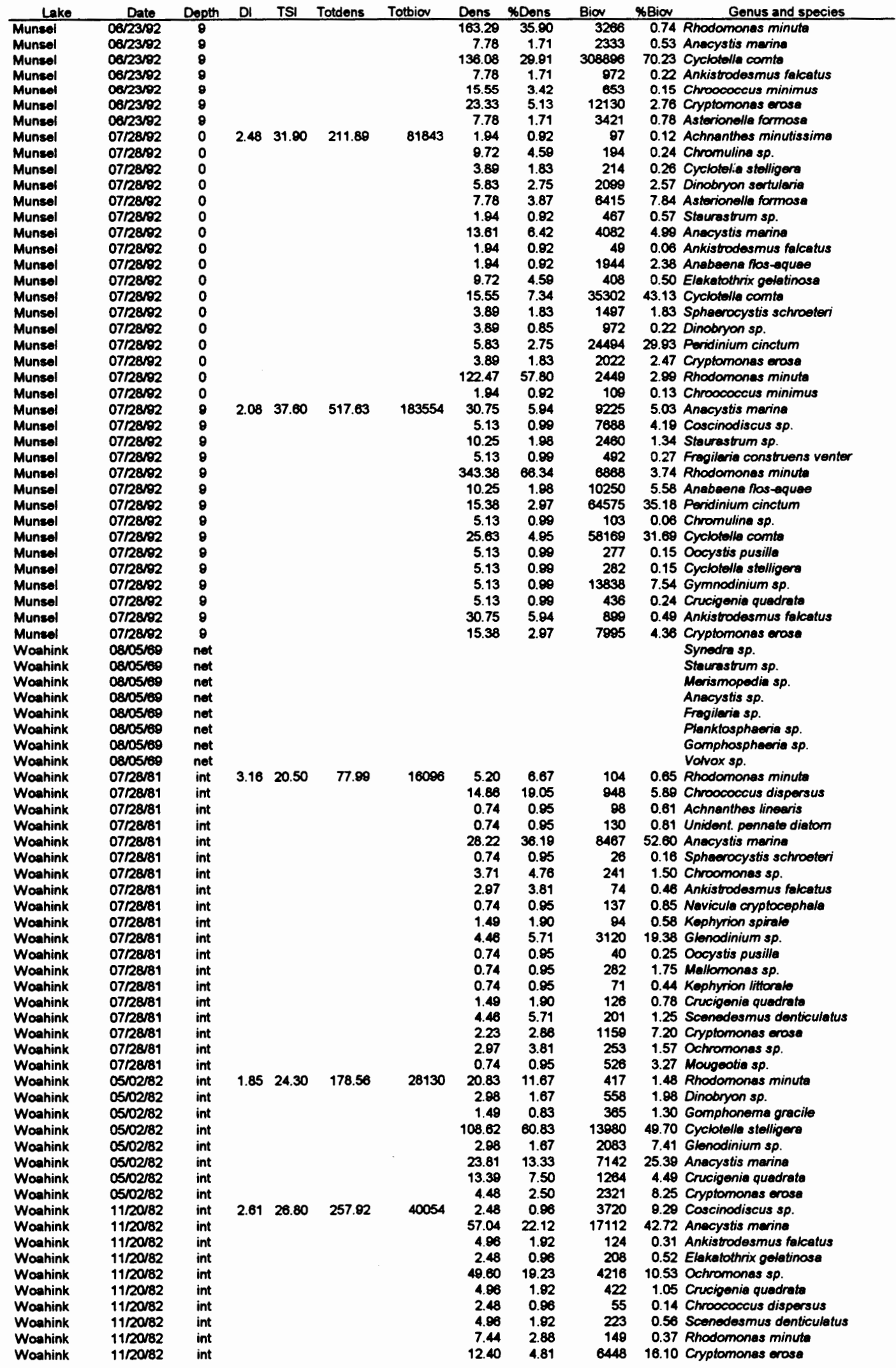

TSl=trophic state index, Dl=Shannon-Weaver diversity index (log base 2), dens=no/mL, biov=cubic microns per $\mathrm{mL}$ 


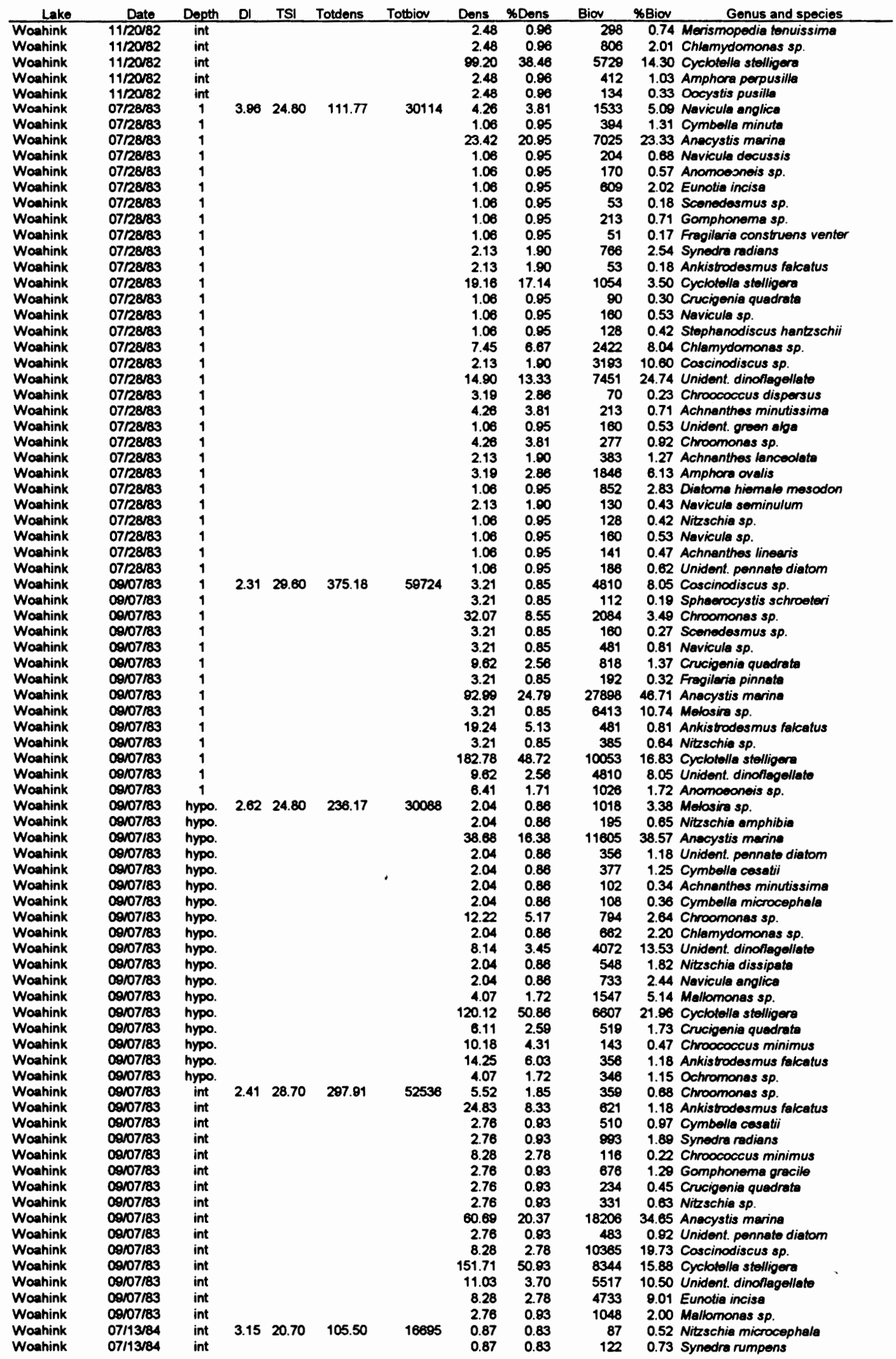

TSI=trophic state index, $\mathrm{Dl}=S$ Shannon-Weaver diversity index (log base 2), dens=no/mL, biov=cubic microns per $\mathrm{mL}$ 


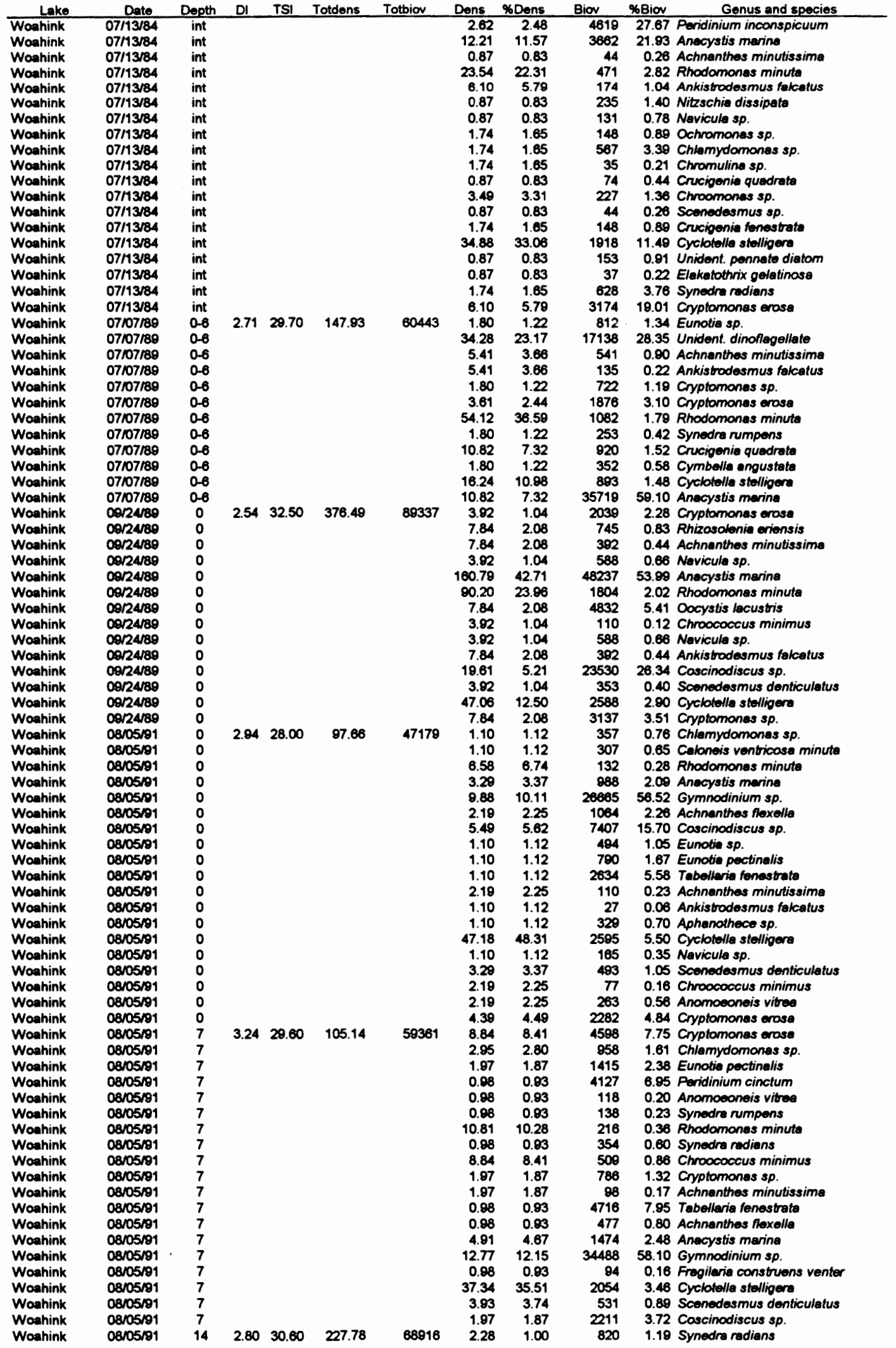

TSt=trophic state index, DI=Shannon-Weaver diversity index (log base 2), dens=no/mL, biovecubic microns per $\mathrm{mL}$ 


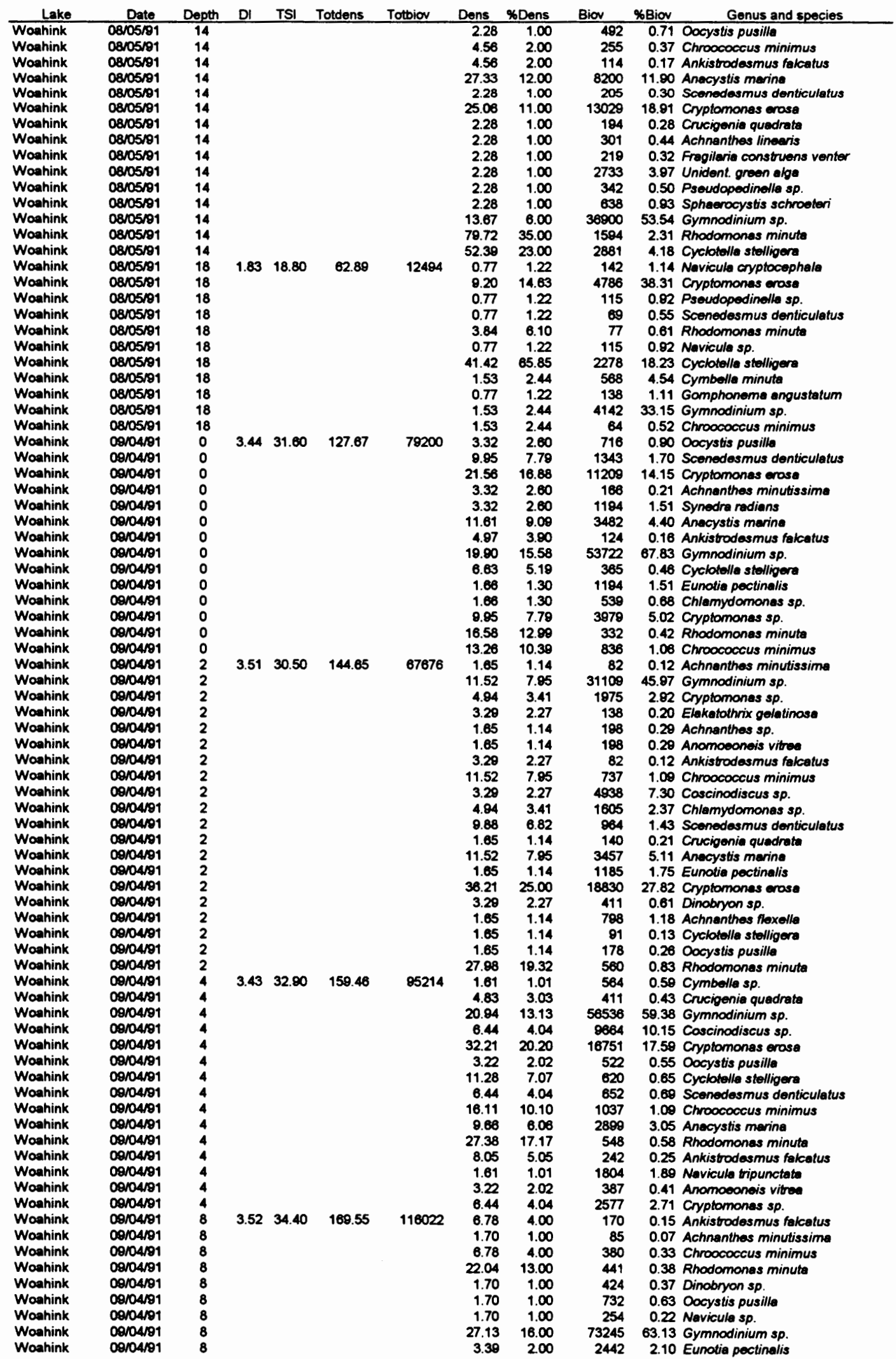

TSt=trophic state index, DI=Shannon-Weaver diversity index (log base 2), dens=no/mL, biov=cubic microns per $\mathrm{mL}$ 


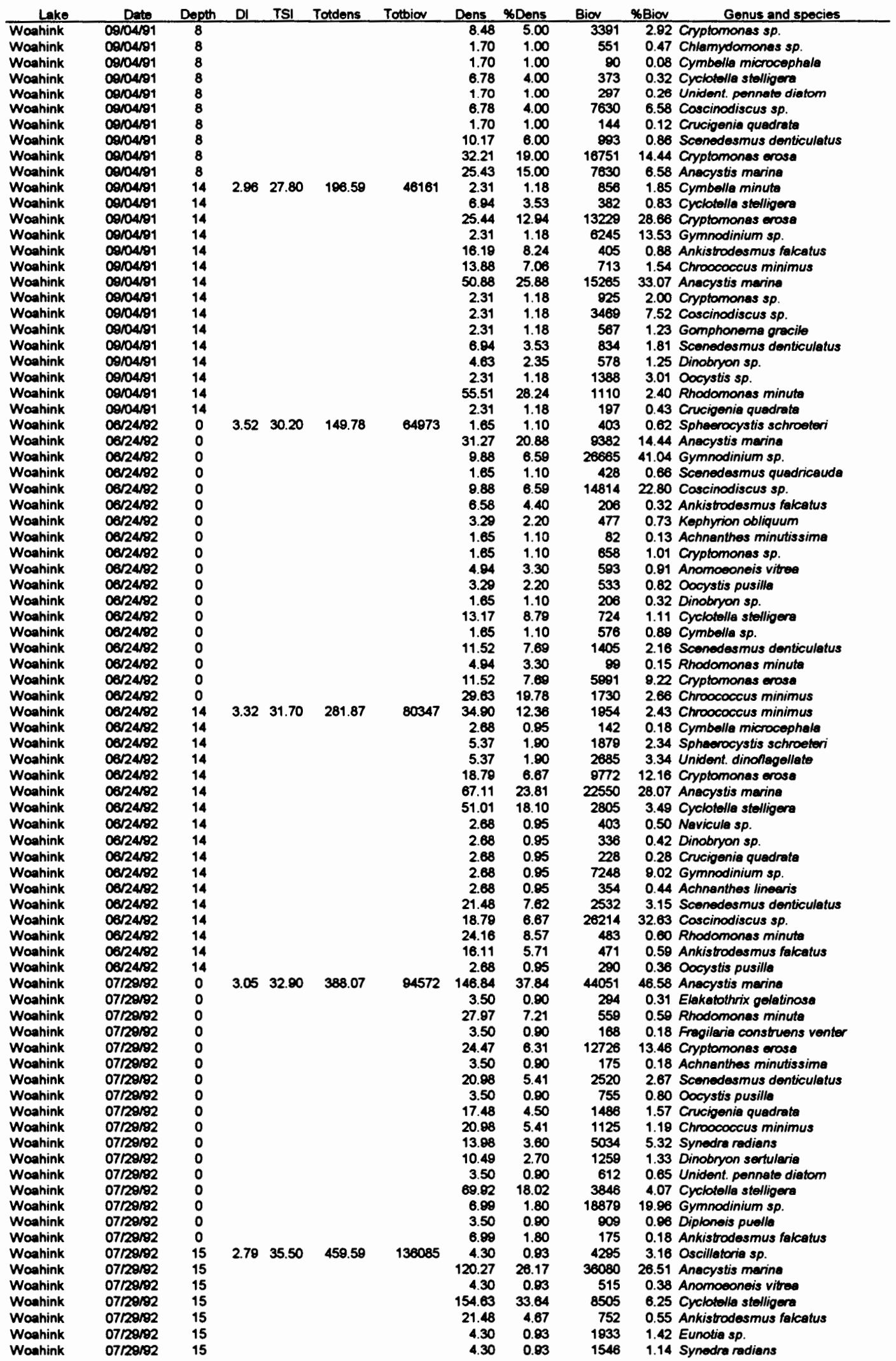

TSI=trophic state index, DI=Shannon-Weaver diversity index (log base 2), dens=no/mL, biov=cubic microns per $\mathrm{mL}$ 


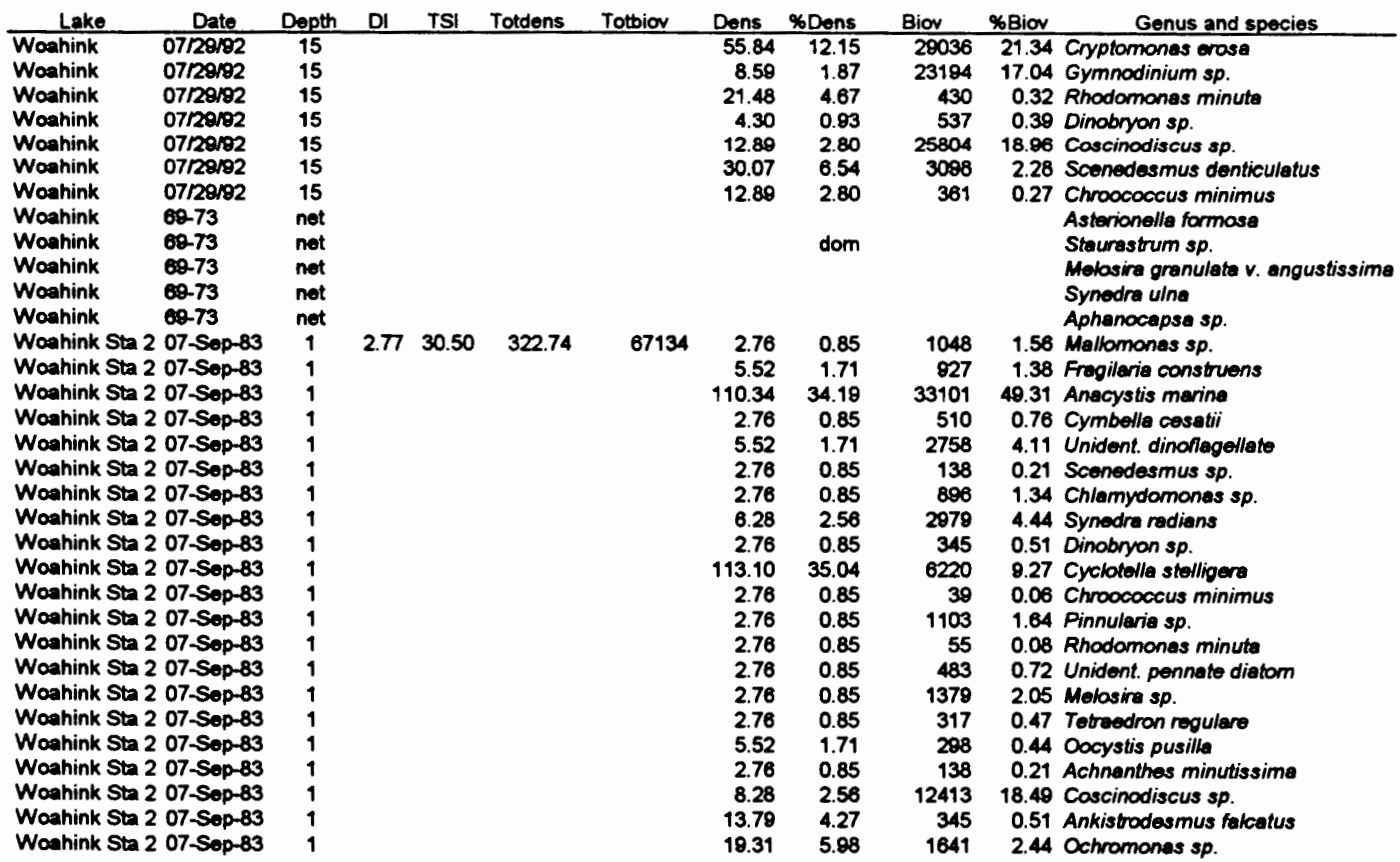


APPENDIX F

ZOOPLANKTON 


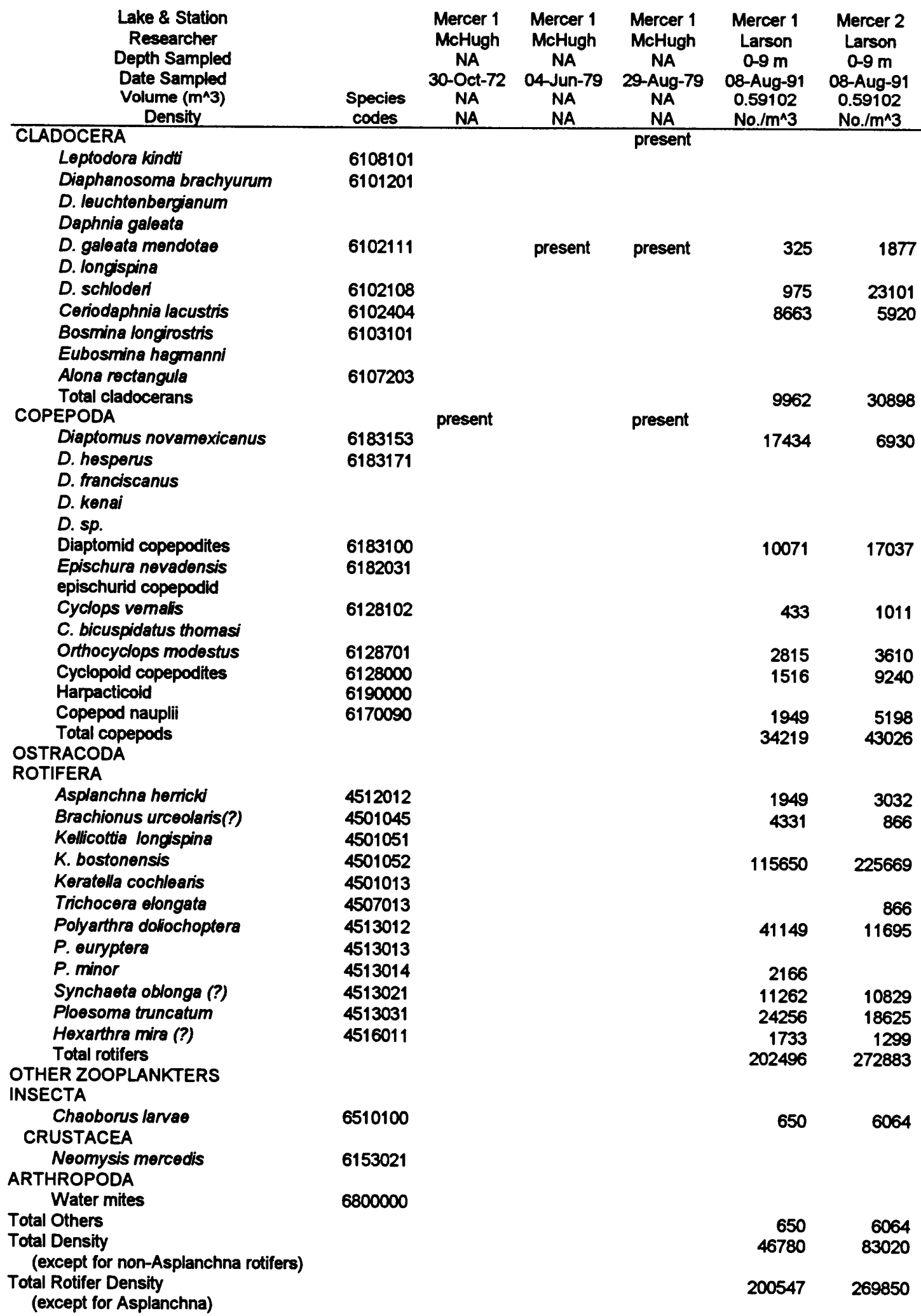




\begin{tabular}{|c|c|c|c|c|c|c|}
\hline $\begin{array}{c}\text { Lake \& Station } \\
\text { Researcher } \\
\text { Depth Sampled } \\
\text { Date Sampled } \\
\text { Volume }\left(m^{\wedge} 3\right) \\
\text { Density }\end{array}$ & $\begin{array}{l}\text { Mercer } 1 \\
\text { Larson } \\
0-10 \mathrm{~m} \\
13-\text { Sep-91 } \\
0.65669 \\
\text { No./m^3 } \\
\end{array}$ & $\begin{array}{l}\text { Munsel } 1 \\
\text { McHugh } \\
\text { 12-Jun-73 } \\
\text { NA } \\
\text { NA } \\
\end{array}$ & $\begin{array}{l}\text { Munsel } 1 \\
\text { Larson } \\
0-8 \mathrm{~m} \\
07-\text { Aug-91 } \\
0.52535 \\
\text { No./m^3 }\end{array}$ & $\begin{array}{l}\text { Munsel } 1 \\
\text { Larson } \\
0-16 \mathrm{~m} \\
07-\text { Aug-91 } \\
1.05071 \\
\text { No./m^3 } \\
\end{array}$ & $\begin{array}{c}\text { Munsel } 2 \\
\text { Larson } \\
0-8 \mathrm{~m} \\
07-\text { Aug-91 } \\
0.52535 \\
\text { No./m^3 }\end{array}$ & $\begin{array}{l}\text { Munsel } 1 \\
\text { Larson } \\
0-7 \mathrm{~m} \\
03-\mathrm{Sep}-91 \\
0.45969 \\
\text { No./m^3 } \\
\end{array}$ \\
\hline \multicolumn{7}{|l|}{ CLADOCERA } \\
\hline Leptodora kinoti & 49 & & & & & \\
\hline $\begin{array}{l}\text { Diaphanosoma brachyurum } \\
\text { D. leuchtenbergianum } \\
\text { Daphnia galeata }\end{array}$ & & & 11329 & 10842 & 7634 & 16521 \\
\hline $\begin{array}{l}\text { D. galeata mendotee } \\
\text { D. longispina }\end{array}$ & 292 & & 4914 & 3046 & 3952 & 4734 \\
\hline D. schloderi & 195 & & & & & \\
\hline Ceriodaphnia lacustris & 780 & & & & & \\
\hline $\begin{array}{l}\text { Bosmina longirostris } \\
\text { Eubosmina hagmanni } \\
\text { Alona rectangula }\end{array}$ & 1364 & & & 244 & & 464 \\
\hline $\begin{array}{l}\text { Total cladocerans } \\
\text { COPEPODA }\end{array}$ & 2680 & & 16243 & 14131 & 11587 & 21719 \\
\hline Diaptomus novamexicanus & 4191 & & 2558 & 5908 & 6226 & 10767 \\
\hline $\begin{array}{l}\text { D. hesperus } \\
\text { D. franciscanus } \\
\text { D. kenai } \\
\text { D. sp. }\end{array}$ & & & 325 & 731 & & \\
\hline $\begin{array}{l}\text { Diaptomid copepodites } \\
\text { Epischura nevadensis } \\
\text { epischurid copepodid }\end{array}$ & 13352 & & $\begin{array}{r}650 \\
81\end{array}$ & $\begin{array}{r}1888 \\
183\end{array}$ & 650 & $\begin{array}{r}8354 \\
93\end{array}$ \\
\hline $\begin{array}{l}\text { Cyclops vemalis } \\
\text { C. bicuspidatus thomasi }\end{array}$ & 682 & & 487 & 2071 & 433 & 928 \\
\hline Orthocyclops modestus & 3898 & & & & & \\
\hline $\begin{array}{l}\text { Cyclopoid copepodites } \\
\text { Harpacticoid }\end{array}$ & 8284 & & 1056 & 4386 & 2003 & 3713 \\
\hline $\begin{array}{l}\text { Copepod nauplii } \\
\text { Total copepods }\end{array}$ & $\begin{array}{l}31089 \\
61496\end{array}$ & & $\begin{array}{r}772 \\
5929\end{array}$ & $\begin{array}{r}1096 \\
16263\end{array}$ & $\begin{array}{r}596 \\
9908\end{array}$ & $\begin{array}{r}3156 \\
27010\end{array}$ \\
\hline $\begin{array}{l}\text { OSTRACODA } \\
\text { ROTIFERA }\end{array}$ & & & & & & \\
\hline $\begin{array}{l}\text { Asplanchna herrickt } \\
\text { Brachionus urcoolanis(?) }\end{array}$ & $\begin{array}{r}3216 \\
780\end{array}$ & & & & & \\
\hline $\begin{array}{l}\text { Kelicottia longispina } \\
\text { K. bostonensis }\end{array}$ & 17055 & present & 41 & 122 & 433 & 835 \\
\hline $\begin{array}{l}\text { Keratella cochiearis } \\
\text { Trichocera elongata }\end{array}$ & $\begin{array}{r}390 \\
97\end{array}$ & present & 41 & & & 650 \\
\hline Polyarthra doliochoptera & 1462 & & 41 & & & \\
\hline P. euryptera & & & 122 & 122 & 217 & 278 \\
\hline P. minor & 487 & & & & & \\
\hline Synchaeta oblonga (?) & 2242 & & & & & \\
\hline Ploesoma truncatum & 54284 & & 81 & 305 & 487 & \\
\hline Hexarthra mira (?) & 2924 & & 41 & & 54 & \\
\hline $\begin{array}{l}\text { Total rotifers } \\
\text { OTHER ZOOPLANKTERS } \\
\text { INSECTA }\end{array}$ & 82937 & & 365 & 548 & 1191 & 1764 \\
\hline $\begin{array}{l}\text { Chaoborus larvae } \\
\text { CRUSTACEA }\end{array}$ & 1072 & & & & & \\
\hline $\begin{array}{l}\text { Neomysis mercedis } \\
\text { ARTHROPODA } \\
\text { Water mites }\end{array}$ & & & & 4 & & \\
\hline $\begin{array}{l}\text { Total Others } \\
\text { Total Density } \\
\quad \text { (except for non-Asplanchna rotifers) }\end{array}$ & $\begin{array}{r}1072 \\
68464\end{array}$ & & $\begin{array}{r}0 \\
22172\end{array}$ & $\begin{array}{r}4 \\
30638\end{array}$ & $\begin{array}{r}0 \\
21495\end{array}$ & $\begin{array}{r}0 \\
48729\end{array}$ \\
\hline $\begin{array}{l}\text { Total Rotifer Density } \\
\text { (except for Asplanchna) }\end{array}$ & 79721 & & 365 & 548 & 1191 & 1764 \\
\hline
\end{tabular}




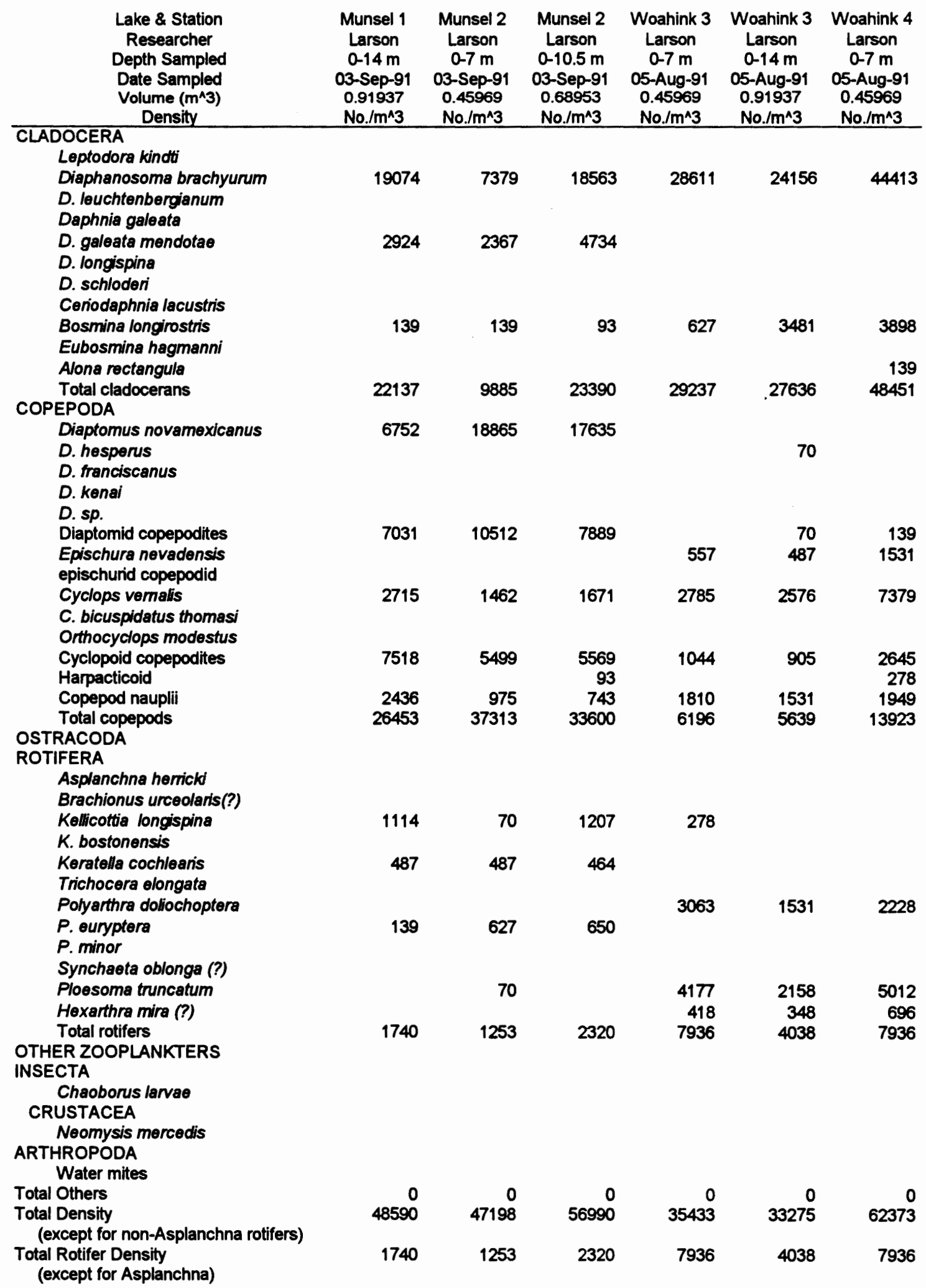




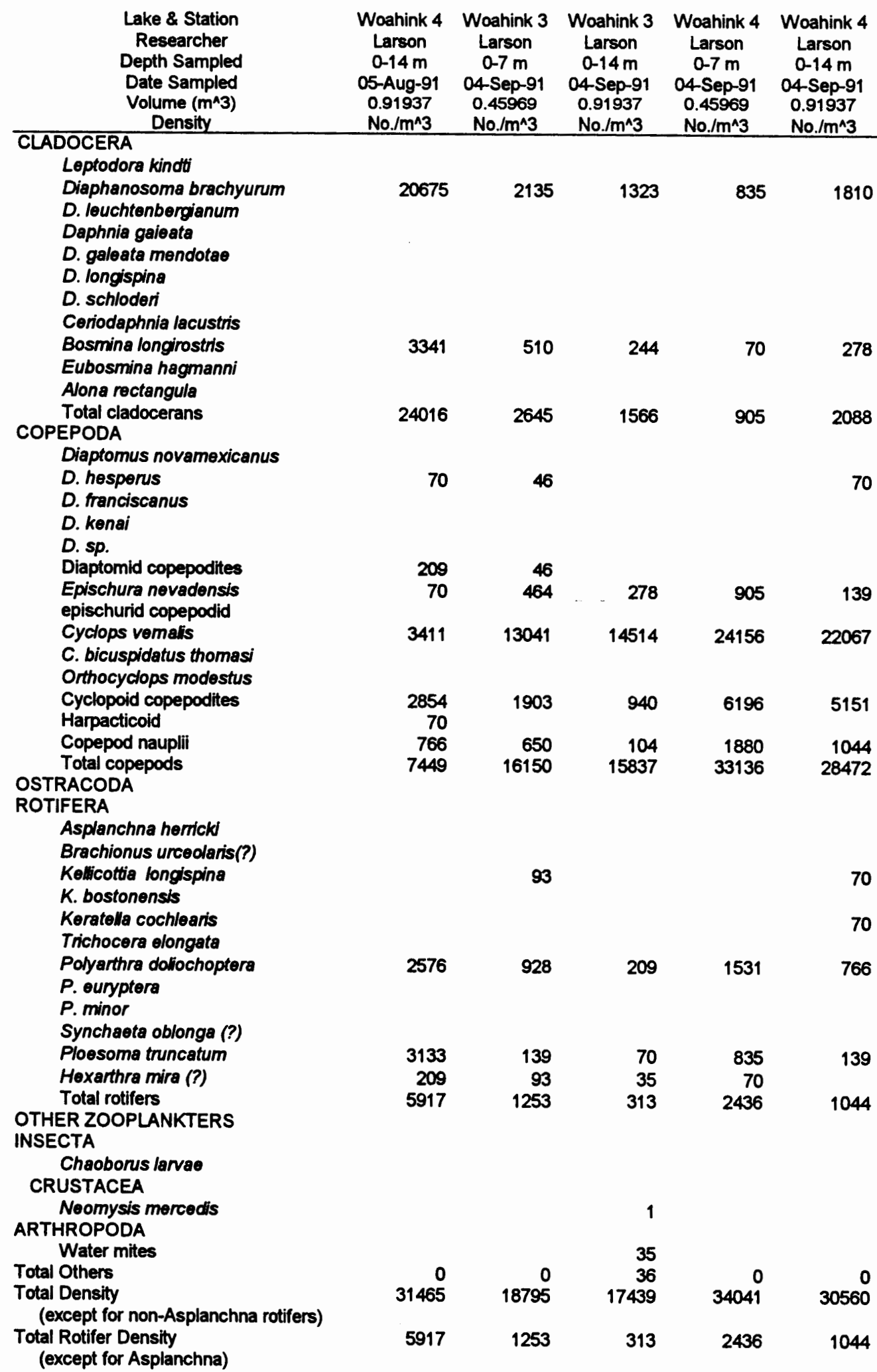


APPENDIX G

BENTHIC INVERTEBRATES 


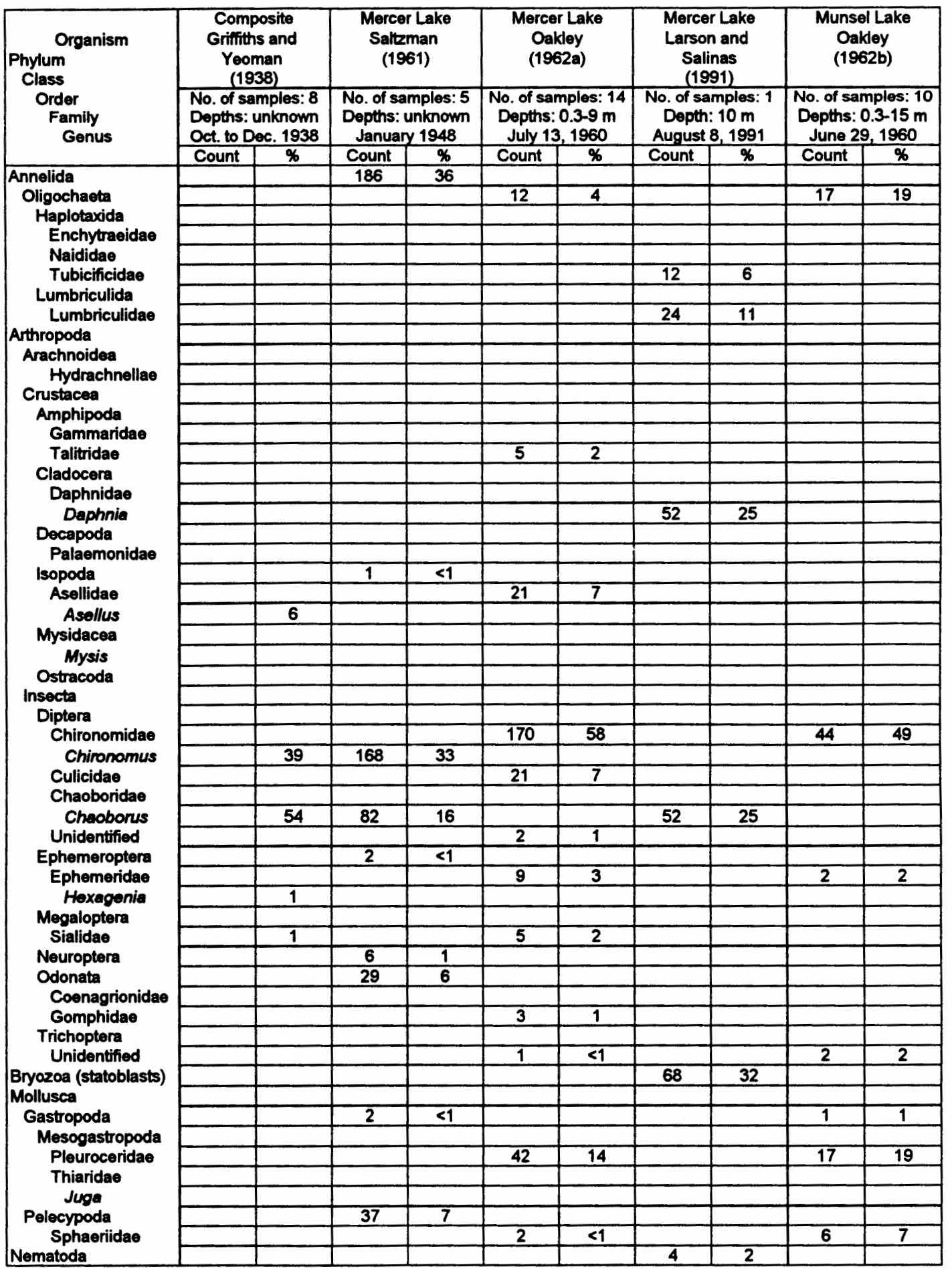




\begin{tabular}{|c|c|c|c|c|c|c|c|c|c|c|}
\hline \multirow{3}{*}{$\begin{array}{l}\text { Organism } \\
\text { Phylum } \\
\text { Class } \\
\text { Order } \\
\text { Family } \\
\text { Genus }\end{array}$} & \multirow{2}{*}{\multicolumn{2}{|c|}{ 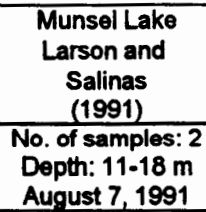 }} & \multirow{2}{*}{\multicolumn{2}{|c|}{$\begin{array}{l}\text { Woahink Lake } \\
\text { Gritiths and } \\
\text { Yeoman } \\
\text { (1938) } \\
\text { No. of samples: } 10 \\
\text { Depths: unknown } \\
\text { Aug. to Oct. } 1938\end{array}$}} & \multicolumn{2}{|c|}{$\begin{array}{l}\text { Woahink Lake } \\
\text { Saltzman } \\
(1962)\end{array}$} & \multicolumn{2}{|c|}{$\begin{array}{c}\text { Woahink Lake } \\
\text { McGie and } \\
\text { Breuser } \\
\text { (1962) }\end{array}$} & \multicolumn{2}{|c|}{$\begin{array}{l}\text { Woahink Lake } \\
\text { Larson and } \\
\text { Salinas } \\
\text { (1991) }\end{array}$} \\
\hline & & & & & $\begin{array}{l}\text { No. of } 5 \\
\text { Depths } \\
\text { Nov. to }\end{array}$ & $\begin{array}{l}\text { les: } 22 \\
\text { known } \\
1947\end{array}$ & $\begin{array}{c}\text { No. of s } \\
\text { Depths } \\
\text { July }\end{array}$ & $\begin{array}{l}\text { ples: } 14 \\
.3-9 \mathrm{~m} \\
1960\end{array}$ & $\begin{array}{l}\text { No. of s } \\
\text { Dept } \\
\text { Augus }\end{array}$ & $\begin{array}{l}\text { ples: } 1 \\
6 \mathrm{~m} \\
1991\end{array}$ \\
\hline & Count & $\%$ & Count & $\overline{\%}$ & Count & $\%$ & Count & $\%$ & Count & $\%$ \\
\hline \multirow{9}{*}{\begin{tabular}{|l|} 
Annelida \\
Oligochaeta \\
Haplotaxida \\
Enchytraeidae \\
Naididae \\
Tubicificidae \\
Lumbriculida \\
Lumbriculidae \\
Arthropoda
\end{tabular}} & & & & & 25 & 5 & & & & \\
\hline & & & & & & & 12 & 20 & & \\
\hline & & & & & & & & & & \\
\hline & & & & & & & & & 8 & 9 \\
\hline & 8 & 2 & & & & & & & & \\
\hline & 108 & 31 & & & & & & & 8 & 9 \\
\hline & & & & & & & & & & \\
\hline & 80 & 23 & & & & & & & & \\
\hline & & & & & & & & & & \\
\hline \multirow{3}{*}{$\begin{array}{l}\text { Arachnoidea } \\
\text { Hydrachnellae } \\
\text { Crustacea }\end{array}$} & & & & & & & & & & \\
\hline & & & & & 2 & $<1$ & & & & \\
\hline & & & & & & & & & & \\
\hline \multirow{3}{*}{$\begin{array}{l}\text { Amphipoda } \\
\text { Gammaridae } \\
\text { Talitridae }\end{array}$} & & & & & 110 & 23 & & & & \\
\hline & & & & & 21 & 4 & & & & \\
\hline & & & & & & & 19 & 32 & & \\
\hline Cladocera & & & & & & & & & & \\
\hline Daphnidae & & & & & & & & & & \\
\hline \multirow{5}{*}{$\begin{array}{l}\text { Daphnia } \\
\text { Decapoda } \\
\text { Palaemonidae } \\
\text { Isopoda } \\
\text { Asellidao }\end{array}$} & 8 & 2 & & & & & & & & \\
\hline & & & & & & & & & & \\
\hline & 8 & 2 & & & & & & & & \\
\hline & & & & & & & & & & \\
\hline & & & & & & & & & & \\
\hline \multirow{2}{*}{$\begin{array}{l}\text { Asollus } \\
\text { Mysidacea }\end{array}$} & & & & 6 & & & & & & \\
\hline & & & & & & & & & & \\
\hline \multirow{3}{*}{$\begin{array}{c}\text { Mysis } \\
\text { Ostracoda } \\
\text { Insecta }\end{array}$} & & & & & & & 1 & 2 & 32 & 36 \\
\hline & 8 & 2 & & & & & & & & \\
\hline & & & & & & & & & & \\
\hline \multirow{5}{*}{$\begin{array}{l}\text { Diptera } \\
\text { Chironomidae } \\
\text { Chironomus } \\
\text { Culicidae } \\
\text { Chaoboridae }\end{array}$} & & & & & 5 & 1 & & & & \\
\hline & 88 & 26 & & & & & 2 & 3 & 16 & 18 \\
\hline & & & & 39 & 232 & 49 & & & & \\
\hline & & & & & & & & & & \\
\hline & & & & & & & & & & \\
\hline \multirow{3}{*}{$\begin{array}{l}\text { Chaoborus } \\
\text { Unidentified } \\
\text { Ephemeroptera }\end{array}$} & & & & 54 & 1 & $<1$ & & & & \\
\hline & & & & & & & 2 & 3 & & \\
\hline & & & & & 5 & 1 & & & & \\
\hline Ephemeridae & & & & & & & 12 & 20 & & \\
\hline Hexagenia & & & & 1 & & & & & & \\
\hline Megaloptera & & & & & & & & & & \\
\hline Sialidae & & & & 1 & & & 4 & 7 & & \\
\hline Neuroptera & & & & & 15 & 3 & & & & \\
\hline Odonata & & & & & & & & & & \\
\hline Coenagrionidae & & & & & & & 1 & 2 & & \\
\hline Gomphidae & & & & & 3 & 1 & & & & \\
\hline Trichoptera & & & & & & & & & & \\
\hline Unidentified & & & & & & & 4 & 7 & & \\
\hline Bryozoa (statoblasts) & 12 & 4 & & & & & & & & \\
\hline Mollusca & & & & & & & & & & \\
\hline Gastropoda & & & & & 13 & 3 & & & & \\
\hline Mesogastropoda & & & & & & & & & & \\
\hline Pleuroceridae & & & & & & & 3 & 5 & & \\
\hline Thiaridae & & & & & & & & & & \\
\hline Juga & & & & & & & & & 8 & 9 \\
\hline Pelecypoda & & & & & 42 & 9 & & & & \\
\hline Sphaeriidae & 24 & 7 & & & & & & & 16 & 18 \\
\hline Nematoda & & & & & & & & & & \\
\hline
\end{tabular}


APPENDIX $\mathrm{H}$

COMPILATION OF DATA COLLECTED IN 1991 AND 1992 


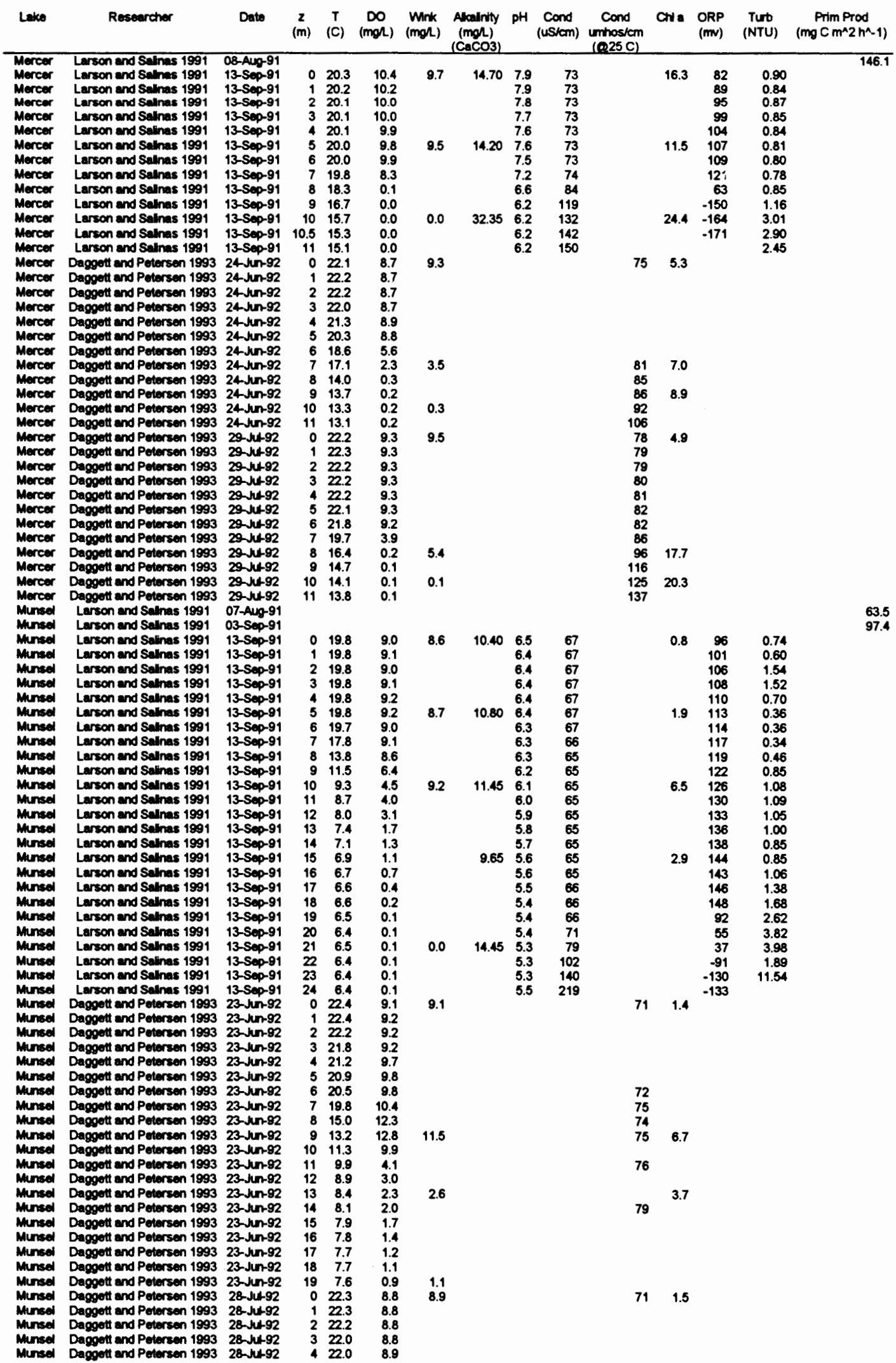

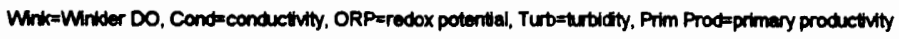




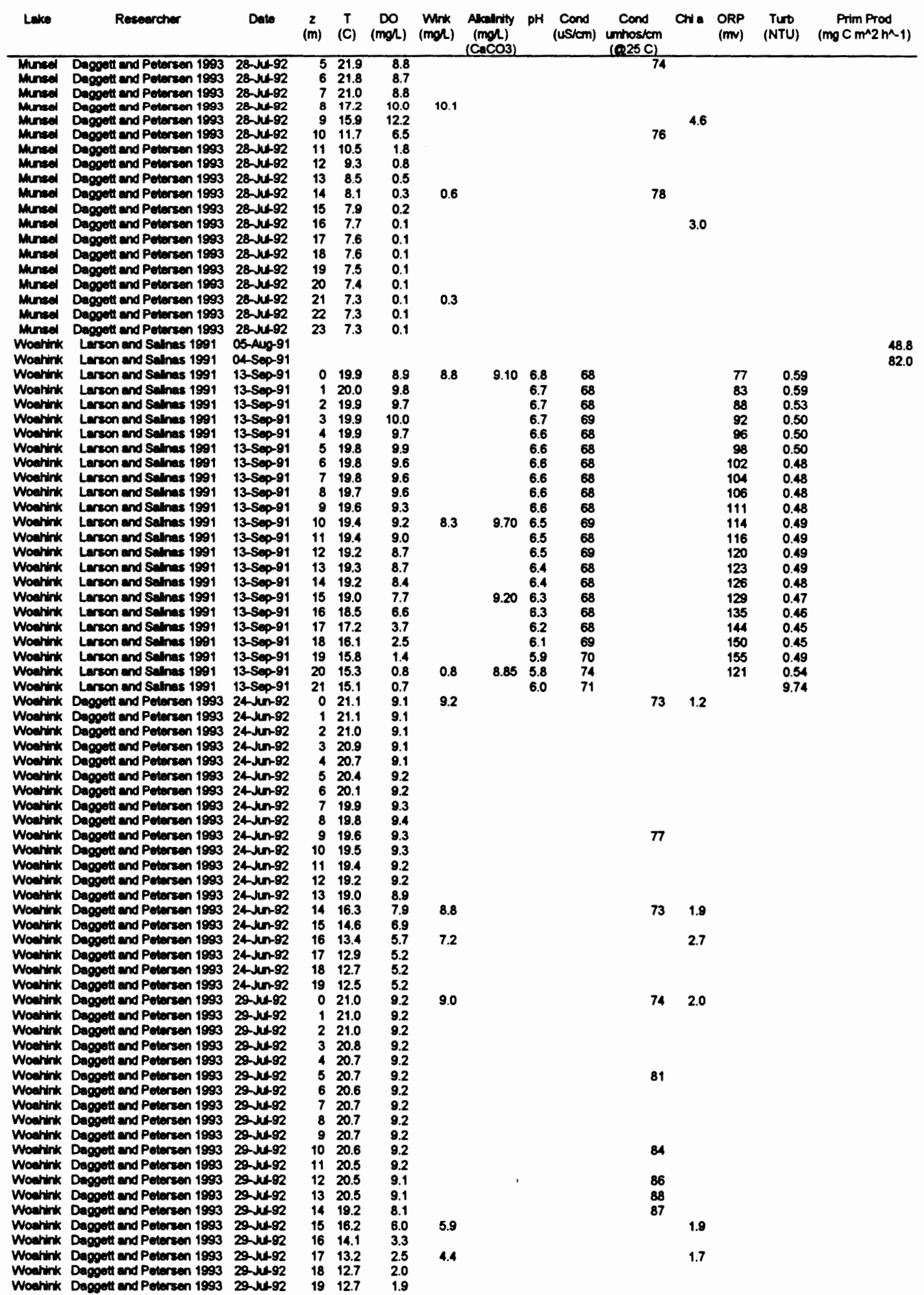

